\title{
Copyright Term Extension and Intellectual Property as Constitutional Property
}

\author{
Paul M. Schwartz ${ }^{\dagger}$ and William Michael Treanor ${ }^{\dagger \dagger}$
}

\section{INTRODUCTION}

Since the ratification of the Constitution, intellectual property law in the United States has always been, in part, constitutional law. Among the enumerated powers that Article I of the Constitution vests in Congress is the power to create certain intellectual property rights.' Yet, until very recently, this Clause and its meaning-and the larger subject of the relationship between constitutional law and intellectual property-received little attention from constitutional law scholars. ${ }^{2}$ In a short period of time,

$\dagger$ Professor, Brooklyn Law School. Berlin Prize Fellow, American Academy in Berlin, Germany (Fall 2002); Transatlantic Fellow, German Marshall Fund, Transatlantic Program, Brussels, Belgium (Spring 2003). Professor Schwartz would like to thank Gary Smith of the American Academy in Berlin as well as Bill Antholis and Bill Drozdiak of the German Marshall Fund for offering stimulating and collegial international environments for scholarship. Finally, Dean Joan Wexler of Brooklyn Law School provided support to Professor Schwartz through the Dean's Research Fund as well as through her encouragement during every stage of this project.

+† Dean, Fordham Law School. From 1998 until 2001, Dean Treanor served as Deputy Assistant Attorney General, Office of Legal Counsel, United States Department of Justice. The views expressed in this Essay do not necessarily represent the views of the Department at that time or at the present.

Earlier versions of this work were presented at the Fordham International Intellectual Property Conference in April 2002 and in Dean Treanor's Fall 2002 Constitutional History class at Fordham. The authors would like to thank the participants and audience at the conference and the class members. We would also like to thank David Barron, Tricia Bellia, Michael Bimhack, Jill Fisch, Martin Flaherty, Jane Ginsburg, Abner Greene, Hugh Hansen, Vicki Jackson, Ted Janger, Sonia Katyal, Marty Lederman, Lance Liebman, Mark Patterson, Peggy Radin, Jocl Reidenberg, Dan Richman, David Saul Schwartz, and Howard Shapiro for their suggestions and comments on this Essay.

1. U.S. CONST. art. I, $\$ 8, \mathrm{cl} .8$ (authorizing Congress to "promote the Progress of Science and useful Arts, by securing for limited Times to Authors and Inventors the exclusive Right to their respective Writings and Discoverics").

2. Thus, the second edition of Laurence Tribe's treatise on constitutional law did not find the Copyright Clause to be one of the three areas of domestic power granted to Congress-commerce, taxing, and spending-that had "provoked sufficient legislation and litigation to generate 
however, as intellectual property has come to play a dramatically larger role in the national economy, ${ }^{3}$ scholars have begun to focus on the Constitution's Copyright Clause. And, to a remarkable extent, they have reached a common position. With striking unanimity, scholars have called for aggressive judicial review of the constitutionality of congressional legislation in this area.

The champions of this position-we refer to them as the "IP Restrictors"-represent a remarkable array of constitutional and intellectual property scholars, including Yochai Benkler, Paul Heald and Suzanna Sherry, Lawrence Lessig, Jessica Litman, Robert Merges and Glenn Reynolds, and William Patry. ${ }^{4}$ Their position appeals to the deepest

significant bodies of constitutional doctrine." LAURENCE H. TRIBE, AMERICAN CONSTITUTIONAL LAW 324 ( 2 d ed. 1988).

3. After enactment of the Sonny Bono Copyright Term Extension Act, Senator Orrin Hatch made this point regarding the importance of intellectual property to the U.S. economy:

America exports more copyrighted intellectual property than any country in the world ... . In fact, in 1996, the core U.S. copyright industries achieved foreign sales and exports exceeding $\$ 60$ billion, surpassing, for the first time, every other export sector, including automotive, agriculture and aircraft. And, according to 1996 estimates, copyright industries account for some 5.7 percent of the total gross domestic product. Furthermore, copyright industries are creating American jobs at nearly three times the rate of other industries, with the number of U.S. workers employed by core copyright industries more than doubling between 1977 and 1996. Today, these industries contribute more to the economy and employ more workers than any single manufacturing sector, accounting for over 5 percent of the total U.S. workforce.

144 CoNG. REC. S12,377 (daily ed. Oct. 12, 1998) (statement of Sen. Hatch).

4. For works that embrace what we call here the IP Restrictors' position, see, for example, LAWRENCE LesSig, THE FUTURE OF IDEAS (2001); JESSICA LiTMAN, Digital COPYRIGHT (2001); Yochai Benkler, Constitutional Bounds of Database Protection: The Role of Judicial Review in the Creation and Definition of Private Rights in Information, 15 BERKELEY TECH. L.J. 535 (2000); Dan T. Coenen \& Paul J. Heald, Means/Ends Analysis in Copyright Law: Eldred v. Ashcroft in One Act, 36 LOY. L.A. L. REV. 99 (2002); Michael H. Davis, Extending Copyright and the Constitution: "Have I Stayed Too Long?," 52 FLA. L. REV. 989 (2000); Paul J. Heald \& Suzanna Sherry, Implied Limits on the Legislative Power: The Copyright Clause as an Absolute Constraint on Congress, 2000 U. ILL. L. REV. 1119; Raymond Shih Ray Ku, The Creative Destruction of Copyright: Napster and the New Economics of Digital Technology, $69 \mathrm{U}$. CHI. L. REV. 263 (2002); Glynn S. Lunney, Jr., The Death of Copyright: Digital Technology, Private Copying, and the Digital Millennium Copyright Act, 87 VA. L. REV. 813 (2001); Robert Patrick Merges \& Glenn Harlan Reynolds, The Proper Scope of the Copyright and Patent Power, 37 HARV. J. ON LEGIS. 45 (2000); William Patry, The Enumerated Powers Doctrine and Intellectual Property: An Imminent Constiutional Collision, 67 GEO. WASH. L. REV. 359 (1999); L. Ray Patterson, Eldred v. Reno: An Example of the Law of Unintended Consequences, 8 J. INTELL. Prop. L. 223 (2001); Malla Pollack, What Is Congress Supposed To Promote?: Defining "Progress" in Article 1, Section 8, Clause 8 of the United States Constitution, or Introducing the Progress Clause, 80 NEB. L. REV. 754 (2001); Stewart E. Sterk, Rhetoric and Reality in Copyright Law, 94 MICH. L. REV. 1197 (1996); Edward C. Walterscheid, Defining the Patent and Copyright Term: Terms Limits and the Copyright Clause, 7 J. INTELL. PrOP. L. 315 (2000); and MARCI A. HAMILTON, THE HISTORICAL AND PHILOSOPHICAL UNDERPINNINGS OF THE Copyright Clause (Cardozo Sch. of Law, Occasional Papers in Intellectual Prop. No. 5), at http://www.cardozo.yu.edu/ip_program/papers/5.pdf (last visited Jan. 28, 2003).

While there have been a few dissenting voices, no previous scholarly work has offered a developed case for deferential review. For examples of dissenting views, see Jane C. Ginsburg et al., The Constitutionality of Copyright Extension: How Long Is Too Long?, 18 CARDOZO ARTS \& ENT L.J. 651 (2000) (including a panel discussion with comments of Professors Arthur Miller and 
convictions of the left; it urges courts to vindicate the interests of the public by overturning legislation that favors the naked self-interest of moneyed elites. This position also appeals to the deepest convictions of the right; it builds on cases such as the Commerce Clause decisions of Morrison ${ }^{5}$ and Lopez ${ }^{6}$ in urging courts to read narrowly another of the Constitution's grants of power to Congress.

In this Term's Eldred v. Ashcroft, ${ }^{7}$ leading IP Restrictor Lawrence Lessig, representing petitioner Eric Eldred, sought to convince the Supreme Court that the IP Restrictors' view of the Copyright Clause was the correct one. At issue in Eldred was the constitutionality of the Sonny Bono Copyright Term Extension Act (CTEA). ${ }^{8}$ The CTEA extends by twenty years the period of copyright protection both for new works and for already existing works, and Eldred argued that the Copyright Clause bars Congress from increasing copyright protection of works already created. From a commercial perspective, the retrospective aspect of the statute has enormous consequences. At the time of the statute's passage, a number of iconic works were on the cusp of entering the public domain, the most prominent being early films starring Mickey Mouse. Indeed, Lessig termed the statute the "Mickey Mouse Protection Act." Harvard Law School's Berkman Center for Internet and Society, with which Lessig brought the case, stated the matter even more tersely on its website: "Free the Mouse."10

By a vote of 7-2, the Supreme Court rejected Eldred's claim and upheld the statute. ${ }^{11}$ But while the Court rejected the IP Restrictors' vision, it did not offer a satisfactory competing conception of the Copyright Clause and

Wendy Gordon in support of the Copyright Term Extension Act's constitutionality); Shira Perlmutter, Participation in the International Copyright System as a Means To Promote the Progress of Science and the Useful Arts, 36 LOY. L.A. L. REV. 323 (2002) (arguing that international intellectual property concerns are relevant to construction of the Copyright Clause); and Kevin D. Galbraith, Note, Forever on the Installment Plan?: An Examination of the Constitutional History of the Copyright Clause and Whether the Copyright Term Extension Act of 1998 Squares with the Founders' Intent, 12 FORDHAM INTELL. PROP. MEDIA \& ENT. L.J. 1119 , 1148-49 (2002) (arguing that the Founders' broad support for federal copyright suggests that the Copyright Term Extension Act is constitutional).

5. United States v. Morrison, 529 U.S. 598 (2000).

6. United States v. Lopez, 514 U.S. 549 (1995).

7. 123 S. Ct. 769 (2003).

8. Sonny Bono Copyright Term Extension Act, Pub. L. No. 105-298, tit. I, 112 Stat. 2827 (1998).

9. Doug Bedell, Professor Says Disney, Other Firms Typify What's Wrong with Copyrights, DALlas MORNING NEWS, Mar. 14, 2002, at 3D.

10. Berkman Ctr. for Internet \& Soc'y, Harvard Law Sch., Openlaw: Eldred v. Ashcroft, at http://eon.law.harvard.edu/openlaw/eldredvashcroft (last visited Feb. 3, 2003). The Berkman Center website is a valuable source of information about this litigation.

11. Eldred, $123 \mathrm{~S}$. Ct. at 775 . In addition to his claim that the CTEA ran afoul of the Copyright Clause, Eldred also argued that the statute violated the First Amendment. The Court treated this claim as relatively insubstantial and rejected it, observing that "when, as in this case, Congress has not altered the traditional contours of copyright protection, further First Amendment scrutiny is unnecessary." Id. at 790. 
how the courts should construe it. Critically, even though the standard of review was of central significance, the Court applied a deferential form of rational basis scrutiny of the congressional legislation without explaining why this was the appropriate standard. Thus, while embracing deferential review, the Court did not make the case for it.

The purpose of this Essay is to develop the case for deferential review and, at a deeper level, to offer a new paradigm for understanding the Copyright Clause. We hope that this paradigm will influence future case law. The Essay's basic insight is that from the vantage point of constitutional law, intellectual property should be treated as a form of constitutional property. Deference to congressional judgments is warranted because congressional legislation affecting intellectual property is best understood as analytically similar to congressional legislation affecting other forms of property. ${ }^{12}$ Courts subject congressional legislation affecting traditional forms of property to deferential review because of concerns about institutional competence and respect for majoritarian decisionmaking. These two concerns in conjunction with proper regard for holistic constitutional interpretation should also lead courts to deferential review of congressional legislation affecting intellectual property. ${ }^{13}$

In developing our position, we draw on constitutional history and, in particular, on the lessons of Lochner v. New York. ${ }^{14}$ In defense of their vision of the Constitution, the IP Restrictors and the dissenters in Eldred make claims about the original understanding that, to an astonishing extent, echo those made by proponents of Lochner-era jurisprudence. Informed by the historical critique of Lochner-era jurisprudence, this Essay argues that the originalist claims of the IP Restrictors fail for the same two reasons that the claims of Lochner's defenders failed. In arguing for active judicial review, the IP Restrictors and the dissenters disregard the limited scope of judicial review at the time of the Founding. Additionally, in arguing that the Founders were deeply fearful of any monopolies and that they therefore must have given Congress only a very limited power to create intellectual property rights, the IP Restrictors and the dissenters disregard the range of views among the Founders about monopolies.

Lochner also suggests a further critique of the IP Restrictors' claims and of the Eldred dissenters' constitutional approach. Lochner can be understood as an act in a drama that has repeatedly taken place in our nation's history when the economy has undergone fundamental change.

12. See infra Part V.

13. In this Essay, our discussion focuses on copyright, rather than patents, since copyright protection was at issue in Eldred and has been central to the academic controversies. The arguments made here concerning judicial competence, political process concerns, and the Founders' views on economic regulation are, however, largely applicable in the patent context as well.

14. 198 U.S. 45 (1905). 
This drama has three acts: (1) a legislative response to economic change, (2) an activist judicial review of the legislative response, and (3) a judicial retreat. This process occurred in the nineteenth century as business corporations emerged. It occurred once again in the late nineteenth and early twentieth century with the rise of the modern business corporation. Indeed, Lochner is best understood as part of the stage-two reaction to the rise of the modern business corporation. It occurred, again, in the late twentieth century with the arrival of the welfare state.

Eldred might have been the third millennium's Lochner. Lessig, as part of his Eldred challenge, highlighted the fact that the economy was undergoing fundamental change and pointed to the arrival of the Internet as making copyright law of central importance. ${ }^{15}$ Justice Breyer, in his Eldred dissent, even argued that economic change made heightened review necessary. ${ }^{16}$ Had the petitioners prevailed in Eldred, the case would have constituted the second-stage opinion that followed the development of the Internet economy. ${ }^{17}$

The Supreme Court avoided this trap. Rather than creating a Lochner for this new moment of economic transformation, the Eldred Court adopted a deferential stance of judicial review. We seek here to offer a justification for why this is the right result.

Part II begins by setting out the policy proposals of the IP Restrictors. It then shows how the IP Restrictors transformed their normative vision into a constitutional one. We will highlight the originalist claims of the IP Restrictors and discuss their methodology; in the absence of traditional types of originalist evidence supporting their positions, the IP Restrictors instead invoke broad abstractions. Part III then discusses Eldred itself and the various opinions.

The next two Parts build on the lessons of Lochner. Part IV presents our originalist challenge to the originalist claims of the IP Restrictors and

15. See Petition for Certiorari at 9, Eldred (No. 01-618) (noting that CTEA will block "an extraordinary range of creative invention" from falling into the public domain "just at the time that the Internet is enabling a much broader range of individuals to draw upon and develop this creative work").

16. See Eldred, $123 \mathrm{~S}$. Ct. at 812 (Breyer, J., dissenting) ("[V]igilance is all the more necessary in a new Century that will see the intellectual property rights and the forms of expression that underlie them play an ever more important role in the Nation's economy and the lives of its Citizens.").

17. Although the idea of an Internet economy is not uncontested, a consensus is emerging that the Information Age and the Internet are having a transformative impact on society. For works examining different aspects of these changes, see FRANCES CAIRNCROSS, THE DEATH OF Distance: How THE COMMUNICATIONS REVOlution WILl ChaNGE OUR LiVES (1997); MANUEL CASTELLS, THE INTERNET GALAXY: REFLECTIONS ON THE INTERNET, BUSINESS, AND SOCIETY (2001); THE INTERNET UPHEAVAL: RAISING QUESTIONS, SEEKING ANSWERS IN COMMUNICATIONS POLICY (Ingo Vogelsang \& Benjamin M. Compaine eds., 2000); and CARL SHAPIRO \& HAL R. VARIAN, INFORMATION RULES: A STRATEGIC GUIDE TO THE NETWORK ECONOMY (1999). 
the Eldred dissenters. In particular, it focuses on their claim that consistency with the original understanding demands that the Supreme Court strike down the CTEA's retrospective extension of copyright protection. Part V then develops the larger historical point that although courts have consistently responded to economic change by making new assertions of judicial power, to do so in Eldred would have been a mistake. Thus, these two concluding Parts argue that the policy vision advanced by the IP Restrictors and underlying Eldred's arguments is not one that the Founders would have thought constitutionally mandated, and therefore not one that the Court should have constitutionally mandated. More broadly, Parts IV and V develop our claim that the appropriate judicial stance in reviewing congressional legislation under the Copyright Clause is one of deference.

\section{THE IP RESTRICTORS' VISION}

The U.S. Constitution gives Congress the power " $[\mathrm{t}] \mathrm{o}$ promote the Progress of Science and useful Arts, by securing for limited Times to Authors and Inventors the exclusive Right to their respective Writings and Discoveries." ${ }^{\prime 18}$ Like numerous constitutional texts, these few words lead to innumerable debates. Is the Preamble-"to promote the Progress of Science and useful Arts"- hortatory or legally binding? If it is legally binding, does that mean that Congress cannot extend copyright or patent protection in a particular instance if that extension does not "promote the Progress of Science and useful Arts," but serves some other end? Should "limited Times" be read literally or should the Preamble's purpose influence the understanding of what constitutes a "limited Time[]"? Is there any outer limit to what constitutes a "limited Time[]"? If Congress's power to provide copyright or patent protection is only proper if the exercise of that power advances certain ends, how tight must the fit between means and ends be? More fundamentally, how closely should courts scrutinize congressional exercises of power under the Copyright Clause?

A group of scholars that we call the IP Restrictors has answered these questions in a fashion that would sharply limit congressional authority under the Copyright Clause. And the Eldred litigation represented an attempt to convince the Supreme Court of the validity of their answers. At

18. U.S. CONST. art. I, $\S 8$. The quoted constitutional provision empowers Congress to create both patents and copyrights. When we refer in this Essay to the Copyright Clause, we, like the Court in Eldred, refer to a part of that provision: "Congress shall have Power . . . [t]o promote the Progress of Science ... by securing [to Authors] for limited Times ... the exclusive Right to their ... Writings." Eldred, 123 S. Ct. at 774 (quoting the text of the "Copyright and Patent Clause," which the Court subsequently refers to as the "Copyright Clause") (alterations in original). 
the most immediate level, the plaintiffs in Eldred were challenging the constitutionality of the CTEA. Yet, in raising the claim that the Copyright Clause restricts the manner by which Congress may secure rights in information, the Eldred litigants fit within a larger and more important jurisprudential movement.

Understanding the jurisprudential agenda behind the petitioners' arguments in Eldred requires consideration of the views of the IP Restrictors. Many of today's leading IP scholars share at least some of the concerns of this movement, and their views have attained the status of a new orthodoxy in the academy. In this Part of our Essay, we analyze the views of these scholars and trace the constitutional claims that grow out of their views. The IP Restrictors generally share common beliefs concerning a range of issues. These shared beliefs include the need to preserve a rich public domain; an economic-utilitarian approach to intellectual property; a textualist argument regarding the words of the Copyright Clause; and originalist arguments suggesting that the Copyright Clause enshrines a quid pro quo theory (i.e., an author must give the public something new in exchange for copyright protection), and that the Framers anticipated public choice scholarship and opposed copyright term extension as rent-seeking.

\section{A. The Normative Vision}

We begin with the normative part of the agenda. The IP Restrictors fear that too much legislative protection of copyright and copyright-like interests has already fenced in a rich public domain. As Benkler summarizes, "We are in the midst of an enclosure movement in our information environment." ${ }^{\text {19 }}$ Benkler sees the legal system "making a series of decisions that will subject more of the ways in which each of us uses information to someone else's exclusive control. ${ }^{, 20}$ For Benkler and other IP Restrictors, the public domain and copyright are inversely correlated: If one grows, the other must shrink. Intellectual property must therefore be restricted if the public domain is to be large and robust. ${ }^{21}$

In the IP Restrictors' judgment, the public domain serves two important functions related to intellectual property. First, it promotes the public's

19. Yochai Benkler, Free as the Air to Common Use: First Amendment Constraints on Enclosure of the Public Domain, 74 N.Y.U. L. REV. 354, 354 (1999),

20. Id. at 354-55. In Benkler's imagery, public resources, once as free as the air we breathe, are being taken from us through the law's expansion of copyright and copyright-like interests. Id. at 354-60.

21. As we shall see later in this Essay, this view of the inverse correlation between the public domain and copyright is contestable. For example, William Landes and Richard Posner argue in a recent paper that "it is a mistake to treat the public domain as a fixed supply of works from which any enlargement of copyright protection subtracts." William M. Landes \& Richard A. Posner, Indefinitely Renewable Copyright, 70 U. CHI. L. REV. 471, 474 (2003). 
interests as consumers. Second, it facilitates innovation by the creators of intellectual property. In its first function, the public domain allows the public as consumers of intellectual property to enjoy works at a lower cost, which may even approach zero in our Information Age. Mark Lemley makes this point in his Eldred amicus brief, arguing that digital technology makes material in the public domain universally available. ${ }^{22}$ So long as the law resists copyright extension, a "universally accessible" library, and one that dwarfs the Library of Congress, "is within our grasp.","3

A strong public domain also assists artists who seek to create intellectual property. ${ }^{24}$ After all, it is the public domain that furnishes the raw material for the creation of new works. William Landes and Richard Posner made this point decades before the current copyright-extension debate began. In their analysis, a copyright protection that starves the public domain also limits the production of creative works by constraining authors' ability to draw on preexisting works. ${ }^{25}$

The IP Restrictors also bolster their view regarding the worth of the public domain by pointing to a deep irony present in the current landscape for intellectual property. The irony begins with the Disney Corporation drawing great benefits from the public domain by making its own (copyrighted) versions of publicly available tales such as Sleeping Beauty, Snow White, Cinderella, and Pinocchio. Although this public domain source material traces its origins to Jacob and Wilhelm Grimm, two nineteenth-century German linguists, philologists, and collectors of folktales, Disney has been among the most aggressive advocates of expanded copyright protection. ${ }^{26}$ As Lessig observes, the CTEA ensures that "no one can do to Disney as Disney did to the Brothers Grimm.",27

22. Brief of Amicus Curiae The Internet Archive at 2, Eldred (No. 01-618).

23. Id. at 3 . The Brief notes, "Projects to digitize and give away millions of out-of-copyright books, movies, and music are now underway, funded by foundations, the government and indeed corporations." Id. at 2.

24. Sterk, supra note 4, at 1208.

25. William M. Landes \& Richard A. Posner, An Economic Analysis of Copyright Law, $18 \mathrm{~J}$. LEGAL STUD. 325, 342-43 (1989). As we will discuss in more detail later in this Essay, however, Landes and Posner propose more recently that "even with an unlimited right of renewal the public domain would remain a vast repository of intellectual 'property' (in a legal sense, nonproperty) available for use without charge and also usable as free inputs into the creation of new intellectual property." Landes \& Posner, supra note 21, at 474.

26. As we later argue, however, we feel that this particular problem is best handled with recourse to such statutory exceptions to copyright as the "fair use" and "parody" exceptions. See infra text accompanying notes 401-402.

27. See Steven Levy, Lawrence Lessig's Supreme Showdown, WIRED MAG., Oct. 2002, at http://www.wired.com/wired/archive/10.10/lessig.html.

For a different reading of copyright by a different kind of IP Restrictor, see Jed Rubenfeld, The Freedom of Imagination: Copyright's Constitutionality, 112 YALE L.J. 1 (2002). Rubenfeld views copyright as a constitutional matter constrained by a "Freedom of Imagination" located in the First Amendment. While we will not be discussing the many important issues raised by the interface of copyright and First Amendment issues in this Essay, we do wish to make two observations about Rubenfeld's concept of Freedom of Imagination, which would prevent anyone 
The IP Restrictors contrast their view of the twin benefits of the public domain with an economic-utilitarian view of the fruits of intellectual property. For them, intellectual property's purpose is to encourage both the creation of works of authorship and their dissemination. As Raymond $\mathrm{Ku}$ explains, law "makes it possible to have a private market for works of authorship by artificially rendering those works scarce and exclusive." 28 Copyright should provide just enough incentive for production and dissemination, but no more. ${ }^{29}$ Stewart Sterk has proposed that "copyright [be] justifiable only to the extent that copyright protection is necessary to induce additional creative activity."30 For IP Restrictors, too much copyright protection will not only hurt the public domain, but will also discourage investment elsewhere. ${ }^{31}$

\section{B. The Textualist Vision}

The IP Restrictors not only make normative arguments about copyright's purpose, but also support these ideas with textualist evidence. For the IP Restrictors, the constitutional text provides clear indications of the Framers' desire to limit copyright protections. For one thing, the Clause begins with the words, "To promote the Progress of Science and useful Arts." 32 As Paul Heald and Suzanna Sherry state, this grant of power to Congress "begins with a prescription of proper legislative purpose." Copyright's purpose is to promote "Science," which at the time of the

from being legally punished "for thinking an unauthorized thought or for expressing an unauthorized idea." Id. at 60. First, it has a large hole at its center because it ignores obscenity law, which does exactly what Rubenfeld would forbid copyright to do: It punishes certain kinds of thought. See id. at 37-39 (emphasizing the "communicative" aspects of imagination, by which Rubenfeld means both "what artists do and what audiences do," and stating that his Freedom of Imagination extends to both high and low culture). Second, Rubenfeld proves to have scant interest in the copyright/First Amendment interface, except for a comment that the core prohibition of copyright is "piracy, meaning unauthorized duplication (and sale) of another's work." Id. at 48.

28. Ku, supra note 4 , at 279.

29. Indeed, Justice Stephen Breyer, while a Harvard Law School professor, made the argument that copyright extensions are problematic from an economic-utilitarian perspective. Stephen Breyer, The Uneasy Case for Copyright: A Study of Copyright in Books, Photocopies, and Computer Programs, 84 HARV. L. REV. 281 (1970). Yet, the Constitution, of course, explicitly establishes copyright law as within the power of Congress.

30. Sterk, supra note 4, at 1213. For a critique of this view, see Neil Weinstock Netanel, Copyright and a Democratic Civil Society, 106 YALE L.J. 283, 338-40 (1996).

31. In Ku's view, excessive copyright will "discourage investments in every other sector of the economy." Ku, supra note 4, at 321 . Ku imagines that too much copyright protection might create "asymmetrical incentives" for people to become, for example, musicians. Id. Instead, an ideal level of copyright would "place the financial incentives to become a musician on a level playing field with other careers." Id. Indeed, Ku would go so far as to abolish copyright for digital music. Id. at 300-05.

32. U.S. CONST. art. I, \& 8, cl. 8.

33. Heald \& Sherry, supra note 4 , at 1153. 
Constitution's promulgation meant "knowledge" or "learning.",34 A copyright statute that did not advance knowledge or learning would violate the Preamble. As Heald and Sherry express it, " $[A] n$ author or inventor may not be given something for nothing; the author or the inventor must give the public something it did not have before to earn a grant of exclusive rights from Congress. ${ }^{35}$ From the IP Restrictors' perspective, this quid pro quo theory is not merely normative; it is a requirement embedded in the Copyright Clause. In other words, the Constitution itself requires the IP Restrictors' policy vision.

Moreover, this language, in the view of Heald and Sherry, "take[s] a clear side in the debate over whether natural law or classical economics provides the best justification for protecting intellectual property." ${ }^{36}$ The Preamble demonstrates that the granting of rights under the Clause "is driven by the goal of enhancing public welfare." 37 To comport with the Preamble, a copyright must further the public welfare.

Further important textual evidence is provided by the language that states that Congress is to act "by securing [protection] for limited Times to Authors and Inventors." ${ }^{38}$ Limited times means that the protection period for intellectual property could not be perpetual. For Heald and Sherry, this text also provides "structural evidence of the framers' view of intellectual property as ... designed for the public benefit." 39 After a "limited time" was over, the Framers wished to ensure that "valuable inventions and writings would inevitably belong to the public. ${ }^{40}$ In brief, the IP Restrictors argue the Copyright Clause only permits Congress to grant (1) "limited" copyrights that will also (2) promote the "Progress of Science."

\section{The Originalist Vision}

Beyond the textual reading, the IP Restrictors also provide originalist arguments, which bring us back to the IP Restrictors' quid pro quo theory. In making these arguments, the IP Restrictors read the Framers' views at a high level of abstraction. This tactic is necessary because of the thinness of the existing historical record supporting their view. ${ }^{41}$ Consider in this context the approaches of Benkler as well as Heald and Sherry. Benkler makes a highly unconventional originalist linguistic argument, which turns

34. Brief for Petitioners at 15 n.4, Eldred v. Ashcroft, 123 S. Ct. 769 (2003) (No. 01-618) [hereinafter Petitioners' Brief].

35. Heald \& Sherry, supra note 4 , at 1162.

36. Id. at 1154 .

37. Id.

38. U.S. CONST. art. I, $\S 8, \mathrm{cl} .8$.

39. Heald \& Sherry, supra note 4 , at 1154 .

40. Id. at 1155 .

41. For our own survey of this historical record, see infra Part IV. 
on the Framers' alleged understanding of a single word: "Progress.,"42 Heald and Sherry's approach looks more like classic originalism, but in the absence of any strong evidence, such as statements at the Constitutional Convention or in the ratifying debates, they, like Benkler, are also forced to operate at a high level of abstraction. ${ }^{43}$

Benkler's unconventional originalism takes the form of a miniintellectual history of the concept of "Progress," a word which is found, of course, in the Copyright Clause's Preamble. ${ }^{44}$ The word "Progress" leads Benkler to conclude that the Founders did not see "private rights in information and knowledge" as the kind of "property rights to be cherished and protected. ${ }^{, 45}$ But why did the Framers dislike these private rights?

In Benkler's view, the Framers were worried about private monopolies in information because such exclusive grants harmed the common enterprise that is Progress. ${ }^{46}$ Private rights in information and knowledge do not further a communal purpose; rather, they generally supply a benefit only to the person who receives the monopoly. ${ }^{47}$ According to Benkler, the Framers viewed "monopolies" as "exclusive rights to segments of the great process of Progress." ${ }^{48}$ Such exclusive rights were "to be feared and curtailed. $" 49$

Heald and Sherry also work at a high level of abstraction, claiming that the English experience with crown monopolies informed the Framers' notion of the Copyright Clause. ${ }^{50}$ Thus, Heald and Sherry point to a mood of "general skepticism about protecting intellectual property" at the time of the framing of the Constitution. ${ }^{51}$ In addition, they argue, again with relatively scant evidence, that "there is little doubt" that the Framers "were aware of ... the perceived dangers of monopolies" as demonstrated by the abuse of the copyright and patent systems in England. ${ }^{52}$ Heald and Sherry see the Framers as drafting the Copyright Clause in response to the misuse of the copyright and patent systems in England and in recognition of the

42. Benkler, supra note 4, at 569-74.

43. For example, Heald and Sherry impute to the Founders significant concern with historical events in England and the English Crown's past practice of using copyright and patent to crush dissent and reward royal courtiers. Heald \& Sherry, supra note 4, at 1142-53. Yet, as we argue later, no such evidence exists to demonstrate that the Founders had the English experience primarily in mind when drafting the Copyright Clause or ratifying the Constitution. See infra notes $270-271$ and accompanying text.

44. Benkler, supra note 4, at 569-74.

45. $I d$, at 570 .

46. $I d$ at 571 .

47. Id. at $571-72$.

48. Id at 571 .

49. Id.

50. Heald \& Sherry, supra note 4 , at 1143-46.

51. Id. at 1150.

52. Id. at 1144 . 
English reaction against this behavior. ${ }^{53}$ In their view, the Framers' skepticism regarding legislation that created "suspect grants," by which they mean monopoly-like costs, led the Framers to embed a quid pro quo requirement in the Copyright Clause. ${ }^{54}$ As Heald and Sherry state, "legislation creating a suspect grant," i.e., a monopoly, "must be in the form of a bargain: author or inventor creates, then author or inventor gets reward.",55

\section{Public Choice Theory}

The IP Restrictors also view the Framers as having embedded a judgment in the Copyright Clause that anticipates public choice scholarship in its hostility to rent-seeking. Public choice theory, also known as the economic theory of legislation, engages in a critique of the process by which legal rules are enacted. ${ }^{56}$ According to this theory, the legislative process suffers from organizations' tendency to engage in rent-seeking. ${ }^{57}$ Potential transfer recipients seek to capture the legislative process in order to extract "rent." 58

For the IP Restrictors, copyright extension is a classic example of rentseeking by powerful special-interest groups, namely, the dreaded copyright dinosaurs, copyright colonists, and Soviets (in the respective language of Pamela Samuelson, Jessica Litman, and Lessig). ${ }^{59}$ Rather than adapt to new technology, copyright holders, such as Disney, would rather extract rent from the legislative process in the form of copyright extension. As an example of this perspective, Litman argues, "Copyright legislation written by multiparty negotiations is... overwhelmingly likely to appropriate value for the benefit of major stakeholders at the expense of the public at

53. Id at $1144-45$.

54. Id at 1160-63.

55. Id. at 1162-63.

56. For a concise introduction to public choice law, see DANIEL A. FARBER \& PHILIP P. FRICKEY, LAW AND PUBLIC CHOICE (1991).

57. See Jonathan R. Macey, Public Choice and the Law, in 3 THE NEW Palgrave DICTIONARY OF ECONOMICS AND THE LAW 171 (Peter Newman ed., 1998) [hereinafter PALGRAVE DICTIONARY].

58. Robert D. Tollison, Rent Seeking, in 3 PALGRAVE DictionarY, supra note 57, at 315 , 316-17.

59. Samuelson described an attempt to "provide massive subsidies to the dinosaurs of ... today's largely print-based copyright industry, which are terrified of the digital domain and generally don't have the faintest idea about how to market the content in their portfolios on the Net."' LITMAN, supra note 4, at 89 (quoting Pamela Samuelson, The Copyright Grab, WIRED MAG., Jan. 1996, at http://www.wired.com/wired/archive/4.01/white.paper_pr.html). Jessica Litman more than matched Samuelson's criticism; Litman sees copyright lawyers as out to "colonize" cyberspace. Id. And, depending on one's perspective, Lessig may have trumped the terms "dinosaur" and "colonists" in his description of the copyright industry as the new "Soviets." LESSIG, supra note 4, at 145-46; see also infra text accompanying notes 99-100. 
large." ${ }^{60}$ For Litman, copyright stakeholders extract legislation from the political system that takes the form of "rent-seeking at the expense of new upstart industries and the public at large." ${ }^{.61}$ In short, copyright stakeholders will "produce a scheme designed to protect themselves against the rest of us. $" 62$

It is not just that copyright legislation, such as the CTEA, is rentseeking, but also that the Framers intended the Copyright Clause to stop precisely such behavior. Consider Heald and Sherry's view on this issue; these two scholars trace a line (1) from Elizabethan England (2) to the Framers and (3) onward to the congressional enactment of the CTEA in $1998 .^{63}$ Heald and Sherry argue that "the term extension [of the CTEA] looks very much like the same sort of abuse condemned by Parliament and the English courts in the two centuries before the Constitutional Convention." ${ }^{64}$ As Heald and Sherry summarize, the "CTEA has precisely the same effects as the Elizabethan grant of a monopoly in ale or printing." 65 Instead of an Elizabethan courtier, such as "a Stationers" Company member who received a printing patent," however, we now have different kinds of legislative favorites. ${ }^{66}$ Heald and Sherry identify these groups as the modern, functional equivalent of the English courtier: "ASCAP, Disney, the Association of American Publishers, the Motion Picture Association of America, and the Music Publishers Association, among others. ${ }^{167}$ Thus, like the Elizabethan grant, the congressional action in enacting the CTEA guarantees an income stream to a legislative favorite without a benefit to the public. And it is precisely this behavior that the Framers are said to have opposed in enacting the Copyright Clause and its quid pro quo requirement. ${ }^{68}$

In conclusion, it is no accident that so many leading scholars of intellectual property law are among the IP Restrictors. Goods held in common-public goods - are as much a part of the wealth of a society as private goods. Yet, the market may prove unable to provide and protect critical public goods. Outside of the field of intellectual property, scholars are considering how to maintain public goods in the environment, public health, and financial markets. ${ }^{69}$ Within the area of intellectual property, the

60. LITMAN, supra note 4, at 144.

61. Id. at 145 .

62. Id. at 62 .

63. Heald \& Sherry, supra note 4 , at $1169-71$.

64. Id. at 1169 .

65. Id. at 1170 .

66. Id.

67. Id.

68. Id. at $1169-70$.

69. For a sampling of representative views, see DAvid Bollier, SILENT THEFT: THE Private Plunder OF OUR COMMON WEALTH (2002); and Global Public GoOds: INTERNATIONAL COOPERATION NN THE 21ST CENTURY (Inge Kaul et al. eds., 1999). 
key public good is, of course, the public domain. And the public domain, as these scholars have observed, may be under siege due to the steady expansion of copyright law. As Lessig and others have noted, Disney and others are seeking to legislate themselves out of the process through which creators draw on common cultural icons. The IP Restrictors also draw on an economic-utilitarian view of copyright, which is predominant in the field of intellectual property law in the United States. Thus, there are appealing aspects of both the IP Restrictors' normative agenda and the intellectual platform from which that agenda is being advocated.

\section{ELDRED V. ASHCROFT}

Thus far, we have traced the IP Restrictors' arguments. We now wish to analyze the petitioners' claims before the U.S. Supreme Court in Eldred $v$. Ashcroft, relate their litigation to the IP Restrictors' theories, and discuss the Eldred Court's opinion. We conclude this Part by arguing that in certain critical ways the Eldred decision remains inadequately theorized. Moreover, despite the Court's seemingly solid 7-2 vote upholding the CTEA, Eldred may prove unstable for other reasons, which we will explore below.

\section{A. Eldred's Claims}

In Eldred, petitioner Eric Eldred, a publisher of HTML books, ${ }^{70}$ and other individuals and companies who use public domain materials argued that the CTEA unconstitutionally blocked a new crop of material from entering the public domain. ${ }^{71}$ The Eldred petitioners' main doctrinal argument had three distinct strands. It began with the proposal that (1) the Copyright Clause had to be read as an "enumerated power" subject to limits. ${ }^{72}$ The petitioners then proposed that the necessary limits on the Clause were supplied by (2) a reading of the "limited Times" provision of the IP Clause with (3) the "Progress of Science" Preamble. ${ }^{73}$

70. His website, called Eldritch Press, is located at http://209.11.144.65/eldritchpress/. For a further discussion, see LESSIG, supra note 4, at 122-23. Other plaintiffs in the case included a nonprofit film-preservation group; publishers of historical works, including maps and material relating to golf; and Dover Publications, a commercial publisher of "high-quality paperback books," which "had planned to republish a number of works from the 1920's and 1930's." Petitioners' Brief, supra note 34, at 3-6.

71. Petitioners' Brief, supra note 34 , at 3 . The CTEA also applies prospectively to new works, but the petitioners did not challenge this lengthening of the copyright period as inconsistent with the Clause. Instead, they challenged only the Act's retroactive application to works already created.

72. Id. at 11-14.

73. Id. at 14-28. The petitioners also claimed that, by protecting works already created, the statute was at odds with the requirement that the Copyright Clause protect only original works. $I d$. 
Thus, the petitioners' initial proposition was that the Copyright Clause was another enumerated power of the Constitution subject to limits that were to be judicially determined. The petitioners cited recent cases limiting the exercise of congressional powers such as United States $v$. Morrison, ${ }^{74}$ Kimel v. Florida Board of Regents, ${ }^{75}$ City of Boerne v. Flores,${ }^{76}$ and United States $v$. Lopez. ${ }^{77}$ These cases establish the critical principle that courts should look closely at whether congressional statutes fall within the limits of enumerated powers. ${ }^{78}$

What were the limits then on Congress's power under the Copyright Clause? For Eldred, a retroactive extension of copyright protection violated the "limited Times" term of the Copyright Clause (step one) because a "limited time" for copyright protection necessarily had to promote the "Progress of Science" (step two). On behalf of Eldred, Lessig did not claim that the Preamble was legally enforceable-only that it informed the reading of the rest of the text. ${ }^{79}$ In making this claim, Eldred adopted the IP Restrictors' core arguments regarding the public domain, the economicutilitarian view of intellectual property, the constitutional text, and the Framers' original intent. ${ }^{80}$ This Section will consider the links between Eldred's arguments and those of the IP Restrictors, concluding with an analysis of Eldred's claims regarding the proper standards of judicial review.

at 32-33. While the text of the Clause does not explicitly require originality as a precondition for protection, the Supreme Court in Feist Publications, Inc. v. Rural Telephone Service Co. concluded that "[t]he sine qua non of copyright is originality." 499 U.S. 340,345 (1991).

74. 529 U.S. $598(2000)$.

75. 528 U.S. $62(2000)$.

76. 521 U.S. 507 (1997).

77. 514 U.S. $549(1995)$.

78. At the appellate level, Judge Sentelle, writing in dissent, accepted this argument and stated, "It would seem to me apparent that this concept of 'outer limits' to enumerated powers applies not only to the Commerce Clause but to all the enumerated powers, including the Copyright Clause, which we consider today." Eldred v. Reno, 239 F.3d 372, 381 (D.C. Cir. 2001) (Sentelle, J., dissenting), aff'd sub nom. Eldred v. Ashcroft, 123 S. Ct. 769 (2003).

79. Petitioners' Brief, supra note 34, at 15-17.

80. The Court rejected another argument offered by Eldred, which concerned the Copyright Clause's protection of only "original works," noting that its Feist decision did not concern the duration of copyright, but rather the "core question of copyrightability, i.e., the "creative spark" a work must have to be eligible for copyright protection at all." Eldred, $123 \mathrm{~S}$. Ct. at 784 . The Eldred Court stated that Feist "did not construe the 'limited Times' for which a work may be protected, and the originality requirement has no bearing on that prescription." Id. This judgment is similar to that of the D.C. Circuit in rejecting Eldred's reading of Feist. The D.C. Circuit did, however, go into somewhat more detail than the Supreme Court in distinguishing Feist. For the D.C. Circuit, Feist was simply about "whether any work is copyrightable"-it was a case concerning whether copyright protection could be extended to facts in works (i.e., telephone books, and, more specifically, the white pages) that were mere collections of fact. Eldred, 239 F.3d at 377. Thus, the requirement of originality was not at stake in Eldred in the Feist sense because "the relevant works," i.e., the works the copyright period of which the CTEA extended, "are already copyrighted." Id. A finding of originality had already been made. 
On a normative level, the Eldred petitioners clearly supported a flourishing public domain and criticized the destructive impact of copyright extension on this goal. Eldred's co-plaintiffs in this case included Dover Books, publishers of hard copy versions of public domain material, and assorted music and film publishers of similar content. As the D.C. Circuit explained, "The plaintiffs benefit from using works in the public domain and, but for the CTEA, they would be able to exploit additional works the copyrights to which would have expired in the near future."

In their brief to the Supreme Court, the petitioners argued that permitting Congress to extend copyright terms would mean that "no author or artist can rely upon work passing into the public domain." blocks the "director who wants to adapt a play in a manner inconsistent with the original author's wish" because she will "never know when the author's rights will end." ${ }^{83}$ It also handicaps efforts (such as Eldred's) to create online libraries of public domain works "with a technological capacity far exceeding that of the ordinary library." ${ }^{\prime 4}$ The statute harms the choir director in Athens, Georgia, who wants to perform works by Ralph Vaughan Williams and Edward Elgar once these works have entered the public domain. ${ }^{85}$ The CTEA harms these petitioners by blocking their access to content that they had been waiting to use. Had these works entered the public domain, Eldred could add more content to his website, the hypothetical director could see a play performed in a fashion inconsistent with the author's wishes, and the choir director could afford to perform the works by Williams and Elgar.

Invoking the IP Restrictors' economic-utilitarian arguments, Eldred argued that, as a categorical matter, retrospective extensions could not "promote the Progress of Science." For Eldred, "Retroactive extensions cannot 'promote' the past.... No matter what we offer Hawthorne or Hemingway or Gershwin, they will not produce anything more." ${ }^{, 86}$ In their case and for all retroactive extensions, it makes no economic sense to create an incentive "for work that has already been produced." 87

As Eldred's reference to these deceased artists makes clear, the economic-utilitarian argument is also tied to the quid pro quo theory. The reference to the late creators serves as an extreme example of why retroactive extensions lack any quid pro quo-Hawthorne, Hemingway, or Gershwin will produce no more art in exchange for the copyright extension.

81. Eldred, 239 F.3d at 375.

82. Petitioners' Brief, supra note 34, at 18.

83. Id.

84. Id. at 5 .

85. Id. at $4-5$

86. Id.

87. Id. 
But the same point also applies to living artists as well; once a work is created, giving the creator more compensation is simply a windfall.

What about textualism? In his brief for the Eldred petitioners, Lessig first noted that the word "limited" had the same plain meaning at the time of the Founding as today. ${ }^{88}$ Citing Webster's Dictionary, he wrote, "A term is limited if it is 'appointed, fixed,' 'narrow,' or 'circumscribed." ${ }^{\prime 89}$ Further evidence is also provided by Samuel Johnson's famous eighteenth-century dictionary, which defines "to limit" as "to confine within certain bounds; to restrain; to circumscribe; not to leave at large." $" 90$

A limited time must not only be "fixed," to use Webster's terminology, but it must also have a determinate end. It cannot be subject to endless openings and closings. As Lessig stated in oral argument in Eldred, "limited" in the IP Clause is to be understood in the same way as a "limited [edition] print." ${ }^{.91}$ When one speaks of a limited edition Picasso print, the general meaning is that further reproductions from a master plate are not to be allowed after the initial run. In a similar fashion, a copyright that the Constitution grants for "limited Times" cannot be extended.

In his Eldred brief, Lessig also adopted the IP Restrictors' point about the constitutional status of the quid pro quo theory. ${ }^{92}$ For Lessig, "[T]he text and structure of the rights part of the Copyright Clause ... imbeds a quid pro quo." ${ }^{.93}$ Congress may trade a grant of a right for a limited time only in exchange for a writing by an author. But Congress cannot create windfalls for authors: "It may not hand out a monopoly over speech in exchange for nothing-quid pro nihilo." 94 In Lessig's judgment, the CTEA is simply "a boon to the heirs of copyright holders." 95 To borrow a figure of speech from a famous song by Dire Straits, we can say that Lessig and the IP Restrictors see this statute as providing "money for nothing."

Eldred also explicitly embraced the IP Restrictors" quid pro quo theory. As Lessig argued on Eldred's behalf, the Constitution gave Congress the power to "make a trade": In exchange for protection for "limited Times," copyrighted material would eventually pass into the public domain. ${ }^{97}$ Only linking intellectual property to a public commons for this material would assure the constitutional mandate of "progress." In contrast, a monopoly

88. Id. at 17 .

89. Id (quoting WEBSTER'S NEW INTERNATIONAL DICTIONARY 1434 ( $2 \mathrm{~d}$ ed. 1950)).

90. Id. (quoting 2 SAMUEL JOHNSON, A DICTIONARY OF THE ENGLISH LANGUAGE (London, W. Strahan 1755)).

91. Transcript of Oral Argument at 24, Eldred v. Ashcroft, 123 S. Ct. 769 (2003) (No.

01-618), at http://supremecourtus.gov/oral_arguments/argument_transcripts/01-618.pdf.

92. Petitioners' Brief, supra note 34, at $15-17$.

93. Id at 23.

94. Id.

95. Id.

96. Dire Straits, Money for Nothing, on BROTHERS IN ARMS (Warner Bros. 1985).

97. Petitioners' Brief, supra note 34, at 23. 
over speech could not be granted in exchange for nothing. Rather than a quid pro quo, however, "a boon to the heirs of copyright holders" through retroactive copyright extension was simply a windfall, which may be granted by Congress "through tax benefits, or outright gifts," but not through retroactive extension of copyright. ${ }^{98}$

After making the IP Restrictors' arguments about the Framers' distrust of monopolies, Lessig quickly reached the public choice strain within these scholars' jurisprudence. Lessig wrote, "Today, the conduct that the Framers sought to prevent would be called 'rent-seeking." Lessig draws a line that connects the past and present. His line goes from the Framers of this country to the three chief founders of public choice theory. Quoting James Buchanan, Robert Tollson, and Gordon Tullock in a description of the original understanding, Lessig wrote, "The Framers ... recognized that governmental grants of exclusive rights for already existing creations served no social end, but merely induced private parties to dissipate 'effort, time and other productive resources' in currying lawmakers' favor." 100

In the end, the question hovering in the background of Eldred was how deferential courts should be in evaluating legislation under the Copyright Clause. Before the D.C. Circuit, Eldred asked for and failed to obtain heightened judicial review of the CTEA. The appellate court, unlike Judge Sentelle in dissent, emphasized the need for a relaxed standard of review of the "limited Times' for which the Congress has set the duration of copyrights." 101 It stated, "that decision is subject to judicial review only for rationality" and found that the CTEA passed muster under that standard. ${ }^{102}$

While the heightened review issue was central to Eldred's argument before the court of appeals, it was, before the Supreme Court, a fallback argument. ${ }^{103}$ Eldred's principal argument concerned the per se invalidity of any retrospective extension of copyright protection. Thus, the petitioners were urging the adoption of a bright-line rule. Retrospective extension was said to violate the "limited Times" requirement of the Copyright Clause because Congress could use a series of such extensions to make intellectual

98. Id.

99. Id. at 25 .

100. Id. at 25-26 (quoting James M. Buchanan, Rent Seeking and Profit Seeking, in TOWARD A THEORY OF RENT-SEEKING SOCIETY 3, 8 (James M. Buchanan et al. eds., 1980)).

101. Eldred v. Reno, 239 F.3d 372, 380 (D.C. Cir. 2001), aff'd sub nom. Eldred v. Ashcroft, 123 S. Ct. 769 (2003).

102. $I d$.

103. Eldred argued to the Supreme Court that the CTEA failed under such "heightened review" because the chief justification for retrospective extension-creating an incentive for copyright holders to restore decaying film - was insufficient to justify the broad extension provided by the statute. Petitioners' Brief, supra note 34, at 31 . Indeed, the petitioners' brief called the government's claim "simply astounding" and stated, "Just to encourage the preservation of film, a full generation of creative work is denied to another generation of creators." Id. at 32 . 
property protection permanent, ${ }^{104}$ because retrospective extension did not "promote the progress of science," 105 and because a quid pro quo requirement is implicit in the Copyright Clause. ${ }^{106}$ Retrospective extension was also said to violate the Copyright Clause's originality requirement since a work that has already been created is no longer "original." 107

In a sense, this set of arguments no longer embodied classic heightened review. In other words, the petitioners' challenge (unlike the first one before the court of appeals) did not ask the Court to review the legislation for a tight means-ends fit. At the same time, it still represented a rejection of deference to Congress. In the second set of arguments, the petitioners called for a bright-line test rather than a balancing test in the Supreme Court's close scrutiny of the relationship of means and ends.

The petitioners claimed that Congress could not be trusted to honor the "limited Times" proviso-that it would try to end-run that limitation through an endless series of extensions. Put concisely, the danger was that Congress would try to achieve a perpetual copyright term "“on the installment plan." "108 Eldred asked the Supreme Court to respond to Congress's untrustworthiness by fashioning a test that would deny them the opportunity to subvert the constitutional mandate. The petitioners also claimed that the Copyright Clause must be understood as embodying a series of judicially enforceable limits on congressional action that are far from apparent from the constitutional text-that intellectual property protections are illegitimate when a particular grant of protection does not promote the progress of science, that there must be a quid pro quo in return for the grant of rights, and that the concept of originality must be understood in a very limited way.

\section{B. The Supreme Court's Eldred Decision}

In a majority opinion written by Justice Ginsburg, the Supreme Court, by a 7-2 vote, rejected the petitioners' call for a per se rule against copyright extension as well as their fallback call for heightened review. The Court found that " $[\mathrm{t}] \mathrm{ext}$, history, and precedent" confirm that the Copyright Clause empowers Congress to enact the CTEA. ${ }^{109}$ In this Section, we discuss the Eldred opinion and the two dissents. In the next Section, we set out reasons why we think this opinion may prove less than solid as precedent.

104. Id. at $17-19$.

105. Id. at $19-22$.

106. Id. at 23.

107. Id. at $32-33$.

108. Id. at 18 (quoting Senate testimony of Professor Jaszi).

109. Eldred v. Ashcroft, 123 S. Ct. 769, 778 (2003). 
We have seen that Eldred adopted the IP Restrictors' core claims. How did the Supreme Court respond to these arguments? The majority opinion did not discuss the public domain, but repeatedly stressed Congress's role in deciding whether copyright legislation will further the ends of the Copyright Clause. Thus, in Justice Ginsburg's view, "The CTEA reflects judgments of a kind Congress typically makes, judgments that we cannot dismiss as outside the Legislature's domain.... [I]t is generally for Congress, not the Courts, to decide how best to pursue the Copyright Clause's objectives." 110

It was the dissenting Justices who addressed-and accepted-the petitioners' claims about the importance of the public domain and the detrimental effect of a copyright term extension. Justice Stevens asserted that "the overriding purpose of the constitutional provisions" is "ultimate public access" to material, that is, that copyright material enter the public domain. ${ }^{11}$ In his judgment, "Ex post facto extensions of existing copyrights, unsupported by any consideration of the public interest, frustrate the central purpose of the Clause." 112 Justice Breyer similarly saw the Copyright Clause as constructed so as to favor the public domain. In his words, "The Clause assumes an initial grant of monopoly, designed primarily to encourage creation, followed by termination of the monopoly grant in order to promote dissemination of already-created works."113

Although the majority did not address the issue of the public domain, it did adopt the economic-utilitarian view. For example, the majority stressed that copyright law "celebrates the profit motive" for authors. ${ }^{114}$ But the Court also found, as we have already noted, that it was "generally for Congress, not the courts, to decide how best to pursue the Copyright Clause's objectives." 115 And the Eldred Court rejected the idea that the only way to promote "the Progress of Science" was to provide incentives to create new works. ${ }^{116}$

An initial legitimate basis for the CTEA, for example, was the harmonization of U.S. law with European copyright. Harmonization would allow American authors to take advantage of a reciprocity provision found in a European Union (EU) copyright directive; non-EU countries that

110. Id. at 781 .

111. Id. at 800 (Stevens, J., dissenting).

112. Id.

113. Id. at 810 . It is the "disappearance of the monopoly grant ... that will, on balance, promote the dissemination of works already in existence." Id. Even if the grant of a copyright monopoly occasionally did help publishers resurrect works of long-lost artistic geniuses, the Copyright Clause denied Congress "power to base its actions primarily upon that empirical possibility." Id.

114. Id. at 785 n.18 (quoting Am. Geophysical Union v. Texaco Inc., 802 F. Supp. 1, 27 (S.D.N.Y. 1992), aff'd, 60 F.3d 913 (2d Cir. 1994)).

115. Id. at 785 .

116. Id. at 773 . 
matched Europe's "life of the author plus 70 years" term would be entitled to the same copyright protection as their European counterparts. Harmonization might also cause economic incentives "for American and other authors to create and disseminate their work in the United States."117

Beyond the international justifications, the majority opinion also justified the CTEA on economic-utilitarian grounds. The Eldred Court spoke of congressional enactment of the statute "in light of demographic, economic, and technological changes," such as increases in human longevity, and a belief that "longer terms would encourage copyright holders to invest in the restoration and public distribution of their works.",118 Among the evidence that Congress considered in enacting the CTEA was testimony from prominent musicians, such as Quincy Jones, Bob Dylan, Don Henley, and Carlos Santana, "that the copyright system's assurance of fair compensation for themselves and their heirs was an incentive to create." ${ }^{19}$ Longer copyright protection would thus usefully further various economic-utilitarian goals.

The Eldred Court also rejected the petitioners' textual argument about copyright legislation requiring the setting of a "limited Time[]." The Court claimed that the petitioners read into the Copyright Clause's text "the command that a time prescription, once set, becomes forever 'fixed' or 'inalterable." ${ }^{20}$ The Court stated that at the time of the Framing, as today, the contested word simply meant "confine[d] within certain bounds." 121 As a consequence, "a time span appropriately 'limited' as applied to future copyrights does not automatically cease to be 'limited' when applied to existing copyrights." 122

On a more complex level, however, the petitioners" "limited Times" argument read the Preamble (regarding the "Progress of Science") into the text of the Clause. ${ }^{123}$ Regarding the petitioners' "preambular argument," the Eldred Court found that it was generally for Congress, and not the courts, to decide how best to pursue the objectives of the Copyright Clause. ${ }^{124}$ The Court also gave significant weight not only to the policy reasons offered in support of the CTEA, but also to the longstanding congressional practice of copyright extensions. "On the issue of copyright duration, Congress, from

117. Id. at 782 .

118. Id.

119. Id. at 782 n. 15 .

120. $I d$.

121. Id. at 778 (quoting SAMUEL Johnson, A Dictionary OF THE ENGlish LANGUAGe (London, n.p. 7th ed. 1785) (defining "to limit")) (alteration in original).

122. Id. The Eldred Court also observed that a regime of perpetual copyrights was not before it. $I d$.

123. As Lessig writes, "The 'means' are enumerated in the rights part-"by securing for limited Times to Authors ... the exclusive Right to their... Writings."' Petitioners' Brief, supra note 34 , at 15 .

124. 123 S. Ct. at 785. 
the start, has routinely applied new definitions or adjustments of the copyright term to both future works and existing works not yet in the public domain." 125 The Court determined that this "unbroken practice since the founding generation ... overwhelms petitioners' argument that the CTEA's extension of existing copyrights fails per se to 'promote the Progress of Science." ${ }^{126}$

The Eldred Court looked not only at the numerous acts of Congress that applied duration extensions to both existing and future copyrights, ${ }^{127}$ but, noting that the "Clause empowering Congress to confer copyrights also authorizes patents," the Court also evaluated congressional practice concerning patents. ${ }^{128}$ It found that early congressional practice regarding patents was similar to that of copyrights, with numerous extensions granted. Indeed, "renewed or extended terms were upheld in the early days, for example, by Chief Justice Marshall and Justice Story sitting as circuit justices." 29 Early Supreme Court cases, including McClurg v. Kingsland, ${ }^{130}$ also upheld "expanded patent protection to an existing patent." 131

The dissenters did not address the IP Restrictors' textualist arguments explicitly. Justice Stevens did, however, discuss the "textual requirement that the author's exclusive rights be only 'for limited Times." 132 For Stevens, this requirement meant that "the express grant of a perpetual copyright would unquestionably violate" the Constitution's plain text. ${ }^{133}$ But he also noted that "a categorical rule prohibiting retroactive extensions would effectively preclude perpetual copyrights." ${ }^{134}$ Such a rule would have the benefit, moreover, of preventing Congress from "extend[ing] existing monopoly privileges ad infinitum under the majority's analysis." 135 Thus, Stevens accepted the petitioners' argument that the Copyright Clause prohibited perpetual copyright on the installment plan. ${ }^{136}$

125. Id.

126. Id. at $785-86$.

127. Id. at $778-79$.

128. Id. at 779 .

129. Id. The early cases decided by Marshall and Story were Evans v. Jordan, 8 F. Cas. 872 (C.C.D. Va. 1813) (No. 4564) (Marshall, J.), aff'd, 13 U.S. 199 (1815), and Blanchard v. Sprague, 3 F. Cas. 648 (C.C.D. Mass. 1839) (No. 1518) (Story, J.).

130. 42 U.S. (1 How.) 202 (1843).

131. Eldred, 123 S. Ct. at 780 n.9.

132. Id. at 800 (Stevens, J., dissenting).

133. Id.

134. Id.

135. Id. at $800-01$.

136. As for Breyer, he noted in passing that a "limited" time for copyright had to be "like 'a limited monarch." Id. at 804 (Breyer, J., dissenting) (quoting 2 SAMUEL JOHNSON, A DictionaRY OF THE ENGLiSH LANGUAGE (London, W. Strahan 4th rev. ed. 1773) (defining "to limit")). Turning to Samuel Johnson's celebrated eighteenth-century dictionary, he found this term to mean "'restrain[ed]" and 'circumscribe[d], 'not [left] at large." Id. (quoting 2 JoHNSON, supra) (alterations in original). A similar definition is also, of course, cited by the majority opinion in rejecting Eldred's claims. Id. at 778 (quoting JOHNSON, supra note 121). In judging 
As for Eldred's quid pro quo argument, the Eldred Court did not resolve whether the Copyright Clause mandated a quid pro quo, but simply found that a quid pro quo was present. Regarding the supposed need for a quid pro quo for any copyright extension, the Court observed that it could "demur to the petitioners' description of the Copyright Clause as a grant of legislative authority empowering Congress 'to secure a bargain-this for that," ${ }^{\prime 137}$ because such a bargain could be found in the CTEA. The Court stated:

Given the consistent placement of existing copyright holders in parity with future holders, the author of a work created in the last 170 years would reasonably comprehend, as the "this" offered her, a copyright not only for the time in place when protection is gained, but also for any renewal or extension legislated during that time. ${ }^{138}$

The legislative background to the CTEA was one in which Congress in extending copyrights always had included existing copyright holders; thus, the bargain of any creators included getting any future extension.

The majority also had to contend with the originalist argument that the Framers were generally opposed to copyright as a noxious monopoly. Justice Ginsburg did not contest these originalist claims; instead, she relied on Holmes's idea that "a page of history is worth a volume of logic."139 Ginsburg pointed to a history, reaching back to the First Congress, of "unbroken congressional practice of granting to authors of works with existing copyrights the benefit of term extensions so that all under copyright protection will be governed evenhandedly under the same regime." 140 In discussing the originalist evidence, Justice Ginsburg also pointed to three cases from the early part of the nineteenth century that upheld renewed or extended terms. ${ }^{141}$ These cases are particularly attractive due to their distinguished pedigree: "Chief Justice Marshall and Justice Story sitting as circuit justices" were part of the panel that decided these cases. ${ }^{142}$

Concerning the Framers' views, Justice Ginsburg tried to distinguish the U.S. history from the English experience that culminated in the Statute of Anne and a proposed amendment to this law. She first noted that in England, "concerns about monopolistic practices remained, and the 18th

that the Copyright Clause's requirements were not met, Breyer relied on his assessment of the originalist concerns as well as on an economic analysis-- not on a plain meaning analysis.

137. Id. at 786 (quoting Petitioners' Brief, supra note 34, at 16).

138. Id. (footnote omitted).

139. Id. at 778 (quoting N.Y. Trust Co. v. Eisner, 256 U.S. 345,349 (1921)).

140. Id.

141. Id. at 779 .

142. $I d$. 
century English Parliament was resistant to any enhancement of booksellers' and publishers' entrenched position." ${ }^{143}$ In contrast, Ginsburg observed that in this country, intense competition existed among publishers at the time of the Founding and that " $[t]$ he Framers guarded against the future accumulation of monopoly power in booksellers and publishers by authorizing Congress to vest copyrights only in "Authors."144 Thus, the majority's originalism was not only thin, but also positioned delicately between an attempt to distinguish the relevance of the English experience and an attempt to view the Framers' opposition to monopolies as centered in the Copyright Clause's concept of "Authors."

Justice Stevens vigorously rejected the majority's originalism, finding that the congressional practices upon which the majority relied so heavily contained actions that were not only unconstitutional by modern standards, but also "much more heterogeneous" than the majority acknowledged. ${ }^{145}$ Like the Eldred petitioners and IP Restrictors, Justice Stevens regarded at least some of the Framers as antimonopolist in their copyright views. He cited Madison as describing the Copyright/Patent Clause as a "fetter on the National Legislature,"146 and observed that the Copyright Act of 1790, the first copyright act, was patterned after the Statute of Anne of England. He also noted the successful English opposition to a 1735 amendment to this law that would have extended existing copyrights until 1756; Stevens asserted that the "authors of the federal statute that used the Statute of Anne as a model were familiar with this history."147

Justice Stevens further observed that Congress passed numerous bills between 1790 and 1875 that allowed applicants to apply for patent extensions. Of the seventy-five patents concerned, "at least 56 had already fallen into the public domain." ${ }^{148}$ This early practice was unconstitutional because Congress was awarding patent protection to inventions already in the public domain, as the Supreme Court explained in its 1966 decision, Graham v. John Deere Co. of Kansas City. ${ }^{149}$ Justice Stevens also rejected

143. Id. at 779 n.5.

144. Id.

145. Id. at 798 (Stevens, J., dissenting). The heterogeneous aspects of the historical record included early debate about the first Patent Act, which indicated an acknowledgment by members of Congress of "significant limitations on their constitutional authority under the Copyright/Patent Clause to extend protection to a class of intellectual properties." Id. at 794. Moreover, the first Copyright Act was best read as having created new rights-not extending old ones. $l d$. at 795 . As a result of the unconstitutionality of certain legislative action and the mixed congressional practice, "the history is not dispositive of the constitutionality of [the] Sonny Bono Act." Id. at 798.

146. Id. at 794 n.6 (quoting Letter from James Madison to Tench Coxe (Mar. 28, 1790), in 13 PAPERS OF JAMES MADISON 128, 128 (Charles F. Hobson \& Robert A. Rutland eds., 1981))

147. Id. at 796

148. Id. at 797 .

149. Id. at 798. The relevant language from the earlier case is at Graham v. Jahn Deere Co. of Kansas City. 383 U.S. 1, 5-6 (1966). The majority opinion sought to distinguish both Graham 
the early cases that Justice Ginsburg cited as proof of early practice because they involved material in the public domain. ${ }^{150}$ As a result, these early cases upholding copyright term extensions are inconsistent with modern case law. ${ }^{151}$

In Justice Breyer's Eldred dissent, the originalist analysis embodies the historical approach of the IP Restrictors. His analysis rested not on specific statements from the Philadelphia convention or the ratification debates, but on the conception that the Founders were firmly opposed to monopolies and that English experience with respect to copyright centrally informed the original understanding of the Copyright Clause. As he wrote, "Madison, like Jefferson and others in the founding generation, warned against the dangers of monopolies." 152 According to Justice Breyer, in accordance with its "basic purpose... as understood by the Framers and by this Court... [t] he [Copyright] Clause assumes an initial grant of monopoly, designed primarily to encourage creation, followed by termination of the monopoly grant in order to promote dissemination of already-created works." 153

While the majority opinion did not address the petitioners' public choice arguments explicitly, it did offer a response to those who see CTEA as Congress succumbing to rent-seeking behavior by copyright holders. The Supreme Court found a host of justifications for this legislation-beyond those identified above in our discussion of the economic-utilitarian justification for copyright. The Court observed that "[i]n addition to international concerns, Congress passed the CTEA in light of demographic, economic, and technological changes, and rationally credited projections that longer terms would encourage copyright holders to invest in the restoration and public distribution of their works." 154

Both of the dissents in Eldred reflect a strong conception of judicial oversight of the political process. This oversight was needed due to the CTEA's flaws. For Justice Stevens, the Copyright Clause embodied the policy goal of "encouraging new works and adding to the public domain." 155 But the CTEA amounted to no more than a "gratuitous transfer of wealth" to favored "authors, publishers, and their successors in interest." 156 For Justice Breyer as well, the CTEA was special-interest

and the concept of using patent precedents so heavily in the copyright context. See Eldred, 123 S. Ct. at 779 n.7 ("Graham involved no patent extension."); id. at 787-88 (distinguishing copyright from patent, and discussing the different quid pro quo at stake in each area).

150. Eldred, 123 S. Ct. at $798-99$ (Stevens, J., dissenting).

151. Id.

152. Id. at 803 (Breyer, J., dissenting).

153. Id. at 810 .

154. Id. at 782 (footnotes omitted).

155. Id. at 793 (Stevens, J., dissenting).

156. Id. 
legislation, and one in which he failed to find "any constitutionally legitimate, copyright-related way" the public would benefit. ${ }^{157}$ Justice Stevens, like the petitioners, saw the Copyright Clause as embodying particular policy ends: "encouraging new works and adding to the public domain." ${ }^{58}$ Retroactive copyright extension failed to pass constitutional muster because it involved aiding private parties, rather than the public good: "Ex post facto extensions of copyrights result in a gratuitous transfer of wealth from the public to authors, publishers, and their successors in interest. Such retroactive extensions do not even arguably serve either of the purposes of the Copyright/Patent Clause." 159

Justice Breyer similarly found the CTEA to be special-interest legislation and rejected it on those grounds. He wrote:

It is easy to understand how the statute might benefit the private financial interests of corporations or heirs who own existing copyrights. But I cannot find any constitutionally legitimate, copyright-related way in which the statute will benefit the public. Indeed, in respect to existing works, the serious public harm and the virtually nonexistent public benefit could not be more clear.

... This analysis leads inexorably to the conclusion that the statute cannot be understood rationally to advance a constitutionally legitimate interest. ${ }^{160}$

On this reasoning, Breyer rejected the CTEA as the result of the worst kind of rent-seeking. Thus, like Stevens, Breyer saw the CTEA as suspect legislation that transferred wealth to favored parties without a benefit to the public at large.

Finally, Justice Ginsburg's majority opinion rejected Eldred's call for heightened review, finding that rational basis review was appropriate and that the CTEA passed this standard. As we have already discussed, Justice Ginsburg noted that the petitioners urged the Court to apply a "congruence and proportionality" standard in evaluating Congress's power under Section 5 of the Fourteenth Amendment but found that standard inapplicable "for judicial review of legislation enacted, as copyright laws are, pursuant to Article I authorization." 161 Unlike the Fourteenth Amendment, which authorizes Congress to enforce its commands, the Copyright Clause "empowers Congress to define the scope of the substantive right."162 The

157. Id. at 813 (Breyer, J., dissenting).

158. Id. at 793 (Stevens, J., dissenting).

159. Id.

160. Id. at 813 (Breyer, J., dissenting).

161. Id. at 788 .

162. Id. 
Court stated that "[j]udicial deference to such congressional definition" was "a corollary to the grant of Congress of any Article I power.",163 Justice Ginsburg therefore embraced rational basis scrutiny, stating her conviction simply that "the CTEA is a rational enactment; we are not at liberty to second-guess congressional determinations and policy judgments of this order, however debatable or arguably unwise they may be."164

Justice Ginsburg adopted this rational basis test without explaining why she did so. She supported her rational basis test with a citation to three cases: Stewart v. Abend, ${ }^{165}$ Sony v. Universal Studios, ${ }^{166}$ and Graham v. Deere. ${ }^{167}$ Yet, these decisions, while involving judicial deference to Congress, were not cases in which the rational basis test was explicitly applied. ${ }^{168}$

The two dissenters also endeavored to define the appropriate standard of review. For Justice Stevens, there was no need "to determine whether the deference that is normally given to congressional policy judgments may save from judicial review its decision respecting the appropriate length of the term." 169 In his opinion, the only question before the Court concerned "Congress' power to extend retroactively the terms of existing copyrights." 170 Stevens argued that the Court should adopt a bright-line rule, or, in his words, "a categorical rule prohibiting retroactive extensions" 171 in order to "effectively preclude perpetual copyrights." 172 Opting for a bright-line test (i.e., no retroactive extension) allowed Stevens to reserve the determination of the appropriate standard of review for another day.

163. Id. (quoting Graham v. John Deere Co. of Kansas City, 383 U.S. 1, 6 (1966)).

164. Id. at $782-83$.

165. 495 U.S. 207, 217 (1990) (examining "the language of and case law interpreting" a section of the Copyright Act).

166. 464 U.S. 417 (1984) (involving a claim that the Court decided would serve to expand copyright privilege beyond the language of the Copyright Act).

167. 383 U.S. 1 (1966) (considering the meaning of a provision of the Patent Act pertaining to nonpatentability of an invention because of its obviousness). Ginsburg cites these cases in Eldred. 123 S. Ct. at 785.

168. The first two cases simply involved cases of statutory interpretation in which the Court decided that it was not willing to consider any larger policy issues underlying the Copyright Act. See Stewart, 495 U.S. at 228 (holding that policy arguments regarding matters underlying the Copyright Act are "better addressed by Congress than the courts"); Sony, 464 U.S. at 432 ("In a case like this, in which Congress has not plainly marked our course, we must be circumspect in construing the scope of rights created by a legislative enactment which never contemplated such a calculus of interests."). As for Graham, the Court decided that the effect of the 1952 Patent Act was to codify longstanding judicial precedents rather than to alter the general level of innovation required to sustain patentability. 383 U.S. at $3-4,17$. The issue of the proper level of scrutiny in assessing the constitutionality of copyright or, more generally, intellectual property legislation did not arise in any of these cases.

169. Eldred, $123 \mathrm{~S}$. Ct. at 800 (Stevens, J., dissenting).

170. Id.

171. Id.

172. $I d$. 
Justice Breyer, on the other hand, employed a balancing approach that assessed the respective costs and benefits to authors and to the public in copyright extension. As the majority opinion noted, Justice Breyer's target was not merely retrospective extensions of copyright, but the future extensions of the CTEA as well. ${ }^{173}$ Breyer called for a reading of the Copyright Clause and First Amendment in tandem and adoption of the following approach: "I would review plausible claims that a copyright statute seriously, and unjustifiably, restricts the dissemination of speech somewhat more carefully than reference to this Court's traditional Commerce Clause jurisprudence might suggest." petitioners' request for a search for "congruence and proportionality," he stated that the CTEA "involves not pure economic regulation, but regulation of expression, and what may count as rational where economic regulation is at issue is not necessarily rational where we focus on expression." ${ }^{175}$ In summary, Breyer stated his test in this (somewhat unwieldy) language: "I would look harder than does the majority at the statute's rationality - though less hard than precedent might justify." 176 "[V]igilance is all the more necessary," Justice Breyer wrote, "in a new Century that will see the intellectual property rights and the forms of expression that underlie them play an ever more important role in the Nation's economy and the lives of its citizens.",177

Breyer noted further that the CTEA statute represented a billion dollar transfer to existing copyright holders "from those who wish to read or see or hear those classic books or films or recordings that have survived."178 Balanced against these costs, Breyer found no adequate copyright-related benefit to support the CTEA. To begin with, few books or other creative works retain any value within the zone of the CTEA extension. ${ }^{179}$ Moreover, since the CTEA's new royalties to heirs vest only in the relatively distant future, Breyer drew on assumptions about the time value of money combined with the low percentage chance of creating such a classic. As Breyer did the arithmetic, "a $1 \%$ likelihood of earning $\$ 100$ annually for 20 years, starting 75 years into the future, is worth less than seven cents today."180 Breyer's financial advice to the "potential

173. Id. at 775 n. 1,778 n. 4 .

174. Id. at 802 (Breyer, J., dissenting),

175. Id.

176. Id. (citing City of Cleburne v. Clebume Living Ctr., Inc., 473 U.S. 432, 446-50 (1985), Plyler v. Doe, 457 U.S. 202, 223-24 (1982), and Dep't of Agric. v. Moreno, 413 U.S. 528, 534-38 (1973)).

177. Id. at 812 .

178. Id. at 804 .

179. As Breyer stated, "No potential author can reasonably believe that he has more than a tiny chance of writing a classic that will survive commercially long enough for the copyright extension to matter." Id. at 807 .

180. Id. 
Shakespeare, Wharton, or Hemingway" was to put "a few dollars into an interest-bearing bank account." ${ }^{, 181}$ Implicit in this advice is a judgment by Breyer about how copyright law may or may not motivate authors-the only permissible motivation is one that is economically rational. ${ }^{182}$ In conclusion, Breyer found "no legitimate, serious copyright-related justification for this statute." 183

\section{The Eldred Opinion and Unresolved Questions of the Constitution's Treatment of Intellectual Property}

With its 7-2 majority, Eldred may initially seem to have shut the door on the constitutional agenda of the IP Restrictors. The Court clearly rejected Eldred's argument to read a bright-line test into the Copyright Clause barring retroactive extension. More broadly, the Court stated that Congress's decisions under the Copyright Clause should be subject to rational basis review by the judiciary. Yet, the Eldred decision should not be seen as ending the debate over the constitutional status of intellectual property. Indeed, we think that this debate will continue for five reasons.

First, the Eldred decision in many ways is inadequately theorized and no extended piece of scholarship to date has supported the position that the Court advances. Justice Ginsburg does not go into extensive detail regarding certain aspects of her argument, and no one else has offered a solid theoretical or historical basis for the result she embraces. Ginsburg did not provide a deep reading of the background or history of the Copyright Clause, and thereby left herself open to a double rejoinder by Justice Stevens: (1) The actual history of congressional practice was more complex than the Eldred majority indicated, ${ }^{184}$ and (2) since Marbury $v$. Madison, it has been "emphatically the province and duty of the judicial department to say what the law is." 185

181. Id.

182. It may be, however, that would-be authors of classic works, like most people, are motivated by irrational forces in their judgments. An entire new field of law and economics even looks at the widespread impact of limited, or "bounded," rationality on human decisionmaking. For a concise introduction, see David M. Kreps, Bounded Rationality, in 1 PALGRAVE DICTIONARY, supra note 57 , at $168,168-69$. Suffice it only to say that authors may well not follow the same purely rational calculus as Breyer. Indeed, his analysis of the nature of authors' psyche is precisely the kind of issue that judges are not well-situated to address in the real world.

Breyer also went into considerable detail to refute the claim that the CTEA achieved harmonization with EU law. In his judgment, the CTEA provided at best "partial future uniformity" that would lead to "comparative pennies" for authors. Eldred, $123 \mathrm{~S}$. Ct. at 809 (Breyer, J., dissenting).

183. Id. at 812 .

184. See id. at 793-99 (Stevens, J., dissenting)

185. Id. at 801 (quoting Marbury v. Madison, 5 U.S. (1 Cranch) 137, 177 (1803)). Stevens also pointed to the Court's decision in the "legislative veto" case, INS v. Chadha, which, according to Justice White's dissent, voided nearly 200 statutory provisions, 462 U.S. 919,967 (1983) (White, J., dissenting). Eldred, 123 S. Ct. at 797 (Stevens, J., dissenting). 
Second, at critical moments, the Court either accepted a part of the IP Restrictors' arguments or simply demurred to it. Justice Ginsburg's opinion accepted the view that the 1790 Copyright Act preempted state copyrights. The Court also apparently accepted the IP Restrictors' view that the Founders were antimonopolists, ${ }^{186}$ as well as the basic quid pro quo argument because there had been an exchange in this case. ${ }^{187}$ The Court further noted that the CTEA's legislative background supported the IP Restrictors' platform; Congress had always included existing copyright holders when it extended copyright terms. ${ }^{188}$

Third, despite the seemingly solid 7-2 vote, this opinion may well prove unstable as a precedent. This suggestion may initially seem both surprising and improbable: In a judicial age of plurality opinions and 5-4 decisions, what could be more decisive than a 7-2 Supreme Court opinion?

With only one opinion for the majority, however, we cannot know if future divisions exist among the seven justices who signed on to Justice Ginsberg's opinion. But it is striking that five of the majority votes came from Justices who have read constitutional grants of power to Congress narrowly in the past. Eldred might have been the case in which the Court extended its strict construction of Congress's Article I powers beyond the Commerce Clause. Nevertheless, in Eldred, Justices Kennedy, O'Connor, Rehnquist, Scalia, and Thomas did not deem it necessary to police congressional exercise of the enumerated power and did not write to distinguish this case from previous decisions that did find this obligation.

Many observers have noted this inconsistency in the decision of "the silent five." ${ }^{89}$ Writing in the middle of the night after the Court's decision was announced, Lessig wondered how the Chief Justice could not see the link between Lopez and Morrison, on one hand, and Eldred, on the other. ${ }^{190}$ "Did the Chief really not understand that this case was his case? That it was because of the principles that he had first articulated that we had spent four years litigating this case?" ${ }^{\prime 11}$ The editorial board of the Sacramento Bee also noted that "the five didn't peep," and questioned the Justices' unwillingness to allow Congress to bar firearms around schools or provide

186. For example, Justice Ginsburg distinguished the history confronted in England at the time of the Statute of Anne and its proposed amendment, and that faced by the Framers. She observed, "The Framers guarded against the future accumulation of monopoly power in booksellers and publishers by authorizing Congress to vest copyrights only in 'Authors."' Eldred, $123 \mathrm{~S}$. Ct. at 779 n.5.

187. Id. at 786 ("We can demur to petitioners' description of the Copyright Clause as a grant of legislative authority empowering Congress to 'secure a bargain-this for that."' (quoting Petitioners' Brief, supra note 34, at 16)).

188. Id. at 785-86.

189. Lawrence Lessig, The Silent Five (Jan. 16, 2003), at http://cyberlaw.stanford.edu/lessig/ blog/archives/2003_01.shtml\#.

190. Id.

191. Id. 
civil remedies to women who were victims of violence while "help[ing] Disney and other media giants [to] squeeze a few extra dollars out of halfcentury-old work at the expense of the public interest." 192

Regardless of the reason for the Court's decision, the Courts' inconsistent decisions suggest that the Eldred majority may be unstable. Should three of the silent five one day link this decision with their other case law, Eldred may fall as a precedent.

Fourth, the litigation agenda of the IP Restrictors will continue postEldred. In similar fashion to Eldred, these scholars have already instituted judicial proceedings challenging the constitutionality of a provision of the Uruguay Round Agreements Act (URAA), which extends copyright protection to certain foreign works that have fallen into the public domain. ${ }^{193}$ In title V, section 514 of the URAA, Congress removed certain foreign works still durationally eligible for U.S. copyright protection from the public domain. ${ }^{194}$ The plaintiffs in this case, Golan v. Ashcroft, argue that the Copyright Clause prohibits Congress from protecting such works on the grounds that the Intellectual Property Clause has a preemptive effect with respect to both the Foreign Commerce Clause and the Treaty Clause. ${ }^{195}$ They also make historical arguments similar to those advanced in Eldred and argue that Congress lacks power under the Copyright Clause to protect works that have entered the public domain. In their view, "The Framers did not sanction the removal of works from the public domain."196

Another challenge to copyright legislation may be on the horizon. Congressional attempts to extend quasi-property protection to databases have been questioned by an army of academic critics, who have argued that the Copyright Clause prevents Congress from exercising power that it would otherwise possess under the Commerce Clause. Indeed, the IP Restrictors' initial challenge to congressional authority in the intellectual property realm emerged in response to proposals in Congress throughout the 1990 s to provide protection for databases. Although those proposals have not yet been adopted, the scholarly literature on the topic is

192. Editorial, Mickey Mouse in Chains: Copyright Ruling Compromises Court, SACRAMENTO BEE, Jan. 27, 2003, at B4.

193. Uruguay Round Agreements Act, Pub. L. No. 103-465, § 514, 108 Stat. 4809, 4976 (1994). The critical portion of the law regarding foreign works in the public sphere is codified at 17 U.S.C. $\$ 104 \mathrm{~A}(2000)$.

194. $\$ 514,108$ Stat. at 4976 .

195. For more on Golan v. Ashcroft, see Berkman Ctr. for Internet \& Soc'y, Harvard Law Sch., Openlaw: Golan v. Ashcroft, at http://eon.law.harvard.edu/openlaw/golanvashcroft (last visited Apr. 15, 2003). The Golan briefs cited in this Essay are all posted at this site.

196. Plaintiff's Memorandum in Opposition to Defendant's Motion To Dismiss at 49, Golan v. Ashcroft (D. Colo. 2002) (No. 01-B-1854). As they state concisely, "The harm effectuated by copyright 'restoration' is precisely the kind of harm feared by the Framers." Id. at 51 . The "URAA purports to authorize precisely what the Framers intended to forbid-the removal of materials that have long before been enjoyed by the public." Id. at 52 . 
enormous. ${ }^{197}$ Moreover, the preemption argument mounted against the database proposals has been extended to attack statutes that have been enacted, and thus the critique of database proposals is simply one manifestation of the broader challenge to congressional authority. ${ }^{198}$

As the Golan litigation and the debate over database bills indicate, Eldred has not put an end to litigation in this area. Can Congress, in the course of implementing treaty obligations, extend copyright protection to works already in the public domain? Does the Intellectual Property Clause limit the scope of Congress's power under the Commerce Clause? Eldred raised the question whether the Court should construe the Copyright Clause in a way that narrowly constrains congressional power; these later cases also raise this fundamental question, but come at the question through issues not directly resolved in Eldred.

Similarly, the IP Restrictors will presumably advance additional claims in the years ahead. In particular, they did not advance the argument in Eldred that the Preamble of the Intellectual Property Clause is legally binding, so the issue was thus not before the Court. ${ }^{199}$ Some IP Restrictors have advanced the claim in their scholarship that the Preamble is binding and may well advance this claim in future litigation. ${ }^{200}$

There is a fifth and final reason why Eldred does not resolve all questions concerning the Constitution's treatment of intellectual property. Eldred may signal a move away from cases such as Feist, which offered a

197. For a sample of the literature, see Jane C. Ginsburg, Creation and Commercial Value: Copyright Protection of Works of Information, 90 COLUM. L. REV. 1865 (1990) [hereinafter Ginsburg, Creation and Commercial Value]; Jane C. Ginsburg, No "Sweat"? Copyright and Other Protection of Works of Information After Feist v. Rural Telephone, 92 COLUM. L. REV. 338, 367-74 (1992) [hereinafter Ginsburg, No "Sweat"?]; Heald \& Sherry, supra note 4, at 1176-79; Malla Pollack, The Right To Know?: Delimiting Database Protection at the Juncture of the Commerce Clause, the Intellectual Property Clause, and the First Amendment, 17 CARDozo ARTS \& ENT. L.J. 47, 55-66 (1999); J.H. Reichman \& Pamela Samuelson, Intellectual Property Rights in Data?, 50 VAND. L. REV. 51 (1997); and Philip H. Miller, Note, Life After Feist: Facts, the First Amendment, and the Copyright Status of Automated Databases, 60 FORDHAM L. REV. 507 (1991). For further discussion of the constitutional problems posed by database legislation, see Memorandum from Deputy Assistant Attorney General William Michael Treanor to Associate White House Counsel William Marshall on Constitutional Concerns Raised by the Collections of Information Antipiracy Act (July 28, 1998), 1998 OLC LEXIS 33.

198. The constitutional question raised by the database proposals is whether the Copyright Clause has a preemptive effect. Did the Clause bar Congress from using its Commerce Clause power to protect intellectual property if that intellectual property could not be protected under the Copyright Clause? The text of the Constitution itself does not provide such a preemptive effect for the Copyright Clause. Textually, the Clause is simply a grant of a limited power. The IP Restrictors argue, however, that the Clause has a broader significance. In their view, it means that Congress's only power in the realm of intellectual property is the power vested in it under the Copyright Clause.

199. Eldred v. Ashcroft, 123 S. Ct. 769, 784-85 (2003).

200. Indeed, amicus curiae "Eagle Forum" raised this argument before the D.C. Circuit in Eldred, claiming that " $[\mathrm{t}]$ he introductory language of the Copyright Clause defines, and therefore delimits, congressional power." Brief of Amicus Curiae Eagle Forum Education \& Legal Defense Fund at 3, Eldred v. Reno, 239 F.3d 372 (D.C. Cir. 2001) (No. 99-5430). 
narrow reading of the Copyright Clause in the context of the meaning of the term "authors." Feist narrowly read the term "authors" in the Copyright Clause as requiring original creations. The IP Restrictors have sought to build on Feist and obtain a narrow reading of "limited Times." It may be, however, that after Eldred, the Court, in construing the Intellectual Property Clause, will move in the other direction - it may revisit Feist and limit the reach of the originality requirement, or may reject it altogether. As a result, new challenges to existing case law may seek to build on Eldred.

The following two Parts approach the issue of the aftermath of Eldred in different ways, each drawing on a lesson of the famous Lochner case. Part IV considers the issues raised in Eldred from the vantage point of originalism. Part $\mathrm{V}$ then analyzes it from the broader perspective of constitutional history and structure. ${ }^{201}$

\section{THE COPYRIGHT ClAUSE, MONOPOLIES, AND ORIGINALISM}

The originalist claims advanced by the IP Restrictors and Eldred dissenters mirror those made by the champions of Lochner-era jurisprudence- - both with respect to their conception of the judicial role and with respect to their claim that the Founders were deeply opposed to monopolies. This Part shows that the IP Restrictors' originalist claims bear precisely the same fundamental flaws that troubled Lochner-era jurisprudence.

As discussed in Parts II and III, proponents of aggressive judicial review under the Copyright Clause claim that their position reflects the original understanding. Their historical argument is not grounded in classic originalist evidence, such as statements from the Constitutional Convention in Philadelphia or from the ratification debates. It is principally grounded, instead, in appeals to broad principles shared by the Founding generation. ${ }^{202}$ In particular, advocates of active judicial review, such as Benkler, Heald, and Sherry, have asserted that the Founders were deeply fearful of

201. This Essay does not address the First Amendment arguments addressed in Eldred. These arguments are beyond the scope of this Essay in part because they are analytically distinct from the claims under the Copyright Clause. Eldred's intellectual property claims do not have First Amendment resonance, but rather reflect the idea that the challenged legislation is invalid because it is rent-seeking. The petitioners' claims under the Copyright Clause also deserve separate analysis because these arguments have the potential to establish a very different kind of precedent than would have been established had Eldred's First Amendment arguments prevailed.

202. Our concern is not that the IP Restrictors appeal to the broad principles shared by the Founding generation. Proper recognition of broad principles is vitally important to understanding the Founders' purposes. See Martin S. Flaherty, History "Lite" in Modern American Constitutionalism, 95 COLUM. L. REV. 523, 554-55 (1995) (arguing that recognition of ideological paradigms is critical). As we will discuss, however, the IP Restrictors err regarding the nature of these broad principles. They posit a uniform opposition to monopolies and hostility to government intervention in the economy that is belied by the historical record. 
monopolies and intended to give Congress only a very limited power to create monopolies under the Copyright Clause. As the petitioners' brief in Eldred argued, "Nor is there any doubting the Framers' fear about the power that they were creating: the resolution against monopolies was as strong in the framing generation as in any time since; they, more than we, were keenly sensitive to the dangers of state-backed monopolies. ${ }^{, 203}$

Although they offer no statements from the Founders discussing how the English experience with monopolies shaped the scope of the Copyright Clause, IP Restrictors argue that the Clause must be read against the background of English history. As Heald and Sherry have argued, "The framers' awareness of the English experience that led to the Statute of Monopolies and the Statute of Anne, and their recognition of the very real cost of granting exclusive rights, drove their decision to prohibit Congress from treating favored interest groups like modem-day courtiers."204 According to the petitioners' brief in Eldred, "The Framers drafted the Copyright Clause against the background of English experience with monopolies in general, and with publishing monopolies in particular."205 The IP Restrictors portray the Framers' world as a world animated by fear of government aid to favored interest groups and infer that the modern Court must stop the government favoritism that the Founders opposed.

Both of the Eldred dissents incorporated the IP Restrictors' historical analysis. Like the IP Restrictors, Justice Breyer rests his claims on an originalist understanding that operates at a high level of generality:

This view of the [Copyright] Clause finds strong support in the writings of Madison, in the antimonopoly environment in which the Framers wrote the Clause, and in the history of the Clause's English antecedent, the Statute of Anne-a statute which sought to break up a publishers' monopoly by offering, as an alternative, an author's monopoly of limited duration. ${ }^{206}$

As will be shown hereafter, Madison's views-including his views in the essay on which Breyer relies-are more complicated than Breyer suggests. The critical point to recognize, however, is that Breyer, like the IP Restrictors, rests his claims on a view of original understanding that operates at a high level of generality.

Justice Stevens offers no support for his claim that the Founders were "familiar with this history." Significantly, he not only assumes familiarity,

203. Petitioners' Brief, supra note 34 , at 10.

204. Heald \& Sherry, supra note 4 , at 1169.

205. Petitioners' Brief, supra note 34, at 23-24.

206. Eldred v. Ashcroft, 123 S. Ct. 769, 810 (2003) (Breyer, J., dissenting). Madison's "detatched memoranda"- the work that Justice Breyer invokes here-is discussed infra notes 297-302 and accompanying text. 
but a high level of familiarity. As relevant British background, he focuses on the rationale offered in a published letter from 1735 that appeared as part of the successful opposition to an amendment to the Statute of Anne. ${ }^{207}$ It can hardly be assumed that the Founders both knew of British experience and political thought at this level of detail and were informed by more than half a century later. Given the paucity of evidence that Justice Stevens finds adequate to read an antimonopoly attitude into the original understanding, it appears that he, like Justice Breyer, believes that opposition to monopolies was a strong background understanding informing the Founders' views of copyright. $^{208}$

As Julie Cohen has pointed out, leading cyberlaw scholars have advanced a substantive vision of the proper scope of government regulation that, in its hostility to regulation and its strong commitment to freedom of contract, resembles the economic vision reflected in Lochner. ${ }^{209}$ But another link exists between the views reflected in recent intellectual property scholarship (as well as in Justice Breyer's and, to a lesser extent, Justice Stevens's dissents) and the views of the champions of Lochnerism, and it is a link that has not previously been recognized: The IP Restrictors, by asserting that their position is true to originalism, echo the originalist claims made by the proponents of Lochner-era jurisprudence.

Like modern champions of an expansive reading of the judicial role in interpreting the Copyright Clause, when judges and academics of the Lochner-era appealed to originalism, they did not place principal reliance on specific statements of the Founders. ${ }^{210}$ They sought "original intent, not in the intent of the Philadelphia convention, but in the traditions of the people as evidenced by their common law." ${ }^{111}$ More significant, one of the central background principles that supporters of Lochnerian jurisprudence read into the Constitution was hostility to legislation that, to use modern terminology, advanced the economic concerns of certain interest groups at

207. Eldred, 123 S. Ct. at $796 \&$ n. 9 (Stevens, J., dissenting).

208. Justice Stevens, unlike Justice Breyer, also advanced a traditional originalist argument. He contended that the first Congress's denial of a statute that would have permitted patents for imports reflected a strong conception among the Founders of the limits of the Intellectual Property Clause. See id. at 795. This position reflects a misunderstanding of the relevant history. We show infra Section IV.B that there was a range of opinions among the Founders about the proper scope of congressional power over intellectual property and that early practicc reflects a generous view of congressional power.

209. See Julie E. Cohen, Lochner in Cyberspace: The New Economic Orthodoxy of "Rights Management," 97 MICH. L. REV. 462, 464 (1998) (explaining that the economic vision of cyberlaw scholars was similar to that embodied in Lochner jurisprudence).

210. See Stephen A. Siegel, Lochner Era Jurisprudence and the American Constitutional Tradition, 70 N.C. L. REV. 1, 78-90 (1991) (discussing the nature of appeals to history by Lochner-era jurists). Indeed, in interpreting the phrase "due process," Lochner-era jurists saw themselves as "evolving" the "application of principles extant at the founding." Id. at 88.

211. Id. at 89. 
the expense of others. ${ }^{212}$ To a remarkable degree, Lochner-era judges made the same arguments now being made by today's IP Restrictors in calling for judicial activism to protect intellectual property.

The most striking examples of this parallelism are the dissents by Justices Bradley and Field in the Slaughter-House Cases, ${ }^{213}$ which are classic statements of the jurisprudence that the Court ultimately embraced in Lochner. ${ }^{214}$ The dissenters contended that the Court erred in failing to strike down a legislative grant to the Crescent City Livestock Landing and Slaughterhouse Company of the exclusive right to butcher animals in the New Orleans area, arguing that this legislation violated the Fourteenth Amendment's Privileges and Immunities Clause. Their analysis rested on the claim that the Clause should be understood to bar such monopolies.

The dissents present a series of historical claims about the granting of monopolies. One might easily imagine that the following quotation from Justice Bradley's dissent dates not from 1872, but from 2003. Bradley argues:

The granting of monopolies, or exclusive privileges to individuals or corporations, is an invasion of the right of others to choose a lawful calling, and an infringement of personal liberty. It was so felt by the English nation as far back as the reigns of Elizabeth and James. A fierce struggle for the suppression of such monopolies, and for abolishing the prerogative of creating them, was made and was successful. The statute of 21 st James, abolishing monopolies, was one of those constitutional landmarks of English liberty which the English nation so highly prize and so jealously preserve. It was a part of that inheritance which our fathers brought with them. This statute abolished all monopolies except grants for a term of years to the inventors of new manufactures. This exception

212. See Cass R. Sunstein, Lochner's Legacy, 87 CoLUM. L. REv. 873, 878 (1987) ("[T]he minimum wage statute [in Lochner] was invalidated as an interest-group deal, reflecting nothing other than political power."); G. Edward White, Revisiting Substantive Due Process and Holmes's Lochner Dissent, 63 BRoOK. L. REV. 87, 88 (1997) (asserting that Lochner-era due process decisions reflected "the principle that no legislature could enact 'partial' legislation, legislation that imposed burdens or conferred benefits on one class of citizens rather than the citizenry as a whole").

213. 83 U.S. (16 Wall.) 36 (1872).

214. The point that the Slaughter-House dissents by Justices Bradley and Field were foundational texts of Lochner-era jurisprudence is a common one. See, e.g., Kevin Christopher Newson, Setting Incorporationalism Straight: A Reinterpretation of the Slaughter-House Cases, 109 YALE L.J. 645, 665 (2000) ("In Slaughter-House, Justices Field, Bradley, and Swayne laid the intellectual foundation for the protection of economic rights through substantive due process doctrine, an approach that is most commonly associated with Lochner v. New York."); Richard Primus, Canon, Anti-Canon, and Judicial Dissents, 48 DUKE L.J. 243, 279 (1998) ("The Supreme Court decisions of the Lochner era ... made the dissents of Justices Joseph Bradley and Stephen Field [in Slaughter-House] appear prophetic."); Siegel, supra note 210, at 82, 90-92, 100 (explaining that the Bradley and Field dissents in Slaughter-House represent early manifestations of Lochner-era jurisprudence). 
is the groundwork of patents for new inventions and copyrights of books. These have always been sustained as beneficial to the state. But all other monopolies were abolished, as tending to the impoverishment of the people and to interference with their free pursuits. And ever since that struggle no English-speaking people have ever endured such an odious badge of tyranny. ${ }^{215}$

Justice Field's dissent presents a similar historically grounded argument, reading British opposition to royal grants of monopolies into the United States Constitution. ${ }^{216}$

To show how closely the IP Restrictors' historical claims mirror the historical claims of Lochner-era jurisprudence, one need only list the elements of Justice Bradley's argument. The English fiercely opposed the Crown's grants of monopolies and fought successfully against them. This commitment to freedom from monopolies is part of the American constitutional heritage. Patents and copyrights are the sole constitutionally sanctioned exception to the Founders' hostility to monopolies. But for the fact that Bradley was generally enthusiastic about patents and copyrights, the basic structure of his argument-and the suspicion about government intervention in the economy - could have featured in the Eldred petitioners' brief.

Ultimately, historical research led to two strong challenges to the accuracy of the originalist claims of Lochner jurisprudence. First, scholars showed that early coirts were deferential to legislative decisionmaking. Thus, it was shown that the Lochner era's aggressive judicial policing of legislation for constitutionality was a break with traditional conceptions of judicial review. The leading work advancing this position was James Bradley Thayer's classic article, The Origin and Scope of the American

215. Slaughter-House Cases, 83 U.S. (16 Wall.) at 120 (Bradley, J., dissenting).

216. Justice Field wrote:

The common law of England is the basis of the jurisprudence of the United States. It was brought to this country by the colonists, together with the English statutes, and was established here so far as it was applicable to their condition. That law and the benefit of such of the English statutes as existed at the time of their colonization, and which they had by experience found to be applicable to their circumstances, were claimed by the Congress of the United Colonies in 1774 as a part of their "indubitable rights and liberties." Of the statutes, the benefits of which was thus claimed, the statute of James I against monopolies was one of the most important. And when the Colonies separated from the mother country no privilege was more fully recognized or more completely incorporated into the fundamental law of the country than that every free subject in the British empire was entitled to pursue his happiness by following any of the known established trades and occupations of the country, subject only to such restraints as equally affected all others. The immortal document which proclaimed the independence of the country declared as self-evident truths that the Creator had endowed all men "with certain inalienable rights, and that among these are life, liberty, and the pursuit of happiness; and that to secure these rights governments are instituted among men."

Id. at 104-05 (Field, J., dissenting) (footnote omitted). 
Doctrine of Constitutional Law. ${ }^{217}$ Thayer argued that the early view was that a court "can only disregard the Act when those who have the right to make laws have not merely made a mistake, but have made a very clear one,- so clear that it is not open to rational question.,"218 Thayer's article had an extraordinary influence on American constitutional history. Its argument for a limited conception of judicial review profoundly influenced Justices Holmes, Brandeis, and Frankfurter. ${ }^{219}$ In fact, Frankfurter described Thayer's article as the most important article ever written about American constitutional law. ${ }^{220}$ Second, scholars such as Louis Hartz ${ }^{221}$ and Oscar and Mary Handlin ${ }^{222}$ demonstrated that, from the time of the Revolution, state governments actively intervened in economic affairs. This work indicated that-contrary to the claims of Lochner jurisprudence-a laissez-faire conception of political economy was not the dominant view at the time of the Founding.

In this Part, we seek to develop a parallel critique of the IP Restrictors' new Lochnerism. We thus challenge the IP Restrictors' originalism on the same two grounds that scholars challenged the originalism of Lochner-era jurisprudence. First, drawing on modern scholarship concerning the original understanding of judicial review as well as original research, we argue that the exercise of judicial review was initially constrained. As a result, the IP Restrictors' originalist claims, which we discussed in Part I of this Essay, as well as the originalist accounts of Justices Breyer and Stevens, miss a critical step. Even if the Founders had believed that Congress's powers under the Copyright Clause were severely limited, they did not believe that courts should closely scrutinize legislation to determine whether Congress had stayed within those boundaries.

Second, we challenge the IP Restrictors' substantive vision of the original understanding of the Copyright Clause. Our basic point here is that the IP Restrictors-like the champions of Lochnerian jurisprudence-paint a false picture of the Founders' view of the legitimacy of governmental

217. James B. Thayer, The Origin and Scope of the American Doctrine of Constitutional Law, 7 HaRV. L. REV. 129 (1893).

218. Id. at 144 .

219. See Wallace Mendelson, The Influence of James B. Thayer upon the Work of Holmes, Brandeis, and Frankfurter, 31 VAND. L. REV. 71 (1978). It also profoundly influenced Judge Learned Hand. See Gerald GunTHER, LEARNEd HaND: THE MAN AND THE JUDGE 118-19 (1994) (discussing the effect of Thayer's article on Judge Hand's thought). But cf. Mark Tushnet, Thayer's Target: Judicial Review or Democracy?, 88 Nw. U. L. REV. 9,9 (1993) (noting that Thayer's conception of constrained judicial review did not apply to review of state statutes for consistency with the Federal Constitution).

220. See Felix Frankfurter, Felix Frankfurter Reminisces 299-301 (Harlan B. Phillips ed., 1960) (presenting Justice Frank furter's assessment of Thayer's article).

221. LOUIS HaRTZ, ECONOMIC POlicy and Democratic Thought: PenNSYlvania, $1776-1860$ (1948).

222. Oscar handlin \& Mary Flug handlin, Commonwealth: a Study of the Role OF GOVERNMENT IN THE AMERICAN ECONOMY: MASSACHUSETTS, 1774-1861 (1947). 
intervention in the economy. In particular, the early understanding was that Congress's powers under the Copyright Clause were expansive. Thus, the IP Restrictors are wrong about the original understanding at the levels of both broad principle and concrete application. Similarly, Justices Stevens and Breyer erred in their reading of the Founders' attitudes toward monopolies and offered flawed accounts of how the Copyright Clause was originally understood.

In her Eldred opinion, Justice Ginsburg also makes originalist arguments, as we do here. Her argument, however, was a much more limited one than ours. She invoked early retroactive extensions of patent protection by Congress (and the judicial opinions upholding them) as proof that the Founders thought retroactive extension consistent with the Copyright Clause. She also relied on the fact that the first Copyright Act protected previously existing works. ${ }^{223}$ While this evidence is important and will be discussed here, it is also of limited value. Justice Stevens offered two plausible responses to this evidence. First, he dismissed the retroactive extensions on the ground that the patents in question were for material in the public domain; thus, the statutes in question were "patentiy unconstitutional" under modern case law, and Justice Stevens therefore dismissed their significance. ${ }^{224}$ Second, he dismissed the 1790 copyright statute as irrelevant because Congress was creating, not extending, copyright protection. ${ }^{225}$ Neither argument is frivolous. To understand why the result in Eldred is the right one from the Founders' vantage point, it is necessary to place the issue in broader historical context.

\section{A. The Original Understanding of Judicial Review and Intellectual Property}

From the perspective of originalism, a claim that a court should invalidate a statute as exceeding the powers vested in Congress properly raises two questions. The first question, which we consider in this Section, regards the original understanding of the scope of judicial review to invalidate congressional statutes. The second question, which we consider in the next Section, concerns the scope of the power that the Founders intended to vest in Congress.

The IP Restrictors and the Eldred dissenters have utterly failed to consider the original understanding of judicial review. Their implicit assumption is that, if the CTEA is at odds with the best reading of the Copyright Clause, it follows that the Supreme Court should invalidate it.

223. Eldred v. Asheroft, 123 S. Ct. 769, 777-81 (2003).

224. Id. at 797 (Stevens, J., dissenting).

225. See id. at 795-96. 
Yet, as much a part of the original understanding as the substantive reading of any particular clause is the Framers' belief in judicial deference to Congress.

The leading modem scholarly work on the original understanding of judicial review is Sylvia Snowiss's influential Judicial Review and the Law of the Constitution. ${ }^{226}$ Snowiss argues that, in theory and in practice, the exercise of judicial review in the years before Marbury (as well as in Marbury itself) was limited to "the concededly unconstitutional act."227 As Snowiss recognizes, ${ }^{228}$ her conclusion echoes that reached by Thayer. ${ }^{229}$ Gordon Wood, the most influential constitutional historian of the Founding period, has embraced Snowiss's approach substantially. Wood has argued that judicial review was first seen as "a quasi-revolutionary process",230 and that, even as it won acceptance in the 1790s, its champions recognized that it "was not to be exercised in doubtful cases of unconstitutionality",231 and was to be "invoked only on the rare occasions of flagrant and unequivocal violations of the Constitution."232 Robert Clinton has advanced a similar view. ${ }^{233}$ In a related vein, David Currie and William Casto have concluded that the early Supreme Court case law reflects the view that only clearly unconstitutional statutes were to be invalidated. ${ }^{234}$

This historical work has come to influence modern legal discourse. Most notably, in his recent Harvard Foreword, ${ }^{235}$ Larry Kramer draws on this literature to critique on originalist grounds such Rehnquist Court opinions as Kimel v. Florida Board of Regents ${ }^{236}$ and United States v. Morrison. ${ }^{237}$ Kramer has argued that the original understanding was that judicial review was "a power to be employed cautiously, only where the

226. SYLVIA SNOWISS, JUDICIAL REVIEW AND THE LAW OF THE CONSTITUTION (1990).

227. Id. at 35 .

228. See id. at 6 n.7.

229. See supra text accompanying notes $217-218$.

230. Gordon S. Wood, The Origins of Judicial Review Revisited, or How the Marshall Court Made More out of Less, 56 WASH. \& LEE L. REV. 787, 796 n.41 (1999) (citing Sylvia Snowiss's analysis regarding the character of judicial review).

231. Id. at 799 .

232. Id. at 798-99.

233. See ROBERT LOWRY CLINTON, MARBURY $v$. MadisON AND JUdICIAL REVIEW 72-73 (1989) (arguing that the original conception of judicial review was narrow in scope).

234. William Casto, The Supreme Court in the Early Republic: The Chief JUSTICESHIPS OF JOHN JAY AND OLIVER ELLSWORTH 227 (1995) ("[T]he fundamental interpretive corollary of judicial review [was that] only legislation that was unconstitutional beyond doubt should be declared void."); DAVID P. CURRIE, THE CONSTITUTION IN THE SUPREME COURT: THE FIRST HUNDRED YEARS, 1789-1888, at 55 (1985) (suggesting that a "lasting principle[] of construction [was] established before 1801" that "doubtful cases were to be resolved in favor of constitutionality").

235. Larry D. Kramer, The Supreme Court, 2000 Term-Foreword: We the Court, 115 HARV. L. REV. 4 (2001).

236. 528 U.S. $62(2000)$.

237. 529 U.S. 598 (2000). 
unconstitutionality of a law was clear beyond doubt, ${ }^{, 238}$ and that the Supreme Court in recent years has dramatically departed from this approach even as it claims originalist sanction.

In short, the scholarly orthodoxy is that the original understanding was that courts deferred to Congress and legislatures unless a statute's unconstitutionality was clear. ${ }^{239}$ Examination of the early case law, however, reveals a subtler picture than that embodied in the leading scholarship. Nonetheless, in the context of the CTEA, this examination leads to the same conclusion as the scholarly orthodoxy. ${ }^{240}$

A surprisingly large body of case law exists from the period between the Declaration of Independence and Marbury v. Madison ${ }^{241}$ in which state or federal courts invalidated statutes, but these cases uniformly fall into limited categories. The nature of these categories indicates that state legislatures and Congress had broad discretion to make constitutional judgments - except when statutes trenched on the powers of governmental entities that did not have a role in adopting those statutes.

There are seven cases from the Revolutionary era in which courts arguably invalidated statutes. ${ }^{242}$ (Given the scholarly record, there is dispute as to which of these cases involved exercises of judicial review and which involved statutory construction. $)^{243}$ All of these cases involved statutes that

238. Kramer, supra note 235 , at 79 . At the same time, Kramer's vision of early judicial review is less constrained than Snowiss's approach. Thus, Kramer recognizes that in determining what was unconstitutional beyond a reasonable doubt, judges "were not confined strictly to the text but could draw on well-established principles of the customary constitution as well." Id. For Kramer's most detailed discussion of Snowiss's work, see $i d$. at 33 n.114.

239. While the view that the early exercises of judicial review were limited to the concededly unconstitutional case is the dominant view among modern scholars, it is not uniformly held. In particular, Suzanna Sherry has argued for the presence of a natural law strain in the early exercises of judicial review. Suzanna Sherry, The Founders' Unwritten Constitution, 54 U. CHI. L. REV. 1127 (1987). Professor Sherry's evidence of a natural law strain postdating the Constitution is limited, however. In particular, the Supreme Court did not rely exclusively on natural law as the basis for deciding any of the cases that Sherry discusses.

240. The analysis of the early case law is drawn from William Michael Treanor, Judicial Review Before Marbury: Policing Boundaries (Jan. 30, 2003) (unpublished manuscript, on file with authors).

241. 5 U.S. (1 Cranch) 137 (1803)

242. Symsbury Case, 1 Kirby 444 (Conn. Super. Ct. 1785) (statute resolving a land dispute); "Ten-Pound Act" Cases (N.H. 1786), described in 2 WILLIAM WINSLOW CROSSKEY, POLITICS AND THE CONSTITUTION IN THE HISTORY OF THE UNITED STATES 969-71 (1953) (statute limiting jury trial invalidated by two courts); Holmes v. Walton (N.J. 1780), described in Austin Scott, Holmes v. Walton: The New Jersey Precedent, 4 AM. HIST. REV. 456 (1899) (statute limiting jury trial); Rutgers v. Waddington (N.Y. City Mayor's Ct. 1784), reprinted in 1 JULIUS GoEBEL JR., THE LAW PRACTICE OF ALEXANDER HAMILTON: DOCUMENTS AND COMMENTARY 393 (1964) (statute affecting pleading and admissibility of evidence); Bayard v. Singleton, 1 N.C. 5 (1 Mart. 48) (1787) (statute limiting jury trial); Trevett v. Weeden (R.I. 1786), described in JAMES M. VARNUM, THE CASE, TREVETT V. WEEDEN: ON INFORMATION AND COMPLAINT, FOR REFUSING PaPer Bills in PAyment For BUtcher's MEat, nN MARKeT, at PAR WITH SPECIE (Providence, John Carter 1787), reprinted in 1 BERNARD SCHWARTZ, THE BILL OF RIGHTS: A DOCUMENTARY HISTORY 417,425 (1971) (statute limiting jury trial).

243. For a discussion of that debate, see CLINTON, supra note 233, at 48-55. 
either limited the right to a jury trial or that in some way affected judicial authority, such as by resolving a dispute between parties or by altering the evidentiary or pleading rules. There are eleven state court cases in the years before Marbury in which courts invalidated statutes. Like the Revolutionary-era cases, these cases all involved either jury trial rights or statutes that affected judicial authority. ${ }^{244}$

Federal circuit courts in this same period struck down six state statutes on a range of grounds. Three statutes in which state legislatures had exercised what could be considered judicial authority were struck down on state constitutional law grounds. Three other state statutes were struck down as violative of the federal Contract Clause, the Foreign Commerce Clause, and the Supremacy Clause, respectively. ${ }^{245}$ In addition, a federal circuit court pronounced invalid on separation-of-powers grounds a federal statute that vested in the circuit court the power to review pension applications, subject to review by Congress and the Secretary of War. ${ }^{246}$

244. Caldwell v. Commonwealth, $2 \mathrm{Ky}$. (Sneed) 129 (1802) (statute creating penalties for court clerks); Enderman v. Ashby, $2 \mathrm{Ky}$. (Sneed) 65 (180l) (jury trial); Stidger v. Rogers, $2 \mathrm{Ky}$. (Sneed) 64 (1801) (jury trial); Jenness v. Seavey (N.H. 1799), described in Merrill v. Sherburne, 1 N.H. 199, 216-17 (1818) (statute overturning a trial court decision); Butterfield v. Morgan (N.H. 1797), described in Merrill, I N.H. at 216-17 (same); Chickering v. Clark (N.H. 1797), described in Merrill, I N.H. at 216-17 (same); Gilman v. McClary (N.H. 1791), reprinted in Walter F. Dodd, Gilman v. McClary: A New Hampshire Case of I791, 12 AM. HIST. REV. 348, 350 (1907) (same); Taylor v. Reading (N.J. n.d.), described in State v. Parkhurst, 9 N.J.L. 427, 444 (1802) (ex post facto law); Austin v. Trs. of the Univ. of Pa., 1 Yeates 260 (Pa. 1793) (legislative resolution of a private land dispute); Bowman v. Middleton, 1 Bay 252 (S.C. 1792) (invalidating a statute because it denied a jurry trial and because it was a legislative resolution of a dispute between parties); Kamper v. Hawkins, 3 Va. (1 Va. Cas.) 20, 21, 67 (1793) (invalidating a statute assigning general court judges responsibility to sit as district court judges and giving district courts the power, previously assigned only to the chancery court, to issue injunctions).

245. Ogden v. Witherspoon, 18 F. Cas. 618 (C.C.D.N.C. 1802) (No. 10,461) (holding that an earlier state statute resolving the legality of a statute was unconstitutional under the state constitution); Pettibone ex dem. the Selectmen of Manchester (C.C.D. Vt. 1797), described in Church Land Cause Decided, FARMERS' MUSEUM, OR LAY PREACHER'S GAZETTE (Walpole, N.H.), Apr. 29, 1799, at 3 (invalidating a state takings clause); Van Home's Lessee v. Dorrance, 2 U.S. (2 Dall.) 304 (C.C.D. Pa. 1795) (No. 16,857) (holding a statute that resolved competing land claims unconstitutional under the state constitution); Champion \& Dickason v. Casey (C.C.D.R.I. 1792) (copy of original court record on file with authors; newspaper account in COLUMBIAN CENTINEL, June 20, 1792) (holding a statute invalid under the federal Contract Clause); Skinner v. May (C.C.D. Mass. 1794), described in JULIUS GOEREL, JR., 1 HISTORY OF THE SUPREME COURT OF THE UNITED STATES: ANTECEDENTS AND BEGINNINGS TO 1801, at 589-90 (1971) (determining that a state statute affected foreign commerce and was therefore unconstitutional on Foreign Commerce Clause grounds); Hamilton v. Eaton, 11 F. Cas. 336 (C.C.D.N.C. 1792) (No. 5980) (holding a state statute inconsistent with a treaty and therefore invalid on Supremacy Clause grounds).

246. Hayburn's Case, 2 U.S. (Dall.) 409, 410 (1794). The Supreme Court never reached the merits of the case because, by a divided vote, the Court did not allow Attomey General Randolph to make a motion for mandamus. Id. at 409 . While the published opinion is unclear, the basis for the Court's action was the determination that the Attorney General had to receive executive approval for his appearance. See Maeva Marcus \& Robert Teir, Hayburn's Case: $A$ Misinterpretation of Precedent, 1988 WIS. L. REV. 527. For further discussion, see 6 THE DOCUMENTARY HISTORY OF THE SUPREME COURT OF THE UNITED STATES, 1789-1800, at 33-45 (Maeva Marcus ed., 1998). 
The United States Supreme Court invalidated one statute on Supremacy Clause grounds-a Revolutionary War-era state statute allowing individuals who owed debts to enemy aliens to escape liability by paying money into the state treasury. ${ }^{247}$

Thus, the early cases in which statutes were invalidated involved only statutes that limited jury trials, statutes that affected judicial authority, or state statutes that were inconsistent with the Federal Constitution. In these areas, courts were frequently not deferential. Many of the statutes invalidated could plausibly have been upheld. ${ }^{248}$ There are numerous statements from this period suggesting that courts in the exercise of judicial review should be deferential to legislative decisions, ${ }^{249}$ but, in the specific areas noted, the practice was different. Outside of these three areas, however, courts were quite deferential-not invalidating a single statute. Thus, the early case law can be understood as embodying what can be styled as a "departmental view" of judicial review. Courts could act aggressively to protect governmental entities not involved in enacting a statute that affected them. They protected juries and the judiciary itself. They also protected the national government from state statutes that were seen as undercutting the authority of the national government. Beyond these very limited areas, however, courts applied a standard of review so permissive that no statute was ever invalidated.

This Essay is not the place for a resolution of the question whether the view of judicial review articulated here or the dominant view espoused by scholars such as Snowiss is correct. ${ }^{250}$ The critical point is that-in the context of the CTEA and, more broadly, legislation enacted under the Copyright Clause-they lead to the same result. Intellectual property legislation such as the CTEA does not encroach upon the authority of a government entity unrepresented in the political process (such as juries or

247. Ware v. Hylton, 3 U.S. (3 Dall.) 199 (1796).

248. See, e.g., William N. Eskridge, Jr., All About Words: Early Understandings of the "Judicial Power" in Statutory Interpretation 1776-1806, 101 COLUM. L. REV. 990, 1063 (2001) (noting that in Ware "the Court stretched the words of a treaty to carry out its goals and to establish an important national policy"); Mark Tushnet, Dual Office Holding and the Constitution: A View from Hayburn's Case, in ORIGINS OF THE FEDERAL JUDICIARY: ESSAYS ON THE JUDICIARY ACT OF 1789, at 196, 201 (Maeva Marcus ed., 1992) (noting that arguments relied on by the circuit court in Hayburn's Case were not "entirely well founded"). The claim that the early exercises of judicial review were not limited to cases of clear unconstitutionality is developed at much greater length in Treanor, supra note 240.

249. See, e.g., Cooper v. Telfair, 4 U.S. (4 Dall.) 14, 18 (1800) (Washington, J.) ("The presumption ... must always be in favor of the validity of laws ...."); Calder v. Bull, 3 U.S. (3 Dall.) 386, 399 (1798) (Iredell, J.) (“[T] he court will never resort to [its] authority, but in a clear and urgent case."); Hylton v. United States, 3 U.S. (3 Dall.) 171, 174 (1796) (Chase, J.) ("I will never exercise [the power of judicial review], but in a very clear case."); THE FEDERALIST NO. 78, at 396 (Alexander Hamilton) (Garry Wills ed., 1982) ("So far as they can by any fair construction be reconciled to each other; reason and law conspire to dictate that this should be done.").

250. For a more detailed presentation of the conception of the original understanding of judicial review outlined here, sce Treanor, supra note 240. 
courts). As a consequence, under the view advanced here, the original understanding would be that the standard of judicial review is a very deferential one. Under the dominant scholarly view, deference is appropriate here because the original understanding was that deference was always appropriate.

In arguing for their view of the original understanding of the congressional power, however, the IP Restrictors and the Eldred dissenters have completely overlooked the question of the original understanding of judicial power. This omission represents a fatal flaw in their reasoning. Even if one were to assume that, under the best reading of the Constitution, the CTEA-by extending copyright protection retrospectively-exceeded Congress's power, it is not clearly unconstitutional, and the IP Restrictors who attacked it were not claiming that it was. Rather, in Eldred, they made a number of subtle arguments about how to read the text: that a requirement of originality is implicit in the Copyright Clause; that the Preamble must be understood as legally binding, rather than a statement of general purpose; and that the Preamble provides a gloss on the words "limited Times."251 A similar comment can be made about the dissents in Eldred. Justices Breyer and Stevens, who so often have embraced deferential scrutiny of congressional legislation in other contexts, offer historical arguments in Eldred that wholly ignore the question of judicial role. But the Framers would have applied deferential scrutiny in this context, upholding a statute unless it was clearly unconstitutional.

We acknowledge that the argument we advance here is at odds with the Supreme Court's recent Commerce Clause and Fourteenth Amendment jurisprudence, which reflect a broad conception of judicial review. Our point in this Essay is not to challenge decisions such as Morrison and Lopez-decisions on which Eldred relied ${ }^{252}$-but to argue that concern for the original understanding mandates that aggressive judicial review should not be extended to a new area, the area of Congress's power under the Copyright Clause. As Justice Scalia has written, "Where originalism will make a difference is not in the rolling back of accepted old principles of constitutional law but in the rejection of usurpatious new ones."253

Nor do we concede that the IP Restrictors and the Eldred dissenters correctly conceptualize the original understanding of the scope of congressional power. As the next Section shows, the IP Restrictors are equally wrong on this point as well.

251. See supra text accompanying notes 104-107.

252. See Petitioners' Brief, supra note 34, at 13 (arguing that Morrison and Lopez are governing precedents concerning the interpretation of enumerated powers vested in Congress).

253. ANTONIN SCALIA, A MATTER OF INTERPRETATION: FEDERAL COURTS AND THE LAW 139 (1997). 


\section{B. The Original Understanding of Congressional Power Under the Copyright Clause}

The most relevant historical evidence directly bearing on the original understanding of the Copyright Clause can be summarized rapidly. There is little evidence from the Constitutional Convention. On August 18, 1787, James Madison proposed to his fellow delegates that Congress be empowered " $[t] 0$ secure to literary authors their copyrights for a limited time."254 In addition to this Copyright Clause, Madison may also have proposed a Patents Clause, although the record is confused. Madison's original notes record that he had proposed that Congress be empowered "[t]o secure to the inventors of useful machines and implements the benefits thereof for a limited time." ${ }^{255} \mathrm{He}$ subsequently revised his notes to conform to the official journal, ${ }^{256}$ which suggests that he did not make this proposal concerning patents. If Madison offered any rationale for his proposal or proposals, it is not recorded.

Charles Pinkney, speaking immediately after Madison, also recommended that Congress be empowered to establish copyrights: His suggestion was that Congress be empowered " $[t] 0$ secure to Authors exclusive rights for a certain time." ${ }^{257}$ Pinkney's proposal varies slightly from Madison's in a number of respects. It speaks of "Authors," not "literary authors." It gives these authors "exclusive rights," whereas Madison's proposal did not explicitly address whether the rights would be exclusive. Madison speaks of "a limited time," where Pinkney speaks of "a certain time." Although it is not clear whether Madison proposed a Patents Clause, it is clear that Pinkney did: He requested that Congress be empowered "[t]o grant patents for useful inventions." 258 There is no record of any speech from Pinkney explaining his recommendations.

The Copyright Clause in its current form was produced by the Committee of Eleven. The Clause's Preamble emerged first in this committee, and the remainder of the Clause seems to draw on both Madison's and Pinkney's proposals. Its reference to "limited Times" can be traced to Madison; its reference to "exclusive Right[s]" and "Authors" can be traced back to Pinkney's proposal. Because Madison (unlike Pinkney) was a member of the Committee, he is generally thought to be the Clause's author. No discussion of the Clause at the Philadelphia Convention was reported.

254. 2 THE ReCORdS OF the Federal CONVENTION of 1787, at 325 (Max Farrand ed., 1937) [hereinafter FARRAND].

255. 2 id. at 324 n.3.

256. See 2 id. (noting the revision). For the official journal, see $2 i d$. at 321.

257. $2 i d$ at 325 .

258. 2 id. 
Little discussion of the Clause occurred during the ratification process. In The Federalist No. 43, in commenting on the Clause, Madison briefly observed that the "utility of this power will scarcely be questioned." $259 \mathrm{He}$ added that " $[\mathrm{t}] \mathrm{h}$. public good fully coincides in both cases [of copyright and patent], with the claims of individuals. The States cannot separately make effectual provision for either of the cases, and most of them have anticipated the decision of this point, by laws passed at the instance of Congress." ${ }^{260}$ Madison did not explain why Congress only had the power to vest intellectual property rights for "limited Times," nor did he explain the significance of the Preamble. In a speech in North Carolina, Hugh Williamson stated that, while Congress would "have the power of protecting literary property," it would not be able to hamper "Liberty of the Press" because, in contrast to England before the Glorious Revolution, no power existed in the United States to bar unlicensed publication. ${ }^{261}$ In an essay arguing in favor of North Carolina's ratification, James Iredell pointed out that copyright protection would "give birth to many excellent writings which would otherwise have never appeared."262 In the Pennsylvania ratifying convention, Thomas McKean said that only the national government could adequately protect writings. ${ }^{263}$

These comments are all statements in support of the grant of congressional power, rather than explanations for why it was limited. The accent is on the positive. Nonetheless, critics of the constitutionality of the CTEA rely on the Founders' intent to support their position. As Eldred's supporters have put it, the Founders were committed to a rich public domain. ${ }^{264}$ Part of their argument is textual: The Founders' intent is evidenced by the fact that the text only confers on Congress a limited power. But the appeal to the Founding is also premised on evidence that is either outside of the Convention and ratifying debates, or statements from the debates about the Constitution that did not explicitly reference the Copyright Clause.

259. THE FEDERALIST No. 43 , supra note 249 , at 217 (James Madison).

260. Id. at 217-18.

261. Hugh Williamson, Speech at Edenton, N.C., N.Y. DAILY ADVERTISER, Feb. 25-27, 1788, reprinted in 16 THE DOCUMENTARY HISTORY OF THE RATIFICATION OF THE CONSTITUTION 201, 202 (John P. Kaminski \& Gaspare J. Saladino eds., 1986) [hereinafter DOCUMENTARY HISTORY].

262. James Iredell, Marcus $I V$, NORFOLK \& PORTSMOUTH J., Mar. 12, 1788, reprinied in 16 id. at 379,382 .

263. 2 THE DOCUMENTARY HISTORY OF THE RATIFICATION OF THE CONSTITUTION 415 (Mcrrill Jensen ed., 1976).

264. As a brief of fifty-three intellectual property professors stated, the Framers allowed the protection of copyright for a limited time "to ensure that the public will have unrestricted access to and use of protected writings and inventions at the expiration of a short period of exclusivity." Brief of Intellectual Property Law Professors as Amici Curiae Supporting Petitioners at 8, Eldred v. Asheroft, 123 S. Ct. 769 (2003) (No. 01-618). 
Thus, the IP Restrictors have pointed out that Jefferson opposed the Clause because he was opposed to monopolies of any type, ${ }^{265}$ and Justice Breyer similarly relies on Jefferson. A statement of Jefferson's (along with one of Madison's that will be subsequently discussed) is the only primary source invoked by Justice Breyer for the proposition that the Framers operated in an "antimonopoly environment." 266 Justice Breyer accurately captures Jefferson's sentiments. As Jefferson wrote in a letter to Madison:

[I]t is better ... to abolish ... Monopolies, in all cases, than not to do it in any.... The saying there shall be no monopolies lessens the incitements to ingenuity, which is spurred on by the hope of a monopoly for a limited time, as of 14. years; but the benefit even of limited monopolies is too doubtful to be opposed to that of their general suppression. ${ }^{267}$

In arguing for a limited congressional power under the Copyright Clause, Heald and Sherry have also invoked the fact that George Mason, in explaining his opposition to the Constitution, observed that "the congress may grant monopolies in trade and commerce" ${ }^{p 68}$ and the fact that a number of state ratifying conventions proposed amendments barring congressional grants of monopolies. ${ }^{269}$

Finally, scholars have argued that the Founders should be understood to have given Congress only a very constrained power to create intellectual property because the Founders wanted to avoid abuses similar to those that the Crown had committed in the sixteenth and seventeenth centuries. Specifically, the Founders knew that the Crown had issued patents that provided monopolies in established industries to crown favorites, and that the Crown had also used its control over licenses for publication to prevent dissent. Thus, the Founders are said to have sought to ensure that Congress would not be able to do the same thing. As Heald and Sherry have written:

The framers' awareness of the English experience that led to the Statute of Monopolies and the Statute of Anne, and their recognition of the very real cost of granting exclusive rights, drove their decision to prohibit Congress from treating favored interest groups like modern day courtiers. A retroactive grant of copyright

265. Heald \& Sherry, supra note 4 , at 1150.

266. Eldred, $123 \mathrm{~S}$. Ct. at 810 (Breyer, J., dissenting).

267. Letter from Thomas Jefferson to James Madison (July 31, 1788), in 13 THE PAPERS OF THOMAS JEFFERSON 440, 442-43 (Julian P. Boyd ed., 1956).

268. Heald \& Sherry, supra note 4, at 1150 (quoting The Objections of the Hon. George Mason, One of the Delegates from Virginia, in the Late Continental Convention, to the Proposed Federal Constitution, Assigned as His Reasons for Not Signing the Same, 2 AM. MUSEUM 534, $536(1787))$.

269. Id. 
protection cannot "promote the Progress of Science" in the way intended by the framers of the Constitution. ${ }^{270}$

And, as a consequence, Heald and Sherry see the CTEA as unconstitutional.

One problem with these arguments is that the evidentiary support is very thin. Proponents of this view do not offer any contemporaneous statements by the Founders linking concern over royal practice with the limits of the Copyright Clause. So, there is, for example, no particular reason to read into the Clause the view that the Founders were afraid that Congress would engage in the kind of giveaways in which Queen Elizabeth had once engaged. ${ }^{271}$

Moreover, invocation of Jefferson cannot count for much. Jefferson did not participate in either the Philadelphia convention or the Virginia ratifying convention. In his correspondence cited above, for that matter, Jefferson was expressing opposition to any congressional power to create intellectual property rather than support for the proposition that it should have a limited power to create intellectual property. Finally, Mason and others who attacked congressional powers to create monopolies were concerned with what they feared would be a broad implied congressional power under the Necessary and Proper Clause, rather than the express power to authorize patents and copyrights. ${ }^{272}$

270. Id. at 1169 .

271. We do not argue that the Founders were wholly unaware of English copyright history. That is clearly not the case. One can, for example, draw linkages between the first federal copyright statute and the Statute of anne. See LyMAN Ray PatTERSON, COPYRIGHT in HISTORICAL PERSPECTIVE 199-200 (1968) (discussing similarities). But the fact that the relevant British statute was apparently drawn on as a model does not mean that the Founders (including the members of the First Congress) embraced the worldview and the fears of those who adopted the earlier statute. Thus, many of the Founders were much more accepting of monopolies than the British are said to have been. See infra text accompanying notes 294-302. It is a mistake to read British opposition to monopolies into the Founders' vision. Also, even to the extent that the Founders drew on the Statute of Anne, it is not clear that they completely understood it. See PATTERSON, supra, at 200-01 (arguing that the drafters of the 1790 Act erroneously relied on provisions of the Statute of Anne in allowing piracy of foreign works and in protecting unpublished manuscripts, since they misunderstood the relevant provisions).

272. George Mason stated as one of his grounds for opposing the Constitution that "[u]nder their own Construction of the general Clause at the End of the enumerated Powers, the Congress may grant Monopolies in Trade \& Commerce." George Mason, Objections to the Constitution, VA. J., Nov. 22, 1788, reprinted in 8 DOCUMENTARY HISTORY, supra note 261 , at $40,45$. Professors Heald and Sherry read Mason's statement as an attack on the Copyright Clause and place great reliance on it as evidence of a "general skepticism about protecting intellectual property." See Heald \& Sherry, supra note 4, at 1149-50. Mason was not, however, expressing concern about the Copyright Clause, which appears in the middle of the enumerated powers, not at the end. "[T]he general Clause at the End of the enumerated Powers"- the subject of these comments-is the Necessary and Proper Clause. It is clear from Mason's statement itself that he is expressing his concern with the latter Clause and the potential breadth of powers the Clause conferred on Congress; he is not expressing concern about the Copyright Clause. See JOSEPH M. LYNCH, NEgotiatiNG THE CONSTITUTION: THE EARLIEST DEBates OVER ORIGINAL INTENT 31 (1999) (discussing Mason's statement as reflecting his concern about the Necessary and Proper Clause). We do not know of any instance in which Mason challenged the Copyright Clause. 
Equally significant, this weak evidence is advanced to support broad claims. In championing expansive judicial review, the IP Restrictors, the petitioners in Eldred, and the Eldred dissenters read the Copyright Clause in a way that sharply limits Congress's power to determine both (1) what is sufficiently original as to merit protection (a limitation that is particularly striking since the text does not make reference to originality), and (2) what is a limited time. The IP Restrictors and the Eldred petitioners also read the Clause in a way that makes the Preamble legally binding and that significantly constrains Congress's ability to determine what "Promote[s] the progress of Science and the useful arts."

Nonetheless, to argue that the originalist evidence concerning the Copyright Clause that the IP Restrictors and the Eldred dissenters have offered is weak is not, in and of itself, proof of any competing view of the Clause. The question remains of how, from an originalist perspective, the Clause should be understood. We now turn to this issue.

To understand the original meaning of the Clause, it is necessary at the start to place it in the context of the proceedings in Philadelphia. When the convention began, Governor Edmund Randolph of Virginia put forth the Virginia Plan, of which Madison was the principal author. The plan proposed a system of representation in Congress favorable to a prosperous state with a large population (such as Virginia): "[S]uffrage . . ought to be proportioned to the Quotas of contribution, or to the number of free inhabitants, as the one or the other rule may seem best in different cases.,2773 The plan also contemplated an expansive grant of power to Congress (which Madison had drafted): Congress's power would extend to "all cases to which the separate states are incompetent; or in which the harmony of the U.S. may be interrupted by the exercise of individual legislation."274 When the Framers reached the Great Compromise-under which each state would have equal representation in the Senate--the Virginians, whose power in Congress was diminished as a result of that compromise, reversed themselves on the appropriate scope of congressional power and argued for a series of more specific grants of power to Congress, rather than an openended grant. ${ }^{275}$

The question of formulating congressional powers fell to the Committee on Detail, which reached a compromise between the new Virginia model of limited and enumerated powers and the more open-ended grant of power, which was now championed by the small states. The Committee proposed a list of specific powers and, at the end of the list, it appended the Necessary and Proper Clause, which was, as Joseph Lynch

273. 1 FARRAND, supra note 254, at 20.

274, $1 \mathrm{id}$. at 17 .

275. 1 id. at 17-19. 
has convincingly argued, "deliberate[ly] ambigu[ous]." Founders clearly understood the Clause narrowly-as conferring upon Congress only the power to pass measures incidental to carrying out enumerated powers. Others understood it more broadly - as similar to the original grant of power under the Virginia Plan. ${ }^{277}$

Shortly before the Convention as a whole considered the Necessary and Proper Clause, Madison proposed the addition of a series of new congressional powers, and it is in this context that he proposed his Copyright Clause. Among the others were clauses empowering Congress to establish a university, to dispose of unappropriated lands, to procure lands for federal buildings within the states, to regulate Indian affairs, to establish temporary governments for new states, to create a district that would be the seat of national government, and "[t]o encourage by premiums \& provisions, the advancement of useful knowledge and discoveries."278 Probably the most consequential of the Clauses he proposed was a Corporations Clause: Congress would have had power to "grant charters of incorporation in cases where the Public good may require them, and the authority of a single State may be incompetent.",279

Madison appears to have acted in the belief that, in the absence of these specific grants of power, Congress could not carry out these goals. That is certainly the case with respect to the Corporations Clause, which is the clause about which we have the fullest evidence of Madison's views. After the Committee of Eleven rejected his proposal for a Corporations Clause, Madison brought it to the convention floor, where it was again rejected. Thereafter, in the debates in Congress in 1791 over whether Congress had the power to incorporate the Bank of the United States, Madison took the position that the Bank would be unconstitutional because Congress did not have the power under the Constitution to grant corporate charters. ${ }^{280} \mathrm{He}$ argued that the power to incorporate was not encompassed under the Necessary and Proper Clause because it was not incidental to an enumerated power. ${ }^{281}$

Thus, for Madison, the Corporations Clause he had proposed (and that his fellow Convention members had rejected) was quintessentially a grant of power, rather than a clarification of power already vested in Congress. The same would appear to have been true of the Copyright Clause, since it,

276. LYNCH, supra note 272 , at 21.

277. 1 FARRAND, supra note 254, at 17-22.

278. $2 \mathrm{id}$. at 325.

279. 2 id

280. See JaCk N. Rakove, ORIGINAL MEANINGS: Politics and IDEAS IN THE MAKING OF THE CONSTITUTION 352-55 (1996).

281. Id. at 352 . 
too, was not incidental to an enumerated power. ${ }^{282}$ Under Madison's interpretive approach, then, the Copyright Clause was necessary for Congress to create a statutory framework for the award of patents and copyrights.

This point is bolstered by Madison's view of the other clause analytically linked to the Copyright Clause: his clause empowering Congress "[t]o encourage by premiums $\&$ provisions, the advancement of useful knowledge and discoveries." Like the Corporations Clause, this provision was rejected by the Committee of Eleven and is not in the Constitution. In 1790, Tench Coxe devised a plan to encourage European inventors to bring their machines to the United States; the sale of national lands would fund the program. Madison wrote Coxe that Congress did not have the power to implement this plan, and he pointed to the failure of his "Premiums \& Provisions" Clause. "This fetter on the National Legislature tho' an unfortunate one, was a deliberate one," he wrote. ${ }^{283}$ Madison added, "The latitude of authority now wished for was strongly urged and expressly rejected., 284

Madison's response to Coxe's plan highlights the constrained nature of his view of enumerated powers. The Constitution explicitly gives Congress the "Power to dispose of and make all needful Rules and Regulations respecting the Territory or other Property belonging to the United States." 285 Congress cannot, however, use this power for "the advancement of useful knowledge and discoveries" because the Constitution did not sanction that end. This constrained view of the enumerated powers would, again, suggest that for Madison, the Copyright Clause was a grant of power that Congress would not have possessed but for that grant. In Eldred,

282. The Corporations Clause is also worth highlighting because analytically it is most similar to the Copyright Clause. The Copyright Clause is the only clause in the Constitution that allows Congress to create property rights. Had Madison's Corporations Clause been adopted, there would have been two clauses empowering Congress to create property rights. Moreover, while it has often been pointed out that the Copyright Clause is the only grant of power to Congress containing a preamble, Madison's Corporations Clause also contained language (although not in a preamble) linking the grant of power with a rationale. Congress could grant charters "where the Public good may require them" and where "the authority of a single State may be incompetent." 2 FARRAND, supra note 254 , at 325 . Madison, then, joined each of the two grants of power to create private property with a justificatory rationale.

283. RAKOVE, supra note 280 , at 355 (quoting Letter from James Madison to Tench Coxe, supra note 146 , at 128).

284. Id. (quoting Letter from James Madison to Tench Coxe, supra note 146, at 128). Rakove suggests that Madison was referring to his proposal to empower Congress to give away land in order to incentivize investors to bring their creations to America. Id.; see also 2 FARRAND, supra note 254 , at 324 (providing the text of Madison's proposal "[t]o dispose of the unappropriated lands of the U. States"). That proposal was adopted, however. See U.S. ConST. art. IV, \& 3, cl. 2. It seems clear that Madison was referring, instead, to the clause discussed in the text. For further discussion of Madison's response to Coxe's proposal, see Edward C. Walterscheid, Conforming the General Welfare Clause and the Intellectual Property Clause, 13 HARV. J.L. \& TECH. 87, 104-05 (1999).

285. U.S. CONST. art. IV, § 3, cl. 2. 
Justice Stevens relies on Madison's response to Coxe, but, because he does not understand the historical context, misreads it. According to Stevens, Madison was informing Coxe that his proposal was unconstitutional because it awards patent protection for inventions already created. ${ }^{286}$

Perhaps the best argument for a narrow view of Congress's power under the Copyright Clause is one that the IP Restrictors have not yet made. Their argument might be that their view is consonant with Madison's. This proposal would run: Madison thought that, but for the Copyright Clause, Congress would have no power to authorize patents or copyrights; the Copyright Clause is therefore the only source of authority for Congress to provide for patents and copyrights; and the grant should be read narrowly, in accordance with Madison's general interpretive approach. ${ }^{287}$

Even were one to accept the basic premise that Madison strictly construed grants of powers (and this is a fair reading of his constitutional methodology during this period), no reason exists to read into his view of the Copyright Clause the type of restrictions on congressional power that opponents of the CTEA propose. The twenty-year extension is a "limited Time[]." ${ }^{\text {288 }}$ Similarly, a plausible argument can be made that the extension "promote[s] the Progress of Science and the useful Arts" in that it provides owners of copyrights in old films an incentive to restore them. ${ }^{289}$ The extension also benefits American copyright holders who are seeking to derive copyright protection in EU nations, and this benefit can be seen as "promot[ing] the Progress of Science and the useful Arts." ${ }^{290}$ It can also be argued that a wealth transfer to the class of copyright holders achieves the Preamble's ends by increasing their ability to produce. Thus, if Disney earns greater profits because its copyright on Mickey Mouse lasts longer, it will be able to use those profits to fund the creation of new copyrightable material. Indeed, the legislative history of the CTEA stresses that "technological developments have significantly lengthened the commercial life of creative works." ${ }^{, 291}$ Whether the interests of individual authors or corporations are concerned, the CTEA represents a judgment that creators

286. Eldred v. Ashcroft, 123 S. Ct. 769, 794 (2003) (Stevens, J., dissenting).

287. Edward Walterscheid has made an argument along these lines with respect to whether Madison believed that the Copyright Clause limited Congress's power under the General Welfare Clause and whether he thought that Congress had the power to use means other than copyrights and patents to promote intellectual property. See Walterscheid, supra note 4, at 103-04. Walterscheid is not concerned, however, with how broad Congress's power was in the issuance of copyrights.

288. See Eldred, $123 \mathrm{~S}$. Ct. at 778 (rejecting the petitioners' argument concerning the meaning of "limited Times," and concluding that extending the period of copyright protection enjoyed by existing copyright holders for a finite term is consistent with the constitutional text).

289. See id. at 782; S. REP. No. 104-315, at 13 (1996).

290. See Eldred, 123 S. Ct. at 781-82; S. REP. No. 104-315, at 4-5, 7-10.

291. S. REP. NO. 104-315, at 16-17. 
of copyrighted works should "receive the benefit of increased marketability of their creations." 292

In our view, moreover, the most compelling justification for retrospective extension is an equitable one. The CTEA may simply reflect a dual congressional commitment to promoting both the progress of the arts and the equitable treatment of copyright holders. To promote future creation, Congress decided in enacting the CTEA to increase the incentives for creation by increasing the period of copyright protection prospectively. In this context, retrospective extension of the copyright period reflects equitable concerns: One class of copyright holders (the class of those who create after enactment of the statute) should not be treated better than another class (those who created before enactment of the statute). ${ }^{293}$

Opponents of the Act's constitutionality, however, have rejected such justifications. In making originalist arguments, the IP Restrictors and the Eldred petitioners ascribe to the Founders a deep antipathy to monopolies that is seen as informing the proper reading of the Copyright Clause. This appeal to a broad principle animating the Founders fails, however, because it focuses on one group of Founders to the exclusion of other groups. The IP Restrictors present the debate among the Founders about monopolies as one pitting Thomas Jefferson and George Mason (both deeply opposed to the creation of government monopolies) against James Madison (with his reluctant acceptance of a very limited class of monopolies). In seeing the political spectrum as running from Mason and Jefferson to Madison, however, the IP Restrictors and Eldred dissenters simply ignore the people who would later become Federalists after the party division with the Republicans.

The Federalists, in general, believed monopolies could advance the commonweal. ${ }^{294}$ As their deep commitment to the federally incorporated Bank of the United States demonstrates, Hamilton and other members of the Federalist Party did not share the deep fear of government-created monopolies that plagued the Republicans. Similarly, at the state level, the debate about the legitimacy and the scope of state-granted monopolies in fields such as banking, steamboat franchises, bridges, ferries, and canals was a debate between Federalists, who typically believed monopolies could

292. Id. at 17.

293. See Eldred, 123 S. Ct. at $780-81$.

294. On the competing views of Republicans and Federalists regarding the Bank of the United States, see Janet A. Riesman, Money, Credit, and Federalist Political Economy, in BEYOND CONFEDERATION: ORIGINS OF THE CONSTITUTION AND AMERICAN National IDENTITY 128 (Richard Beeman et al. eds., 1987). 
be an engine of economic progress, and Republicans, who typically viewed monopolies as vehicles for illegitimate creation of privilege. ${ }^{295}$

Thus, to the extent that the IP Restrictors, the Eldred petitioners, and the Eldred dissenters are claiming to discover principles generally shared by the Founders, they miss the mark because they are focusing on only the part of the political spectrum made up of those most hostile to governmentcreated monopolies. In making the assumption that the Founders feared monopolies as embodying corruption, these scholars and advocates ignore the political party that was dominant in the first decade after the Constitution was ratified. This is a one-sided history; it leaves out the other political party, with its very different view about monopolies. It would be like a study of modern American views on tax policy or abortion that saw the gamut of differences as running from Trent Lott to George W. Bush and ending there.

Even some future Republicans were more tolerant of state-created monopolies than the IP Restrictors contend. For example, Madison supported the Corporations Clause and an additional constitutional clause that would have allowed Congress to provide incentives to inventors, reflecting a preference for government economic favoritism under some circumstances. With respect to incorporation and intellectual property, Madison was willing to commit to majoritarian decisionmakers the determination of when monopolies or a bonus system to private actors would advance the public good, subject to constraints (such as the limited time provision) that themselves committed a substantial amount of discretion to the decisionmaker. This is not to say that Madison championed monopolies or that he had no concern about incentive schemes. But in these areas he was willing to leave the judgment to the legislative process.

Consider Madison's reply to the letter in which Jefferson attacked the Constitution's intellectual property scheme, which we have cited from above:

With regard to Monopolies they are justly classed among the greatest nuisances in Government. But is it clear that as encouragements to literary works and ingenious discoveries, they are not too valuable to be wholly renounced? Would it not suffice to reserve in all cases a right to the public to abolish the privilege at a price to be specified in the grant of it? ${ }^{296}$

295. On the Federalist and Republican debate about the legitimacy of monopolies of various types at the state level, see MORTON J. HORWIT, THE TRANSFORMATION OF AMERICAN LAW, 1780-1860, at 109-39 (1977).

296. Letter from James Madison to Thomas Jefferson (Oct. 17, 1788), in 1 THE REPUBLIC OF LETTERS: THE CORRESPONDENCE BETWEEN THOMAS JEFFERSON AND JAMES MADISON 17761790, at 562, 566 (James Morton Smith ed., 1995); see also LANCE BANNING, THE SACRED FIRE 
As this excerpt makes clear, Madison's view was not so limited as that of the IP Restrictors. He did not view the purpose of the Copyright Clause as limited to encouragement of future production.

To gain a more complete view of Madison's views on this score, there is a final body of evidence to consider. Sometime after leaving the presidency, Madison wrote a series of "detatched memoranda" that were not published until the twentieth century. ${ }^{297}$ These memoranda, a treasure trove for historians, contain his fullest justification for the Copyright Clause. Madison wrote:

Monopolies tho' in certain cases useful ought to be granted with caution, and guarded with strictness agst abuse. The Constitution of the U.S. has limited them to two cases, the authors of Books, and of useful inventions, in both which they are considered as a compensation for a benefit actually gained to the community as a purchase of property which the owner might otherwise withold from public use. There can be no just objection to a temporary monopoly in these cases: but it ought to be temporary, because under that limitation a sufficient recompence and encouragement may be given. The limitation is particularly proper in the case of inventions, because they grow so much out of preceding ones that there is the less merit in the authors: and because for the same reason, the discovery might be expected in a short time from other hands. ${ }^{298}$

This excerpt demonstrates that Madison was interested in a notion of reward for authors; he speaks of "recompence" and "compensation for a benefit" that could have been withheld. Also significantly, Madison's focus with respect to the "limited Times" provision is on patents, not copyrights. "The limitation is particularly proper," he writes, "in the case of inventions." 299 Justice Breyer places great reliance on this memorandum, quoting it extensively in his dissent as evidence that "Madison, like Jefferson and others in the founding generation, warned against the dangers

OF Liberty: JAMES MADISON AND THE FOUNDING OF THE FEDERAL RePUBliC 330 (1995) (explaining that Madison supported federal aid for a scientific expedition to determine compass accuracy); BRUCE W. BugBEE, GENESIS OF AMERICAN PATENT AND COPYRIGHT LAW 131 (1967) ("Although [Madison] identified patents and copyrights with monopolies ... he felt nevertheless that American conditions justified their retention as exceptions to a general evil."); John Larson, Wisdom Enough To Improve Them, in LAUNCHING THE EXTENDED REPUBLIC 244 (Maeva Marcus ed., 1996) (explaining that Madison broadly construed commerce power to allow surveying of post roads).

297. See Elizabeth Fleet, Madison's "Detatched Memoranda," 3 WM. \& MARY Q. 534 (1946) (providing the text of Madison's memoranda).

298. Id. at 551.

299. Id. 
of monopolies." ${ }^{300}$ But Breyer fails to quote the final sentence in the excerpt above, which indicates conclusively that Madison's concern was not principally with copyright, but with "inventions."

The "detatched memoranda" also suggest that, for Madison, the principal reason why intellectual property rights were to be for a "limited time" was not his fear of monopolies per se, but his fear of establishing the rights in such a way that they could not be revisited and ended by later majorities. Madison wanted to reserve to the federal government the power to "terminate [patents and copyrights] by paying a specified and reasonable sum [to the holder]," because "[t]his would guard against the public discontents resulting from the exorbitant gains of individuals, and from the inconvenient restrictions combined with them. ${ }^{, 301}$ Madison continued:

One objection to a Bank is that it involves a qualified monopoly; and the objection certainly has weight in proportion to the degree $\&$ duration of the monopoly.

Perpetual monopolies of every sort, are forbidden not only by the genius of free Govts, but by the imperfection of human foresight. ${ }^{302}$

These passages suggest no less than that the CTEA would be constitutional under Madison's vision. By focusing on "the imperfection of human foresight," Madison indicates that Congress should not have the power to vest an intellectual property right permanently. That is why the Constitution (in accordance with Madison's initial proposal) provides that copyrights and patents can only be for "limited Times." But periodic extensions of the right- - each for a "limited time" - is a different matter, and that is what the CTEA involves. The petitioners' concern-that Congress will simply extend the copyright period again and again and again-is not troubling if the concern behind the "limited Times" provision is that a single Congress should not be able to create an intellectual property monopoly that extends too far into the future. Thus, the evidence indicates that the notion of retroactive copyright extension is consistent with broad Madisonian principles as they bear on the scope of the Copyright Clause.

From the vantage point of originalism, however, more important than the views of one person (even when that person is Madison) is the fact that other Founders-indeed, it would appear, most Founders-interpreted the Constitution differently than Madison and read its grants of power more broadly. For example, while Madison thought a Corporations Clause was

300. Eldred v. Ashcroft, 123 S. Ct. 769, 803 (2003) (Breyer, J., dissenting). For the quotations from the memorandum, see Fleet, supra note 297, at 551.

301. Fleet, supra note 297, at 552.

302. $I d$. 
necessary for Congress to charter corporations, Rufus King argued in Philadelphia that the Clause should not be included in the Constitution because the explicit grant of the power was "unnecessary"303 and because an explicit statement that Congress had the power was politically dangerous. ${ }^{304}$ James Wilson, who favored the Clause, nonetheless thought that Congress already had the power under the Commerce Clause to create "mercantile monopolies." ${ }^{, 305}$ Moreover, despite the fact that the Constitution has no Corporations Clause, Congress in 1791 chartered the Bank of the United States (over Madison's constitutional objections).

The interpretive approach reflected in these views about incorporation would suggest that for many, and perhaps most, of the Founders, the Copyright Clause was a clarification of a congressional power already existing under the Commerce Clause, perhaps in conjunction with the Necessary and Proper Clause, rather than a vesting of a new power in Congress. The question then becomes how tightly the limits in the Clause were understood. Did they strip Congress of power that it would otherwise possess under other constitutional provisions? Or to put the question in terms of the challenge to CTEA: Did the Founders share Eldred's concern about the need for originality and compliance with the Clause's Preamble?

Early practice is at odds with Eldred's position. It suggests that the Founders did not narrowly construe Congress's power to create intellectual property. First, the first Copyright Act, passed in 1790, allowed for copyright protection for "maps" and "charts."306 This alone reflected a significant departure from the English practice that, according to the IP Restrictors, shaped American views. ${ }^{307}$ More importantly, protection for maps and charts reflects a nonliteral reading of the Copyright Clause. It is, to quote David Currie, "a rather generous if appropriate interpretation of the constitutional term "writings.",308

In addition, while the IP Restrictors read an originality requirement into the Copyright Clause, the protection for maps also reflects the fact that the threshold for originality was low. Indeed, this approach continued for a substantial period. As Jane Ginsburg has observed:

303. 2 FARRAND, supra note 254 , at 615.

304. $2 \mathrm{id}$. at 616 . King feared that a corporations clause would lead those who opposed government banks to oppose the Constitution. 2 id.

305. $2 \mathrm{id}$. Mason, the only other participant in the debate, did not think that the power to create monopolies was "implied" in the Constitution. 2 id.

306. Act of May 31, 1790, ch. 15, 1 Stat. 124.

307. IP Restrictors highlight the similarity between the first copyright statute and the English Copyright Statute. See, e.g., Brief Amicus Curiac of Tyler T. Ochoa et al. at 24-25, Eldred v. Ashcroft, 123 S. Ct. 769 (2003) (No. 01-618) [hereinafter Historian's Brief]. But the relevant English statute, the Statute of Anne, did not protect charts and maps. 8 Ann., c. 19 (1710).

308. David P. Currie, The Constitution in Congress: Substantive Issues in the First Congress, 1789-1791, 61 U. CHI. L. REV. 775, 827 (1994). 
[T] he concept of authorship and the basis for copyright protection underlying judicial decisions until the mid-nineteenth century seemed to focus on the labor, rather than the inspiration, invested in the work. No matter how banal the subject matter, if the author's work resulted from original efforts, rather than from copying preexisting sources, the author was entitled to a copyright. ${ }^{309}$

The Founders were quite comfortable with copyright protection as a reward once a low level of originality was fulfilled.

Second, the 1790 Copyright Act provided protection retroactively, a point that the majority stresses. ${ }^{310}$ It was thus not limited to providing an incentive for future works. Eldred's attorneys and Justice Stevens concluded that the 1790 copyright statute dealt with a unique situation inherent in creating a new national system. ${ }^{311}$ Nonetheless, Congress was still providing an economic reward for those who had already created. Thus, the 1790 bill indicates that the Founders thought the Copyright Clause consistent with retrospective copyright protection. ${ }^{312}$

It should be added that Madison appears to have approved of the 1790 copyright statute. The fragmentary notes that we have of the debates on the bill on February 1, 1790, indicate that Madison's participation was limited to the suggestion that the bill need not protect non-U.S. citizens since "[w]e mean to give encouragement to the citizens of America, greater encouragement. ${ }^{, 313}$ In other words, Madison did not raise constitutional objections to a bill that represented a broad construction of the Copyright Clause. In fact, no members of Congress raised such objections. Also significantly, the following year, Madison cosponsored a bill that would have amended the 1790 copyright statute "to increase the penalties ... [that] apply to maps and charts and to books of calculation."314 Despite the fact that maps and charts do not fall within a literal reading of the Clause's text, Madison clearly thought the Copyright Clause allowed Congress to protect them.

309. Ginsburg, Creation and Commercial Value, supra note 197, at 1874.

310. See Eldred, $123 \mathrm{~S}$. Ct. at 775 (noting that the 1790 Copyright statute applied "to existing works... and future works alike"); $i d$. at 772,778 ("History reveals an unbroken congressional practice of granting to authors of works with existing copyrights the benefits of term extensions.... [T]he First Congress accorded the protections of the Nation's first copyright statute to existing and future works alike.").

311. See id. at 795 (Stevens, J., dissenting).

312. It should also be noted that a leading historian of the early history of copyright has pointed out that the 1790 Act reflects an embrace of a monopoly theory of copyright, rather than a natural rights theory. See PATTERSON, supra note 271, at 200 (observing that a limitation of benefits to citizens and residents of the United States and a one-year statute of limitations is consistent with monopoly theory).

313. 12 DOCUMENTARY HISTORY OF THE FIRST FEDERAL CONGRESS OF THE UNITED STATES OF AMERICA 122 (Helen E. Veit et al. eds., 1994).

314. COPYRIGHT IN CONGRESS, 1789-1904, at 124 (Thorvald Solberg ed., 1905). The bill was not adopted. Id. at 125 . 
Finally, in the early years of the Republic, Congress three times passed statutes that extended the period of patent protection for individual patents. In 1808 and again in 1815, it extended the period of protection for Oliver Evans's steam engine. ${ }^{315}$ In 1809 , it extended the patent held by Amos Whittemore and William Whittemore, Jr., for a machine used in the processing of wool and cotton. ${ }^{316}$ In the Eldred majority opinion, Justice Ginsburg relied on these early extensions and the early case law that upheld or approved of renewed or extended terms. Ginsburg saw these extensions and judicial decisions as proof of the original understanding. ${ }^{317}$ In contrast, the IP Restrictors argued that these precedents were irrelevant since Congress was acting for particular equitable reasons. ${ }^{318}$ But, as previously noted, the retrospective aspect of the CTEA can also be justified on equitable grounds. ${ }^{319}$ The point demonstrated by these three private actsas well as by the 1790 copyright statute-was that the Founding generation believed that the Copyright Clause allowed retrospective copyright protection for works already created-precisely the issue that was at stake in Eldred.

Justice Stevens found these extensions irrelevant because the patents involved material that had fallen into the public domain. His dissenting opinion asserted that patent protection cannot under modern case law be extended to material in the public domain, and that the early practice, "therefore, provide[s] no support for respondent." 320 This assertion is problematic - the issue of whether material in the public domain can be protected is currently at stake in Golan. ${ }^{321}$ Even if modern case law is inconsistent with original practice, however, this merely suggests that modern practice is at odds with originalism, not that original practice is irrelevant to modern controversies.

Finally, it should be noted that, had the Supreme Court accepted the petitioners' originalist argument, the result would have been highly ironic. The Framers at Philadelphia rejected Madison's Corporations Clause, but Congress proceeded to exercise the power to charter with its incorporation of the Bank of the United States in 1791, and the Supreme Court soon

315. Act of Jan. 21, 1808, ch. 13, 6 Stat. 70; Act of Feb. 2, 1815, ch. 36, 6 Stat. 147.

316. Act of Mar. 3, 1809, ch. 35, 6 Stat. 80 .

317. See Eldred v. Ashcroft, 123 S. Ct. 769,779 (2003). The early decisions on which Justice Ginsburg relies are Evans v. Jordan, 8 F. Cas. 872 (C.C.D. Va. 1813) (No. 4564), aff'd, 13 U.S. 199 (1815), Evans v. Robinson, 8 F. Cas. 886 (C.C.D. Md. 1813) (No. 4571), and Blanchard v. Sprague, 3 F. Cas. 648 (C.C.D. Mass. 1839) (No. 1518).

318. See Historian's Brief, supra note 307, at 26-29; Tyler T. Ochoa, Patent and Copyright Term Extension and the Constitution: A Historical Perspective, 49 J. COPYRIGHT SOC'Y USA 19, 58-82 (2001).

319. See supra text accompanying note 293.

320. Eldred, $123 \mathrm{~S}$. Ct. at 799 (Stevens, J., dissenting).

321. See supra text accompanying notes 193-196 (discussing Golan). 
approved a broad congressional power in this area in $\mathrm{McCulloch}^{322}$ If Eldred's position had been embraced by the Court, the Madisonian proposal that was adopted - the Copyright Clause-would have conferred a very limited power on Congress. At the same time, however, Congress would have a broad power to incorporate pursuant to McCulloch, despite the fact that the Framers rejected Madison's proposal to grant such a power. This anomaly underscores the deep gap between the IP Restrictors' position and the original understanding.

\section{INTEllectual Property as CONSTItUTIONAL Property}

In the last Part, we argued that the originalist claims of the IP Restrictors, the petitioners in Eldred, and the Eldred dissenters echoed the originalist claims made by defenders of Lochner-era jurisprudence. We then translated the two critiques offered by historians of Lochnerian originalism to the context of the originalism of the IP Restrictors. We argued that the IP Restrictors' originalism, like that of Lochner-era jurisprudence, fails as a historical account. The IP Restrictors and the Eldred dissenters do not recognize the limited scope of judicial review as it was originally understood and misconceive the Founders' substantive economic views (as well as their views about the Copyright Clause itself). In this Part, we wish to draw another link between Lochner-era jurisprudence and the opinions of the IP Restrictors and thereby provide a second basis for challenging the IP Restrictors' understanding of the Copyright Clause.

Our focus here will be on the common attitude of the Lochner jurists and the IP Restrictors toward judicial review of economic legislation and their similar attempt to constitutionalize a particular policy vision. In critiquing this view, this Part seeks to place both Lochner-era jurisprudence and the IP Restrictors' constitutional jurisprudence in a larger context of constitutional structure and history. In our judgment, judges should engage in deferential scrutiny of economic legislation regardless of the type of economic legislation and regardless of the relevant constitutional clause.

\section{A. Eldred and the Political Process}

As previously discussed, the IP Restrictors have sought to constitutionalize a particular vision of intellectual property-one that celebrates the value of a rich public domain and that believes that intellectual property rights are of a limited utilitarian value and should be granted with reluctance. In Eldred, appellants built two arguments on this framework. First, they argued that retrospective extension of copyright

322. McCulloch v. Maryland, 17 U.S. (4 Wheat.) 316 (1819). 
legislation should be subject to heightened scrutiny to ensure an appropriate fit between the means used and the end sought to be achieved. Second, and in the alternative, they urged the Court to adopt a bright-line test under which any retrospective extension of copyright protection is unconstitutional. While their demand with respect to this contention is not one for heightened scrutiny per se, it is still a call for highly active judicial review and involves a greater restriction on congressional power than would be involved in a balancing test.

The Eldred petitioners' argument was based, in part, on the view that Congress is prone to act lawlessly: The petitioners contended that Congress, by repeatedly enacting extensions of copyright protection, would end-run the "limited Times" language of the Constitution. Their position also involved reading into the Constitution a series of conclusions that would limit congressional power and that are far from evident from the text: that intellectual property protections are illegitimate if a particular grant of protection fails to promote the progress of science, that there must be a quid pro quo in return for the grant of rights, and that "originality" should be understood in a very limited way. Most dramatically, appellants' position reflected aggressive judicial policing of congressional legislation because it involved taking from Congress a power that it has repeatedly exercised at least since 1831 and, indeed, even since 1808, if one includes private legislation. ${ }^{323}$ As a result, a type of congressional action that has a strong grounding in tradition would have been rendered unconstitutional.

\section{B. Lochner and the Historical Response to Economic Change}

In contrast to Eldred, Lochner involved a different constitutional provision-the Due Process Clause of the Fourteenth Amendment. ${ }^{324}$ The Lochner Court found that New York's statute establishing maximum hours beyond which bakers could not work was unconstitutional because it interfered with the employers' and employees' right to contract-a liberty interest of which the individual could not be deprived without due process of law. According to Justice Peckham, the state could interfere with the right to contract if it were doing so in the exercise of its police power, but the maximum hours legislation was not a valid exercise of the police power since it did not advance the safety, morals, or welfare of the public or the health of the bakers. ${ }^{325}$ Analytically, the Court's approach bears some similarity to the bright-line test advanced by Eldred's attorneys and adopted by Justice Stevens. Rather than employing a balancing test, the Lochner

323. See Eldred, $123 \mathrm{~S}$. Ct. at $778-79$ (discussing historical practice); supra text accompanying notes $127-128,313-316$.

324. See Lochner v. New York, 198 U.S. 45, 53 (1905).

325. Id. at $57-58$ 
Court was simply holding that the legislation fell outside the permissible scope of state powers. ${ }^{326}$

More fundamentally, however, the opinion in Lochner is similar to the position championed by Eldred's attorneys and the dissents in that both involve aggressive judicial review of economic legislation and both can be seen as reflecting the belief that an active judicial role is necessary to combat rent-seeking in the legislative process. Attorneys for Eldred made that argument explicitly and the Eldred Court's dissenters did so implicitly. Although, obviously, the Court in Lochner did not employ the modern terminology of rent-seeking, Justice Peckham's opinion embodies the view that the legislation limiting bakers' hours was simply a wealth transfer that benefited bakers at the expense of bakery owners. Justice Peckham wrote:

The law must be upheld, if at all, as a law pertaining to the health of the individual engaged in the occupation of a baker. It does not affect any other portion of the public than those who are engaged in that occupation. Clean and wholesome bread does not depend upon whether the baker works but ten hours per day or only sixty hours a week. $^{327}$

And, the Court concluded, simple benefit to the bakers' health was not a constitutional basis for the exercise of statutory authority. As Professor Hovenkamp has observed of Lochner:

Inequality of bargaining power between capitalists and laborers affected the distribution of wealth between the bargaining parties, but the Court saw no effect on anyone else. For example, Justice Peckham held that the bakers' hours statute in Lochner (1905) must fall unless the plaintiffs could show a relationship between the number of hours a baker works and the "healthful quality" of the bread he produces. ${ }^{328}$

The Court was thus both viewing the statute as a wealth transfer and concluding that a statute that produced a wealth transfer, without benefiting society as a whole, was unconstitutional, even if the legislature decided that legitimate reasons existed for aiding a particular group.

326. For further discussion, see Duncan Kennedy, Toward an Historical Understanding of Legal Consciousness: The Case of Classical Legal Thought in America, 1850-1940, 3 RES. L. \& SOC. 3, 6-8 (1980) (arguing that the defining trait of classical legal thought was concern with spheres of power); and William Michael Treanor, Jam for Justice Holmes: Reassessing the Significance of Mahon, 86 GEO. L.J. 813, 834-36 (1998).

327. Lochner, 198 U.S. at 57.

328. HERBERT HOVENKAMP, ENIERPRISE AND AMERICAN LAW, 1836-1937, at 201-02 (1991). 
Scholars such as Richard Epstein have advanced an alternate view of the type of rent-seeking at issue in Lochner. As Epstein observes of the statute at stake in that case, "Its basic purpose was not to protect these workers, but rather to insulate the unionized bakeries that employed workers in two ten-hour shifts against competition from nonunion firms that deployed their workers in single twenty-hour shifts, and thus were caught by the statute. ${ }^{, 329}$ The rent-seeking here is by one group of owners-the owners of unionized bakeries. The owners of the unionized shops were using the legislative system to benefit themselves at the expense of another set of owners-the owners of nonunionized bakeries.

From the time it was handed down, Justice Peckham's decision was criticized for constitutionalizing a policy vision. Justice Holmes's stinging dissent castigated the majority opinion on precisely these grounds:

This case is decided upon an economic theory which a large part of the country does not entertain. If it were a question whether I agreed with that theory, I should desire to study it further and long before making up my mind. But I do not conceive that to be my duty, because I strongly believe that my agreement or disagreement has nothing to do with the right of a majority to embody their opinions in law. ... The Fourteenth Amendment does not enact Mr. Herbert Spencer's Social Statics. ${ }^{330}$

As indicated by this language, the classic critique of Lochner is that the Court read into the Due Process Clause a substantive vision of governance that was not grounded in either the text of the Clause or its original understanding. ${ }^{331}$ There is a linkage between the view that Lochner was concerned with rent-seeking and the view that it embodied a substantive constitutional vision. Lochner can be understood as embodying both the position that the Constitution does not permit rent-seeking and the Court's vision of what types of legislation constituted impermissible rent-seeking as opposed to permissible legislation in the public interest.

329. Richard A. Epstein, Pennsylvania Coal v. Mahon: The Erratic Takings Jurisprudence of Justice Holmes, 86 GEO. L.J. 875, 884 (1998); see also Rebecca L. Brown, Constitutional Tragedies: The Dark Side of Judgment, in CONSTITUTIONAL STUPIDITIES, CONSTITUTIONAL TRAGEDIES 139, 142 (William N. Eskridge, Jr. \& Sanford Levinson eds., 1998) ("[S]ubsequent analysts... have demonstrated that the law at issue in Lochner, despite its guise as a health regulation, was probably a rent-seeking, competition-reducing measure supported by labor unions and large bakeries for the purpose of driving small bakeries and their large immigrant workforce out of business.").

330. Lochner, 198 U.S. at 75 (Holmes, J., dissenting).

331. See, e.g., James E. Fleming, Constructing the Substantive Constitution, 72 TEX. L. REV. 211, 211-13 (1993); Stephen A. Siegel, Let Us Now Praise Infamaus Men, 73 TEX. L. REV. 661, 691-93 (1995) (reviewing OWEN M. FISS, 8 HISTORY OF THE SUPREME COLRT OF THE UNITED STATES: TROUBLED BEGINNINGS OF THE MODERN STATE, 1888-1910 (1993)); Sunstein, supra note 212 , at $876-83$. 
What the petitioners sought to do in Eldred is similar to what the Court did in Lochner. As the previous Part argued, the original understanding did not support the petitioners' view of the Copyright Clause. The petitioners' textualist argument was better than their originalist argument, but countervailing textualist arguments are at least as strong. To the extent that the Preamble of the Copyright Clause is simply hortatory, the literal language of the remainder of the Clause would indicate that Congress can grant extensions if it chooses: An extension is for a "limited Time[]," and the constitutional text speaks in the plural, which suggests that a work can be protected for an additional time beyond the original term, if Congress so elects. ${ }^{332}$ Thus, one is not obliged to adopt Lessig's argument that "limited" in the IP Clause means the same thing as "limited edition print." Indeed, at oral argument, at least one Justice rejected the analogy as soon as Lessig made it; this Justice, unnamed in the official transcript but elsewhere identified as Justice Souter, noted that the idea of "the limited edition print depends basically on an implied understanding between the person who makes the print and the person who buys it, and the understanding is, you won't go beyond 100 , or whatever number you write." ${ }^{333}$ In contrast, under the Copyright Clause, there is no contractual analysis "between the writer and ... somebody representing the public domain." 334 Hence, as the Justice concluded, "[t]he analogy doesn't seem to work.",335

As a textual matter, moreover, the petitioners' best contention was to supplement the latter half of the Copyright Clause ("by securing for limited Times...") by drawing on its Preamble in some fashion as a limitation on congressional power. Even here, however, to the extent that appellants acknowledged film preservation as "promot[ing] the Progress of Science," but claimed that it fails as a justification for the statute because of the lack of fit between means and ends, they moved beyond the Constitution's literal language. In addition, as we have previously discussed, the statute can be seen as reflecting a determination that prospective extension promotes science, combined with a determination that current copyright holders should be treated as well as future copyright holders. ${ }^{336}$ Thus, retrospective

332. See EDWARD WALTERSCHEID, THE NATURE OF THE INTEllectUAL PROPERTY ClaUSE: A STUDY IN HISTORICAL PERSPECTIVE 272 (2002) (suggesting that the Framers used the plural in recognition of the English practice of patent extension and copyright renewal). For cases holding the introductory language simply hortatory, see Eldred v. Reno, 239 F.3d 372, 377-78 (D.C. Cir. 2001), aff'd sub nom. Eldred v. Ashcroft, 123 S. Ct. 769 (2003); Hutchinson Tel. Co. v. Fronteer Directory Co., 770 F.2d 128, 130-31 (8th Cir. 1985); and Schnapper v. Foley, 667 F.2d 102, 112 (D.C. Cir. 1981). But see Pac. \& S. Co. v. Duncan, 744 F.2d 1490, 1498-99 (11th Cir. 1984) (giving the Preamble legal significance).

333. Transcript of Oral Argument, supra note 91, at 24. For an unofficial transcript, see Berkman Ctr. for Internet \& Soc'y, Harvard Law Sch., at http://cubicmetercrystal.com/log/ eldred2.html (last visited Mar. 3, 2003).

334. Transcript of Oral Argument, supra note 91, at 24.

335. Id.

336. See supra text accompanying notes 289-293. 
extension would reflect a commitment to contributing to the progress of science but to doing so in a way that is equitable. This approach is also consistent with giving the Preamble legal force. ${ }^{337}$ An analogy can be drawn to the Commerce Clause area, where the Supreme Court has approved the constitutionality of application of statutes to facts that, viewed in isolation, did not constitute interstate commerce. ${ }^{338}$

Thus, the petitioners' originalist claims were weak and their reading of the constitutional text was nothing more than a plausible reading of a clause that can be understood in more than one way. Yet, neither textualism nor originalism alone drove Eldred's argument. The IP Restrictors are committed to a vibrant public domain, and they seek to read that commitment into the Constitution. Legislation that curtails the public domain is viewed as rent-seeking and unconstitutional. The dissenters advanced similar themes. The echoes of Lochner-the suspicion of the legislative process and the constitutionalization of a substantive vision-are strong.

The larger point to recognize here, however, is not simply that, had the petitioners prevailed, Eldred would have looked like Lochner. It is that there is a larger historical pattern that merits recognition. Lochner-era jurisprudence manifests a deep historical phenomenon concerning the relationship between economic change, government regulation, and judicial review.

This nation has witnessed on three occasions a three-stage response to dramatic economic change. In stage one, legislatures respond to economic change by enacting legislation. In stage two, courts employ new constitutional doctrine to review aggressively the new legislation. In stage three, courts ultimately retreat from that stance and embraced deferential review of economic legislation. Lochner simply provides the most familiar illustration of the way in which courts in this country have repeatedly adopted short-lived activism in times of economic transformation. The petitioners would have pushed the Supreme Court into commencing a fourth cycle. At the same time, consideration of these cycles suggests a rationale for the Court's opinion far more complete than the one the Court

337. Cf. Mitchell Bros. Film Group v. Cinema Adult Theater, 604 F.2d 852, 860 (5th Cir. 1979) (indicating that, even though protection of obscene works, standing alone, would not contribute to the useful arts, those works can be protected because Congress could decide "that the best way to promote creativity is not to impose any governmental restrictions on the subject matter of copyrightable works"), cert. denied, 445 U.S. 917 (1980). For further discussion of the Preamble, see 1 Melville B. NimMER \& DAVID NIMMER, NimMER ON CoPYRIGHT $\$ 1.03$ [B] (2002); and Walterscheid, supra note 4, at 389-90.

338. See, e.g., Perez v. United States, 402 U.S. 146 (1971) (holding that wholly intrastate activity could be criminalized pursuant to the Commerce Clause because of the cumulative effect on interstate commerce); Unitcd States v. Darby, 312 U.S. 100 (1941) (concluding that even in the absence of proof that sanctioned activity affected interstate commerce, the Commerce Clause was satisfied because the class of activities affected interstate commerce). 
adopted: The Court in Eldred properly deferred to Congress because our Constitution, viewed holistically, has come to embody deferential judicial review of economic legislation and because this is an appropriate result. ${ }^{339}$

\section{The Rise of the Corporation and the Contract Clause}

The first example of the historical cycle occurred in the early nineteenth century, and the prominent judicial decision that serves as the analogue of Lochner in that initial cycle was Dartmouth College v. Woodward. ${ }^{340}$ This case was decided in 1819 , at a time in which the business corporation was increasingly becoming a central vehicle for economic activity. The business corporation was a relatively recent innovation. In England and in the colonies, the corporate form had been used for charitable, quasi-public, and public institutions. ${ }^{341}$ In the late eighteenth and early nineteenth centuries, state legislatures had begun to sanction the use of the form for private commercial activity, where the corporation's immortality-in contrast to the typically limited duration of joint stock companies-made it an attractive device for fund-raising entrepreneurs. ${ }^{342}$ In 1780 , for example, there were seven business corporations. In contrast, between 1790 and 1800,295 corporate charters were issued. ${ }^{343}$

Although it involved an educational institution, a traditional form of corporation, rather than a business corporation, Dartmouth College presented the question of whether a legislature could alter the terms of the corporate charter. Chief Justice Marshall, writing for the Court, relied on the Constitution's Contract Clause to hold that it could not because corporate charters were contracts within the meaning of the Contract Clause. ${ }^{344}$ Even as Marshall so ruled, he acknowledged that " $[\mathrm{i}] \mathrm{t}$ is more than possible, that the preservation of [corporate rights] was not particularly in the view of the framers of the constitution. 3345

The Dartmouth College case was as important in its time as the Lochner decision would later prove to be. As Kent Newmyer has observed, "For the remainder of the nineteenth century, the Dartmouth College decision was a potent legal and ideological weapon for corporations who sought to defeat regulation and establish the ideological primacy of laissez-

339. Regarding the need for a holistic interpretation of the Constitution, see infra Section V.E.

340. 17 U.S. (4 Wheat.) 517 (1819).

341. See R. Kent Newmyer, John Marshall as a Transitional Jurist: Dartmouth College v. Woodward and the Limits of Omniscient Judging, 32 CONN. L. REV. 1665, 1667-68 (2000).

342. Id.

343. HORWITZ, supra note 295 , at $\mid 12$.

344. Dartmouth College, 17 U.S. (4 Wheat.) at 644.

345. Id. 
faire capitalism. ${ }^{346}$ Nonetheless, as the century progressed, the Court narrowed the scope of the Contract Clause in three critical ways that increased the ability of states to regulate economic activity.

First, in Charles River Bridge v. Warren Bridge, the Court took the position that state charters were to be strictly construed against the private party, an interpretive approach that meant fewer cases in which charters would be read to bar state regulation ${ }^{347}$ Second, the Court held that, while the state could not alter contractual duties, it could alter remedies. ${ }^{348}$ Third, it held that, in the exercise of its police power, a state could renounce contracts into which it had previously entered. Thus, in the leading case of Stone $v$. Mississippi, a state was permitted to ban lotteries after it had previously chartered a lottery company. ${ }^{349}$ " $[\mathrm{N}]$ o legislature can curtail the power of its successors to make such laws as they may deem proper in matters of police,", 350 the Court asserted. The twentieth century has seen even further cutbacks placed by the Supreme Court on the scope of the Contract Clause. The leading case here is Home Building \& Loan Ass'n v. Blaisdell, in which the Court held that, on police power grounds, a state could enact a debtor-stay law even though this statute was precisely the type that the Contract Clause was adopted to forbid. ${ }^{351}$

\section{The Modern Business Enterprise and Substantive Due Process}

The rise and decline of economic substantive due process-the doctrine at issue in Lochner-parallels the rise and decline of the Contract Clause. As Alfred Chandler has shown in his classic study, The Visible Hand, the first "modern business enterprises" were the railroads, and their takeoff period was the 1850 s and $1860 \mathrm{~s}^{352}$ After initially fostering railroad development through land grants and other means, states after the Civil War began to regulate railroads and their rates. Legal challenges to this system of rate regulation achieved prominence in the $1870 \mathrm{~s}$, approximately a decade before there were significant legal challenges to other forms of state regulation. ${ }^{353}$ Strong judicial review of state legislation first emerged in the

346. Newmyer, supra note 341 , at 1668 ; see also Gregory A. Mark, Comment, The Personification of the Business Corporation in American Law, 54 U. CHI. L. REV. 1441, 1441 (1987) ("The Dartmouth College decision defined the corporation for the American bar for much of the nineteenth century.").

347. 36 U.S. (11 Pet.) 420 (1837).

348. See, e.g., Bronson v. Kinzie, 42 U.S. (1 How.) 311 (1843).

349. 101 U.S. 814 (1879).

350. Id. at 818 .

351. 290 U.S. 398 (1934).

352. Alfred D. Chandler, JR., The Visible Hand: The Managerial Revolution IN AMERICAN BUSINFSS 81-121 (1977).

353. Stephen A. Siegel, Understanding the Lochner Era: Lessons from the Controversy over Railroad and Utility Rate Regulation, 70 VA. L. REV. 187, 188-89 (1984). 
context of railroad and utility regulation, and then the case law from these areas provided the template for subsequent judicial decisions involving other regulations. As Stephen Siegel has observed, "The constitutional dimensions of industrial regulation were almost always an application or extension of debates first joined and largely resolved in the railroad and utility context." ${ }^{354}$ Thus, substantive due process began, not with Lochner's review in 1905 of state regulation of bakers' hours, but with Reagan $v$. Farmers' Loan \& Trust Co. ${ }^{355}$ an 1894 railroad-rate regulation case. ${ }^{356}$

Lochner, rather than representing a departure, was consistent with the earlier case law in which the Supreme Court, grappling with legislative responses to economic transformation, had come to scrutinize that legislation closely under the Due Process Clause. Courts in Lochner and other cases looked at statutes to determine whether they were valid exercises of the police power, or legitimate health, safety, morals, or welfare regulations. If they found these statutes were not, the statutes were invalidated under the Due Process Clause. ${ }^{357}$ The reach of substantive due process spread as the reach of regulation spread, and the reach of regulation spread in response to ongoing economic change.

The Court's retreat from Lochner is, of course, a familiar story. ${ }^{358}$ The turning point is typically considered to be the 1937 decision West Coast Hotel v. Parrish, in which the Court upheld a state law establishing a minimum wage for women. ${ }^{359}$ In that case, Chief Justice Hughes observed, "[R]egulation which is reasonable in relation to its subject and is adopted in the interests of community is due process." ${ }^{~} 360$ Since 1937, the Supreme Court has not invalidated a single statute on economic substantive due process grounds. ${ }^{361}$

\section{The Welfare State and Due Process}

This cycle of activism in times of economic transformation occurred a third time as the Supreme Court grappled with the rise of the welfare state.

354. Id. at 189.

355. 154 U.S. 362 (1894).

356. See Siegel, supra note 353 , at 189 n.9. For another important early railroad case, see United States v. Terminal R.R. Ass'n, 224 U.S. 383 (1912). This path-breaking decision concerns both antitrust and the regulation of common carriers.

357. For further discussion of the case law, see Treanor, supra note 326 , at $831-40$; and Sicgel, supra note 210 , at 15-23.

358. See, e.g., Howard Gillman, ThE CONSTITUTION BESIEGED: THE Rise AND DEMISE of LOChNER ERA POLICE POWERS JURISPRUDENCE (1993). On popular reaction to Lochner, see Barry Friedman, The History of the Countermajoritarian Difficulty, Part Three: The Lesson of Lochner, 76 N.Y.U. L. REV. 1383 (2001).

359. 300 U.S. 379 (1937).

360. Id. at 391 . 2002)

361. ERWIn Chemerinsky, Constitutional LaW: Principles and POlicies 601 (2d ed. 
Goldberg $v$. Kelly, ${ }^{362}$ a 1970 decision, is the leading case involving a strong assertion of judicial authority. In Goldberg, the Court found that people who received welfare payments had a property interest in the continued receipt of such payments and that the constitutional requirements of due process required a trial-like adjudication before the payments could be terminated. Justice Brennan noted for the Goldberg Court, "It may be realistic today to regard welfare entitlements as more like 'property' than a 'gratuity.' Much of the existing wealth in this country takes the form of rights that do not fall within traditional common-law concepts of property.,, 363

Yet, again, the Supreme Court later retreated. Thus, in $O^{\prime}$ Bannon $v$. Town Court Nursing Center, the Court found that residents in a nursing home had no right to due process before the government ended payments to the nursing home. ${ }^{364}$ The Court concluded:

Whatever legal rights these patients may have against [the nursing home] for failing to maintain its status as a qualified skilled nursing home ... we hold that the enforcement by HEW and DPW of their valid regulations did not directly affect the patients' legal rights or deprive them of any constitutionally protected interest in life, liberty, or property. ${ }^{365}$

Without overturning Goldberg, O'Bannon evidences the Court's movement away from the former decision's activist approach. As a leading treatise on administrative law observes, "The courts have... turned away from the trial-type mode of due process prescribed in [Goldberg]."366

The retreat from the Goldberg adjudicatory model has also been less than jurisprudentially lucid, with a justified complaint being the "unprincipled and unpredictable decisions" by federal courts concerning due process. ${ }^{367}$ And Congress itself has acted in the specific area of the Goldberg decision-federal welfare law-by turning the Aid to Families with Dependent Children program into the form of block grants to states and by specifically announcing that it did not intend to create any entitlements for individuals. ${ }^{368}$

362. 397 U.S. 254 (1970).

363. Id. at 262 n.8.

364. 447 U.S. 773 (1980).

365. Id. at 790 .

366. ALFRED C. AMAN, JR. \& William T. MAYTON, ADMINISTRATIVE LAW 180 (1993).

367. RICHARD J. PIERCE, JR. ET AL., ADMINISTRATIVE LAW AND PROCESS 247 (1985). For a classic critique of Goldberg due process jurisprudence, see JERRY L. MASHAW, DUE PROCESS IN THE ADMINISTRATIVE STATE (1985).

368. Personal Responsibility and Work Opportunity Reconciliation Act of 1996, Pub. L. No. 104-193, 110 Stat. 2105 (1996). 


\section{Economic Legislation and Deferential Review}

Obviously, many will disagree with some or all of the decisions just surveyed in which the Court abandoned a strong position of judicial review. As previously noted, a new body of scholarship has emerged defending Lochner. ${ }^{369}$ And, at the same time, Goldberg has an iconic status for political progressives as a landmark triumph for social justice. ${ }^{370}$ Nonetheless, the principle of deference to legislative judgment in the economic arena is well-established, and there are two solid reasons that support it.

The first reason for deference is that judicial competence in this area is limited. Courts are poorly positioned to gather and assess the data needed to evaluate economic decisions, and, on top of this, constitutional law is a tool lacking in the flexibility to confront changing circumstances. Justice Black's dissent in Goldberg is a prominent example of this critique of a strong judicial role in the economic realm:

[T] he end result of today's decision may well be that the government, once it decides to give welfare benefits, cannot reverse that decision until the recipient has had the benefits of full administrative and judicial review, including, of course, the opportunity to present his case to this Court. Since this process will usually entail a delay of several years, the inevitable result of such a constitutionally imposed burden will be that the government will not put a claimant on the rolls initially until it has made an exhaustive investigation to determine his eligibility. While this Court will perhaps have insured that no needy person will be taken off the rolls without a full "due process" proceeding, it will also have insured that many will never get on the rolls, or at least that they will remain destitute during the lengthy proceedings followed to determine initial eligibility. ${ }^{37}$

As Justice Black's opinion suggests, judicial decisions in the economic realm are likely to have unintended consequences. Thus, the first reason why courts should defer to legislatures or Congress is that these bodies are better able to conduct wide-ranging fact-finding.

Similarly, if the Court guesses wrong about consequences, the very nature of constitutional adjudication makes it difficult to shift course. Thus, in his Goldberg dissent, Justice Black also wrote, "The operation of a welfare state is a new experiment for our Nation. For this reason, among

369. See supra note 329 and accompanying text.

370. See generally Symposium, The Legacy of Goldberg v. Kelly: A Twenty Year Perspective, 56 BROOK. L. REV. 731 (1990).

371. Goldberg v. Kelly, 397 U.S. 254, 279 (1970) (Black, J., dissenting). 
others, I feel that new experiments in carrying out a welfare program should not be frozen into our constitutional structure." ${ }^{, 372}$ And welfare legislation has of late proved, at both the federal and state level, to be an area of considerable change-whatever the merits of these innovations may ultimately be. ${ }^{373}$

The second rationale for judicial deference is the political process rationale associated most prominently with John Hart Ely. ${ }^{374}$ Under this approach, courts as a general matter should defer to majoritarian decisionmakers because, at its core, our system of constitutional government rests on majoritarian decisionmaking for its legitimacy. Only where the operations of the political process are flawed-because some participants are effectively barred from meaningful representation-should courts intervene. ${ }^{375}$ Under this approach, legislation involving discrete and insular minorities is the paradigmatic type of legislation warranting close judicial scrutiny. ${ }^{376}$ And economic legislation is the paradigmatic example of the type of legislation that courts should not scrutinize closely. Economic legislation is the product of trade-offs made by interest groups. Except in exceptional circumstances, courts should not upset the resulting bargainedfor deals. ${ }^{377}$

We offer this brief discussion of economic legislation and the Constitution for two reasons. First, we wish to point out a historical pattern that has recurred at the major points of economic transformation in our nation's history. In the face of economic change, legislatures have responded by doing new things. Confronting the rise of business corporations, they sought to change corporate charters. Confronting the rise of modern business enterprises that enjoy monopoly profits, they sought to regulate rates. Confronting the rise of the welfare state, they sought to preserve their freedom of action by retaining control over the conditions of

372. Id.

373. The area is one of continuing controversy. See, e.g., Nina Bernstein, Strict Limits on Welfare Benefits Discourage Marriage, Studies Say, N.Y. TIMES, June 3, 2002, at Al (describing research findings unanticipated by policymakers that welfare reform regulation might indirectly discourage women from marrying). For a selection of academic views, see THE FUTURE OF SOCIAL INSURANCE: INCREMENTAL ACTION OR FUNDAMENTAL REFORM? (Peter Edelman et al. eds., 2002).

374. Dean Ely's classic work setting forth his political process theory is JOHN HART ELY, DEMOCRACY AND DISTRUST: A THEORY OF JUDICIAL REVIEW (1980).

375. Thus, one of us has called for heightened judicial scrutiny of decisions concerning deployment of election technology where choices made by the state and by counties can affect equal access to the electoral franchise. Paul M. Schwartz, Voting Technology and Democracy, 77 N.Y.U. L. REV. 625 (2002).

376. Id. at $675-83$.

377. For Ely's discussion of economic substantive due process, see ELY, supra note 374, at 14-19. For application of his insights in the context of the Takings Clause of the Fifth Amendment, see William A. Fischel, Regulatory TAKINGS: LAW, ECONOMICS, AND POLITICS 120-24, 136-40 (1995); and William Michael Treanor, The Original Understanding of the Takings Clause and the Political Process, 95 COLUM. L. REV. 782, $855-87$ (1995). 
benefit payments. In the Eldred case, finally, Lessig pointed to the rise of the Internet as making copyright issues more urgent than ever before, ${ }^{378}$ and Justice Breyer's dissent similarly stressed the relevance of economic transformation. ${ }^{379}$

In the past, the Supreme Court has responded to legislative innovation by seeking to assert control through close judicial scrutiny of majoritarian judgments. Later, the Court ultimately retreated and adopted a deferential stance toward the majority's judgments in economic matters. Treating the Copyright Clause in isolation (or solely in conjunction with the First Amendment), the IP Restrictors have proceeded without regard for this history.

This relevant history should serve as a caution. It highlights a process that helps explain why so many now seek aggressive judicial review: As Congress grapples with changed economic circumstances-namely, the dramatic rise in significance of intellectual property in the nation's economy-many in the legal community feel it appropriate to rein in Congress and subject majoritarian decisions to close judicial scrutiny. At the same time, history suggests that any victories for aggressive judicial review will ultimately prove unstable precisely because they are countermajoritarian. As a result, the history of judicial review of legislation affecting property suggests a pattern that the Supreme Court should be aware of as it moves beyond Eldred to consider other intellectual property questions. The Court should ask whether it should trump democratic processes and bear the institutional costs of exercises of judicial review when historical precedent suggests that it will ultimately retreat from that assertion of authority. There is thus more wisdom to the Court's analysis in Eldred than appears on the face of the opinion.

This history is also significant for normative reasons. It highlights the fact that-with respect to a series of constitutional issues involving property - the Supreme Court currently employs a deferential standard in reviewing legislation. The history thus raises the question whether the same stance should be adopted under the Copyright Clause. A lively debate exists at present as to whether intellectual property should be treated, as a general analytic matter, as a form of property. ${ }^{380}$ At least in the context of constitutional theory, however, intellectual property merits the same treatment as other forms of property. Indeed, deferential treatment of legislation involving intellectual property is more appropriate than

378. Amy Harmon, Debate to Intensify on Copyright Extension Law, N.Y. TIMES, Oct. 7, 2002, at $\mathrm{C} 1$.

379. See supra text accompanying notes 16,177

380. Compare Stephen L. Carter, Does It Matter Whether Intellectual Property Is Property?, 68 CHI.KENT L. Rev. 715 (1993), with Frank H. Easterbrook, Intellectual Property Is Still Property, 13 HARV. J.L. \& PUB. POL'Y 108 (1990). 
deferential treatment of other forms of property, as consideration of the two factors that have been advanced to justify deferential judicial review of economic legislation indicates.

We begin with the issue of judicial competence. The judicial branch seems particularly ill-suited to carry out searching scrutiny in this area due to the technological nature of the area and the fact that manageable judicial standards are particularly elusive here. ${ }^{381}$ How does a court determine what a "limited time" is? How does a court determine what "promotes the Progress of Science and useful Arts"? By their very nature, these are classic legislative judgments.

Both Brandeis and Holmes warned of the limits of institutional competence in cases involving intellectual property. In his famous dissent in International News Service v. Associated Press, Justice Brandeis argued against judicial recognition of a quasi-property right in news on judicial competence grounds:

Courts are ill-equipped to make the investigations which should precede a determination of the limitations which should be set upon any property right in news or of the circumstances under which news gathered by a private agency should be deemed affected with a public interest. Courts would be powerless to prescribe the detailed regulations essential to full enjoyment of the rights conferred or to introduce the machinery required for enforcement of such regulations. ${ }^{382}$

Justice Holmes voiced similar concerns. In Bleistein $v$. Donaldson Lithographing Co., a case where the Court held that the copyright statute covered circus posters, Justice Holmes observed:

It would be a dangerous undertaking for persons trained only to the law to constitute themselves final judges of the worth of pictorial illustrations, outside of the narrowest and most obvious limits. At the one extreme some works of genius would be sure to miss appreciation. ... At the other end, copyright would be denied to pictures which appealed to a public less educated than the judge. ${ }^{383}$

381. Jane Ginsburg came to a similar conclusion regarding judicial competence shortly after the Supreme Court decided Feist. See Ginsburg, No "Sweat"?, supra note 197, at 378-79.

382. 248 U.S. 215, 267 (1918) (Brandeis, J., dissenting). Brandeis added, "Considerations such as these should lead us to decline to establish a new rule of law in the effort to redress a newly-disclosed wrong, although the propriety of some remedy appears to be clear." $I d$.

383. 188 U.S. $239,251-52$ (1903). Holmes noted, "Their very novelty would make them repulsive until the public had learned the new language in which their author spoke." Id. at 251. 
Holmes pointed to the etchings of Goya and the paintings of Manet as works of genius that could not have been sure of protection "when seen for the first time." 384

Concerns about judicial competence are particularly compelling to the extent that the IP Restrictors call for courts to subject intellectual property legislation to heightened scrutiny to determine whether a tight fit exists between means and ends. Thus, the Eldred petitioners argued that the Supreme Court could not find broad copyright extension to be merited given that the strongest justification for retroactive extension, in their view, was merely to encourage the restoration of old films. ${ }^{385}$ The IP Restrictors call for a type of heightened scrutiny that would require the Court to determine the nature of the incentives created by the statute and then to balance the resulting benefits against the statute's reach. The necessary analysis is one that courts are by their nature ill-suited to conduct in any fast-changing, technologically complicated area.

Justice Breyer was nevertheless ready in Eldred to carry out the kind of balancing that the IP Restrictors sought. As we have seen, his dissent found that the CTEA would cause great harm to the public sector and few benefits to authors. On the benefit side, he did the arithmetic and found "a $1 \%$ likelihood of earning $\$ 100$ annually for 20 years, starting 75 years into the future," to be "worth less than seven cents today." Breyer's advice to authors was to put "a few dollars into an interest-bearing account." 386 Implicit in this advice is a judgment by Breyer about how copyright law may or may not motivate authors-the only permissible motivation is one that is economically rational. It may be, however, that would-be authors of classic works, like most people, are motivated by irrational forces in their judgments. An entire new field of law and economics even looks at the widespread impact of "bounded rationality" on human decisionmaking. ${ }^{387}$ Suffice it only to say that authors may well not follow the same purely rational calculus as Breyer. Indeed, his analysis of the nature of the psyche of authors is precisely the kind of issue that, in the real world, judges are not well-situated to address.

384. Id.

385. Petitioners' Brief, supra note 34 , at $44-45$. For a more sympathetic reading of this policy ground for longer copyrights, see Landes \& Posner, supra note 21, at 490-91.

386. Eldred v. Ashcroft, 123 S. Ct. 769, 807 (2003) (Breyer, J., dissenting).

387. For a concise introduction, see Kreps, supra note 182, at 168-73. See also Cass R. Sunstein, Probability Neglect: Emotions, Worst Cases, and Law, 112 YALE L.J. 61 (2002). This body of theory has been used by legal scholars in the context of contract law, see Russell Korobkin, Inertia and Preference in Contract Negotiation: The Psychological Power of Default Rules and Form Terms, 51 VAND. L. REV. 1583, 1587-92 (1998), and privacy law, see Edward J. Janger \& Paul M. Schwartz, The Gramm-Leach-Bliley Act, Information Privacy, and the Limits of Default Rules, 86 MINN. L. REV. 1219, 1242-46 (2002); Paul M. Schwart, Beyond Lessig's Code for Internet Privacy: Cyberspace Filters, Privacy Control, and Fair Information Practices, 2000 WIS. L. REV. 743, 768-69. 
One should also note that the IP Restrictors' economic-utilitarian view of copyright is only one of several competing visions for this area of law. ${ }^{388}$ Moreover, significant differences are possible even within this perspective. Thus, Landes and Posner have recently argued that a system of unlimited renewals for copyright might increase the amount of intellectual property in the public domain. ${ }^{389}$ It is not necessary for our purposes, however, to pass on the merits of any of these challenges to the economics of the IP Restrictors. We wish only to note that judges are not well-suited to be arbiters for these kinds of policy and academic disputes.

To the extent that the Eldred petitioners sought a bright-line testunder which any retrospective extension of copyright was invalid - the manageability problem may seem less obvious. Nonetheless, the arguments underlying the bright-line test in this context will inevitably suggest the appropriateness of balancing tests in other contexts where a bright-line test is not so readily available. Consider again the arguments made by Eldred. (1) There must be a quid pro quo for the grant of intellectual property rights. (2) The grant must promote the progress of science and the useful arts. (3) Originaiity must be understood narrowiy. A finding in Eldred's favor on these grounds would have been hard, if not impossible, to cabin. Such a finding would have encouraged the review by other courts of other types of intellectual property legislation under heightened scrutiny. ${ }^{390}$

We have thus far argued that limited judicial competence weighs against heightened scrutiny in this context. Second, intellectual property issues frequently pit powerful economic actors against each other. As a consequence, the political process generally works well in this realm. As an example, consider the controversial area of proposed database legislation. This area pits powerful companies that have an interest in protecting their computerized data (such as eBay, Lexis, and Westlaw) against companies that have a powerful interest in free access to those data. ${ }^{391}$ These companies seem well-matched in terms of economic resources and likely political clout.

As a further example, content providers such as Disney are now promoting legislation to require that piracy detection systems be installed in electronic devices that play or transmit digital video or audio. This

388. For a concise overview, see ROBERT MERGES ET AL., INTELLECTUAL PROPERTY IN THE, NEW TECHNOLOGICAL AGE 2-20 (2d cd. 2000). Even within the utilitarian-economic perspective, moreover, more issues appear contested than settled. See id. at 18-20.

389. Landes \& Posner, supra note 21, at 517-18.

390. For example, among recently enacted statutes that might be subject to challenge using a heightened scrutiny test are those that grant protection for long-known orphan drugs, 21 U.S.C. $\S \S 360$ aa-360ee (2000), obvious boat hull designs, 17 U.S.C. $\$ 1301$ (2000), and music that has not been fixed in a tangible form, 18 U.S.C. $\$ 2319$ A (2000). For a discussion of these statutes, see Heald \& Sherry, supra note 4, at 1121.

391. See Ron Eckstein, The Database Debate, LEGAL TIMES, Jan. 24, 2000, at 16 (describing this tension in the context of real estate databases). 
legislation, sponsored by Senator Ernest Hollings, ${ }^{392}$ faces strong opposition, however, from high-tech companies. ${ }^{393}$ The high-tech companies of Northern California (Silicon Valley) do not invariably march in lockstep with the content providers of Southern California (Hollywood). ${ }^{394}$

Now, it may be argued that some companies are so large and have such a powerful interest in certain laws that the legislative process does not work very well when they are involved. In particular, one can anticipate that the IP Restrictors might flip the point being made here and respond generally to the arguments advanced in this Essay with a political process argument focusing on the difference between statutes such as the CTEA and those like the maximum hours statute at issue in Lochner. Lochner erected roadblocks in the path of legislatures animated by the interests of the majority and prevented them from passing laws that regulated corporations in the name of public welfare. The CTEA, by contrast, involved powerful interest group rent-seeking at the expense of the majority. Thus, the IP Restrictors might argue that courts should subject such rent-seeking legislation to more exacting judicial review because the legislative process has been corrupted.

An initial response to this argument is that the playing field is much closer to being level in the area of intellectual property in general than it is with respect to other economic legislation. While Lessig and the other antienclosure scholars have made a public choice critique of the CTEA, a similar and stronger analysis can be made of other areas in which Congress legislates, such as environmental law. ${ }^{395}$ The more fundamental point to recognize, however, is that the claim that legislation like the CTEA should be closely scrutinized because of process failures is a claim without an obvious limiting principle; this claim would lead to judicial review of breathtaking scope.

Classic process theories, such as Ely's, identify a very limited set of circumstances in which the political process fails and heightened judicial

392. Consumer Broadband and Digital Television Promotion Act, S. 2048, 107th Cong. (2002)

393. James Lardner, Hollywood v. High-Tech, BuSINESS 2.0, May 2002, at http://www.business2.com/articles/mag/0,1640,39428,00.html.

394. Jane Black, High Tech vs. Hollywood on Capitol Hill, BUS. WK., Apr. 18, 2002, at http://www.businessweek.com/technology/content/apr2002/tc20020418 2194.htm; Declan McCullagh, White House Cool to Hollings' Act, WIRED NEWS, Apr. 27, 2002, at http://www.wired.com/news/politics/0,1283,52145,00.html.

395. Jonathan Macey uses public choice theory to explain a pattern in which we have

a lot of environmental legislation... combined with significant influence by interest groups on the specific nature and implementation of the environmental programmes we observe. In other words, we will get a lot of environmental legislation, but it not only will be less effective than it otherwise could be, it also will serve to benefit certain interest groups at the expense of others.

Macey, supra note 57, at 173. 
scrutiny is appropriate. Ely's representation-reinforcement theory of judicial review is thus focused on the representation of minorities. ${ }^{396}$ Footnote four of Carolene Products - the ur-text of the political process movement-is similarly focused on the protection of "discrete and insular minorities. "397 The legislation at issue in Carolene Products, namely a federal statute barring the shipment of "filled milk," is arguably classic rent-seeking legislation. ${ }^{398}$ The Court nonetheless subjected it to deferential review because it was adopted by a legislative majority and because it did not harm the interests of a "discrete and insular minority." Under such a view, minorities receive special protection because they are cut out of the political process. However, classic process theories are not opposed to selfinterested legislation. Rather, they seek to protect those who are not allowed to join with others in pursuing self-interested deal-making.

If the IP Restrictors are to be understood as adopting a process theory, it must be a process theory of a very different type. Their view would be that, because of the economic power of certain corporations and because of the importance they attached to the CTEA, a congressional majority adopted a statute not in the majority's interest and that the Court should therefore closely scrutinize the resulting legislation. This is a formula that, if generally applied, would give courts a roving commission to overturn legislation that they deem not in the public interest. One does not have to be a cynic (or a public choice theorist) to recognize that powerful economic interests account for a great deal of legislation. The amount of congressional legislation and the amount of legislation adopted by states that could be analogized to the IP Restrictors' approach to the CTEA is astonishing. If courts aggressively review economic legislation that seems to favor powerful special interests, they must aggressively review muchand perhaps most-economic legislation.

A great deal of legislation is the product of logrolling: Groups or politicians obtain legislation that they care deeply about in return for their support of legislation that they mildly oppose or about which they are indifferent. Robert Burt has recently published a moving personal essay, going back to his time as a congressional staffer, on how logrolling (a senator's vote to break a filibuster traded for a highway in Alaska) helped the passage of the 1968 Civil Rights Act. ${ }^{399}$ For a more recent example of

396. See ELY, supra note 374 , at $135-79$

397. United States v. Carolene Prods. Co., 304 U.S. 144, 152 n.4 (1938).

398. See Geoffrey P. Miller, The True Story of Carolene Products, 1987 SUP. CT. REV. 397, 398. The statute under challenge in Carolene Products defined "filled milk" as "any milk, cream, or skimmed milk ... to which has been added, or which has been blended or compounded with, any fat or oil other than milk fat, so that the resulting product is in imitation or semblance of milk, cream, or skimmed milk." Carolene Prods. Co., 304 U.S. at 146 n.1.

399. Robert A. Burt, Liberals' Labors Lost, LEGAL AFF, Jan.-Feb. 2003, at 55. Burt also reports on an ironic aspect of the logrolling trade by Senator E.L. Bartlett of Alaska-at the last 
economic interests carrying the legislative day, consider the Homeland Security Act of 2002, which turned into a statute of more than 300 pages as additional titles, at least one entirely unrelated to the war against terrorism, were stuffed into it. ${ }^{400}$ This picture of lawmaking is not pretty, but the elements described are a ubiquitous part of the process.

Moreover, if logrolling is ubiquitous, a judicial focus on whether a particular piece of legislation is in the public interest will also be problematic. The difficulty is that the frame of judicial analysis is necessarily narrow while the political process, by its very nature, involves trade-offs. Participants enter into bargains with other participants in the process: A legislator may vote for things that she actually opposes in order to gain support for things that she cares about. As a consequence, a particular statute adopted by a state legislature or Congress may be one that the legislative majority would reject in the absence of bargaining. Nonetheless, legislators who would otherwise oppose the legislation gain enough from the "deals" they enter into so that they vote in favor of the legislation. At least arguably, the legislators are voting for an entire package of legislation that is in the majority's interest.

Even if a court were well-positioned to determine what the people can be said to really want, the focus in a case on a specific piece of legislation would cause the court to go astray - to miss the forest for the trees. The particular piece of legislation may not be one that the legislative majority really wants. Nonetheless, the entire package of legislation (only one piece of which may be before the court) is one from which the majority benefits. Process theories, by embracing deferential review, allow political actors the bargaining space they need. The heightened scrutiny of the IP Restrictors does not.

minute, Bartlett decided to vote against the filibuster free of the condition he negotiated (that his vote be essential to break the filibuster against the Civil Rights Act) simply because he decided that it was the right thing to do. Id. at 57-58.

400. Homeland Security Act of 2002, Pub. L. No. 107-296, 116 Stat. 2135. The last four sections of the Homeland Security Act of 2002 provide the "liability shield." $\S \S 1714-1717$. For a complaint against the shield as a corporate giveaway, see Homeland Security Bill Promotes Governmental Secrecy, Rife with Corporate Giveaways, CONGRESS WATCH, Nov. 21, 2001, at http://www.citizen.org/hot_issues/issue.cfm? $[D=426$. For support of the measure, see John Carey, Why Inoculating Big Pharma from Vaccine Lawsuits Makes Sense, BUS. WK., Jan. 13, 2003, at 38.

As part of the last minute negotiations around this bill, an agreement was reached within the GOP to remove the immunity for the vaccine manufacturers. This unrelated section provided retroactive tort immunity for pharmaceutical companies that produce certain vaccinations; the provision was sought after and obtained by manufacturers of childhood vaccines that are now facing future lawsuits because their products contain potentially harmful preservatives. It remains to be seen if this deal will hold. See ABC News, A Fragile Balance: Tension Between Security and Privacy Worries Some Observers (ABC television broadcast, Nov. 16, 2002) (noting that critics of the Homeland Security Act argue that it is "loaded down with projects that look suspiciously like old-fashioned pork barrel politics, while it's missing provisions that would seem to be vital to public safety"), available at http://abcnews.go.com/sections/nightline/Nightline/ n1021115_homeland.html. 
Logically applied, the IP Restrictors' position would lead to a deeply countermajoritarian approach to judicial review. The classic critique of Lochner is that the Court should not second-guess legislative judgments and, in the absence of clear constitutional restrictions, it should let majorities govern. The IP Restrictors' approach contains precisely the same flaws that its critics find in Lochner.

\section{A Robust Public Domain and the Proper Judicial Role}

Finally, we believe the federal judiciary-along with policy initiatives and nonconstitutional law-should play a role in drawing the borders between the public domain and copyright. In this Essay, we argue only for deferential judicial treatment of intellectual property legislation under the Copyright Clause. We do not advocate restrictions on a robust public domain. In policing the borders of the statutory "fair use" and "parody" exceptions, for example, the federal judiciary can do much to strengthen the public domain. It is through use of these doctrines, for example, that Disney should see limits drawn on its ability to make Sleeping Beauty, Snow White, Cinderella, and Pinocchio exclusively its own. Indeed, in an important article, Joseph Liu has recently proposed that time be used as an explicit factor by courts in their fair use analysis. ${ }^{401}$ As Liu explains, greater fair use should be permitted for Mickey Mouse than Harry Potter because of differences in their relative dates of creation. ${ }^{402}$

Policy initiatives and nonconstitutional law also have an important role to play in establishing the respective bounds of intellectual property and the public domain. For example, Lessig and other anti-enclosure scholars have developed ingenious policy proposals for strengthening the public domain. Some of the most important of these are being put forward by the Creative Commons, a nonprofit organization housed at Stanford Law School and supported by Harvard Law School's Berkman Center for Internet and Society ${ }^{403}$ The Creative Commons is developing a Web-based "intellectual works conservancy" based on the Software Foundation's GNU General Public License, which will help people either dedicate their works to the public domain or license them on terms more generous than those found in copyright. $^{404}$ As with a land trust, people will be able to donate their

401. Joseph Liu, Copyright and Time: A Proposal, 101 MICH. L. REV. 419 (2002).

402. Id.

403. For the website of this new organization, founded in the spring of 2002, see Creative Commons, at http://www.creativecommons.org/learn/aboutus (last visited Mar. 3, 2003). An emerging nonprofit organization in defense of the public domain is Duke University Law School's Center for the Study of the Public Domain. See Declan McCullagh, University To Challenge Copyright Laws, CNET NEWS.COM, Sept. 4, 2002, at http://news.com.com/ 2100-1023-956637.html.

404. Creative Commons, supra note 403. 
copyrights to be held in public trust. The Creative Commons may also seek to purchase important works to help guarantee their widespread availability and integrity.

As a further policy proposal, immediately after the Supreme Court issued its Eldred opinion, Lessig suggested a small tax on copyright owners that would be paid fifty years after publication of a work. ${ }^{405}$ This proposal would create a way of allowing easy identification of current copyright owners as well as those owners who do not oppose their work entering the public domain. ${ }^{406}$ We think that the intellectual works conservancy and Lessig's fifty-year tax have the potential to reduce transaction costs that may otherwise restrict the availability of certain copyrighted works.

The reasons for deferential review of economic legislation, then, fully apply to the review of legislation enacted under the Copyright Clause. There is, at the same time, no countervailing consideration that would warrant a different approach to intellectual property. In particular, while the grant (or denial or limitation) of copyright protection has consequences for speech, the petitioners' argument in Eldred concerning the Copyright Clause is not one that implicates free speech concerns. The Eldred appellants instead argued in essence that retrospective extension of copyright protection should be invalidated under the Copyright Clause as rent-seeking. As such, appellants invoked an economic critique of the statute (to the extent it operates retroactively), and it is therefore particularly appropriate that the Court responded as it typically responds when economic legislation is challenged: The Court deferred to the legislature.

\section{E. Constitutional Holism}

As a final matter, we wish to offer an observation regarding the methodology by which we have reached this judgment regarding deferential judicial review. Our point is not simply that the same arguments that justify deferential review of legislation when it is challenged under the Contracts Clause and Due Process Clauses also apply to the Copyright Clause. Rather, we believe that all the property clauses of the Constitution should be understood holistically and construed according to a coherent approach. A range of modern scholars, such as Charles Black, John Hart Ely, Laurence Tribe, Akhil Amar, and Vicki Jackson, ${ }^{407}$ have argued against

405. Lawrence Lessig, Protecting Mickey Mouse at Art's Expense, N.Y. TIMES, Jan. 18, 2003, at A17.

406. Id.

407. Charles L. Black, JR., Structure and Relationship in CONSTItutional law (1969); ELY, supra note 374, at 11-41; 1 LAURENCE H. TRIBE, AMERICAN CONSTITUTIONAL LAW 38-41 (3d ed. 2000); Akhil Reed Amar, The Supreme Court. 1999 Term-Foreword: The 
constitutional interpretation that treats clauses of the document in isolation. Their argument is a compelling one: The Constitution was adopted as a whole (and its subsequent amendments operate against the backdrop of that whole), and its various parts are most sensibly read if they are construed together. It is therefore significant to the proper interpretation of the Copyright Clause that judicial deference to economic legislation has become the norm in the interpretation of the Due Process Clause and the Contracts Clause. Unless a good reason exists to treat the Copyright Clause differently, the norms established in analytically similar areas should govern the intellectual property area as well. ${ }^{408}$

Thus, as this Part has shown, there is a second lesson suggested by Lochner that bears on Eldred. This Part has sought to use Lochner and its aftermath as evidence of a larger pattern manifested in American history. In periods of dramatic economic change, courts frequently assert the power to review legislation aimed at confronting this change, but ultimately retreat from this assumption of power. This cycle suggests that the Supreme Court was wise in Eldred not to create a new Lochner. After all, history suggests that, had it done so, sooner or later, it would have retreated from this aggressive assertion of judicial review. Moreover, there are sound jurisprudential reasons why the courts have ultimately opted for deferential review of economic legislation. Finally, honoring constitutional holism, the Constitution's property clauses should all be construed in similar fashion. Although the opinion in Eldred does not make a holistic argument, the

Document and the Doctrine, 114 HARV. L. REV. 26 (2000); Vicki C. Jackson, Holistic Interpretation: Fitzpatrick v. Bitzer and Our Bifurcated Constitution, 53 STAN. L. REV. 1259 (2001).

408. In addition to the constitutional provisions discussed in the text, an additional clause directly implicates property rights: the Takings Clause of the Fifth Amendment. By its nature, the Takings Clause is analytically distinct from the three Clauses discussed in this Part. The Contracts Clause, the Due Process Clause, and the Copyright Clause (to the extent that it operates as a limitation on, rather than a grant of, congressional power) all serve to limit govemmental action. In general, the Takings Clause does not operate as a limitation per se, but establishes a precondition for government actions of a certain type: If a taking occurs, there must be compensation. An enormous scholarly debate has taken place concerning the proper scope of the Takings Clause, but one of the authors of this Essay has argued that (in large part for reasons applied here with respect to the Copyright Clause) courts construing the Takings Clause should employ deferential scrutiny. See Treanor, supra note 377 , at 855-87.

There is one element of the Takings Clause that-rather than establishing a precondition for government action-simply establishes a limitation on such action: Government may take property only for a "public use." U.S. CONST. amend. V. Because it is a limitation on government action, this element of the Takings Clause is the aspect that is most similar to the various property Clauses discussed above. Under the relevant Supreme Court case law, it is clear that courts should defer to rational legislative judgments about what constitutes a "public use." See Haw. Hous. Auth. v. Midkiff, 467 U.S. 229, 245 (1984) (upholding government action because " $[u] s e$ of the condemnation power to achieve this purpose is not irrational"). Thus, the most analogous aspect of Takings Clause jurisprudence provides further support for the argument here that courts, in reviewing economic legislation, employ deferential scrutiny in determining whether that legislation accords with constitutional limitations. 
result in the case is strengthened immeasurably when the holistic perspective is considered.

The lessons of history, a political process theory of constitutional law, and constitutional holism all point toward deferential review of legislation enacted under the Copyright Clause. And deferential review is exactly the stance that Justice Ginsburg's opinion for the Court in Eldred adopts.

As we have noted, Justice Breyer in dissent asserts that his concern is with the statute's "rationality." ${ }^{409}$ According to Breyer, a three-part test should be applied to judging the CTEA:

I would find that the statute lacks the constitutionally necessary rational support (1) if the significant benefits that it bestows are private, not public; (2) if it threatens seriously to undermine the expressive values that the Copyright Clause embodies; and (3) if it cannot find justification in any significant Clause-related objective. $^{410}$

But this test creates, in reality, a heightened level of scrutiny, rather than the classic rational basis scrutiny that the Supreme Court applies in economic cases. Justice Breyer justifies his approach by noting that the CTEA "involves not pure economic regulation, but regulation of expression." 411 And the cases upon which he relies as precedential support for his "rational basis" review are not true rational basis cases. ${ }^{412}$ Although the Court was nominally applying rational basis review in them, it was, in fact, as Laurence Tribe has observed, making "covert" use of a higher standard of scrutiny because the cases involved "statutes creating distinctions among classes of residents based on factors the Court evidently regards as in some sense 'suspect' but appears unwilling to label as such." "413

409. Eldred v. Ashcroft, 123 S. Ct. 769, 802 (2003) (Breyer, J., dissenting).

410. Id.

411. Id. In Breyer's view:

[I]t is necessary only to recognize that this statute involves not pure economic regulation, but regulation of expression, and what may count as rational where economic regulation is at issue is not necessarily rational where we focus on expression--in a Nation constitutionally dedicated to the free dissemination of speech, Id. information, learning, and culture.

412. Justice Breyer observes that his examination of the CTEA's rationality is "less hard than precedent might justify," id., supporting this claim with citations to City of Cleburne $v$. Cleburne Living Center, Inc., 473 U.S. 432, 446-50 (1985) (invalidating a zoning ordinance that required a special use permit for a proposed group home for mentally retarded individuals), Plyler v. Doe, 457 U.S. 202, 223-24 (1982) (overturning a Texas law that prevented children of illegal immigrants from receiving free public education), and Department of Agriculture v, Moreno, 413 U.S. 528, 534-38 (1973) (overturning a statute that barred households with unrelated members from receiving food stamps).

413. TRIBE, supra note 2 , at 1445 . For the de facto suspect classes involved in these cases, see supra note 412 . 
Classic rational basis review - the standard of review that the modern court has applied in the economic realm-is, in contrast, strikingly deferential. As Erwin Chemerinsky has observed, "The Court has made it clear that economic regulation-laws regulating business and employment practices-will be upheld when challenged under the due process clause so long as they are rationally related to serve a legitimate government purpose. ${ }^{, 414} \mathrm{He}$ adds:

The government's purpose can be any goal not prohibited by the Constitution. In fact, it does not need to be proven that the asserted purpose was the legislature's actual objective. Any conceivable purpose is sufficient. The law only need seem a reasonable way of attaining the end; it did not need to be narrowly tailored to achieving the goal. ${ }^{45}$

This is the approach Justice Ginsburg applies in Eldred. Justice Ginsburg's majority opinion applies classic deferential review akin to the traditional standard applied in judicial review of economic legislation. Considering "whether [the CTEA] is a rational exercise of the legislative authority conferred by the Copyright Clause," Justice Ginsburg observes simply, "On that point, we defer substantially to Congress." This Essay shows why the deferential approach Justice Ginsburg assumes to be correct is, in fact, correct.

\section{CONCLUSION}

As intellectual property has become increasingly important to the national economy, a consensus has emerged among academics that courts should scrutinize congressional legislation closely under the Constitution's Copyright Clause. This Essay has challenged the academic consensus about the Copyright Clause and sought to offer a more robust defense of the result

414. CHEMERINSKY, supra note 361 , at 491 .

415. Id. For leading examples of this approach, see, for example, Usery v. Turner Elkhom Mining Co., 428 U.S. 1, 15 (1976); Ferguson v. Skrupa, 372 U.S. 726, 729 (1963); and Williamson v. Lee Optical, 348 U.S. 483, 487-88 (1955). In modern contract clause jurisprudence, the Court applies a test that is "very similar to traditional rational basis review," CHEMERINSKY, supra note 361 , at 501 , when it is evaluating claims of government interference with private contracts. See Energy Reserves Group, Inc. v. Kan. Power \& Light Co., 459 U.S. 400, 411-13 (1983) (providing a three-part test: (1) Is there "a substantial impairment of a contractual relationship"? (2) Is there a "significant and legitimate purpose behind the regulation"? (3) Is the law "reasonable... [and] of a character appropriate to the public purpose justifying the legislation's adoption"?). It should be noted that the Court applies a more rigorous standard when the government interference is with government contracts. See United States v. Winstar Corp., 518 U.S. 839, 897 n.41 (1996) (observing that under the Court's Contract Clause case law "complete deference to a legislative assessment of reasonableness and necessity" has not been deemed appropriate where the state is a party to the contract (internal quotation marks and citation omitted)). 
reached in Eldred than is reflected in the Court's opinion itself. In so doing, it has drawn on lessons gleaned from Lochner. Defenders of Lochner-era jurisprudence, like the IP Restrictors, claimed that their position was consistent with originalism, and the two movements' conceptions of the original understanding are quite similar. The IP Restrictors and the champions of Lochnerism both portray the Founders as constitutionalizing their opposition to special-interest legislation and monopolies. Subsequent historical research challenged Lochner-era originalism as inconsistent with the original conception of judicial review and as misconceiving the Founding generation's attitude toward economic regulation. This Essay drew on precisely these two lines of argument to challenge the IP Restrictors' originalism, and we have argued that the IP Restrictors' originalism is as flawed as the Lochner-era originalism that it echoes.

The second lesson concerns the constitutionalization of a vision of the economy. Lochner is widely regarded as having constitutionalized a policy view. We argue that the IP Restrictors are trying to do precisely the same thing. In Lochner, that attempt proved unsuccessful in the long run, as the Court reversed itself and adopted deferential scrutiny of economic legislation under the Due Process Clause. We suggest that this episode is simply the most familiar manifestation of a larger historical pattern. At times of economic change, the Court has repeatedly tried to constitutionalize an economic vision, and it has repeatedly retreated and adopted deferential scrutiny. The reasons for deferential scrutiny of economic legislation-reasons sounding in judicial competence and process theory-are equally applicable here. Moreover, a holistic reading of the Constitution suggests that the deferential scrutiny that courts now employ in reviewing economic legislation under clauses of the Constitution other than the Copyright Clause should be applied in interpreting that Clause as well.

The purpose of this Essay is not to refute the IP Restrictors' policy vision. And we certainly are not writing in defense of rent-seeking. Our judgment is that the IP Restrictors' vision is not the constitutional vision of the Founders. Moreover, we believe that concerns about judicial competence, respect for the majoritarian process, and the dictates of constitutional interpretation mean that the Eldred Court was wise not to constitutionalize the IP Restrictors' vision. When courts exercise the power of judicial review under the Copyright Clause, the proper attitude is one of deference. The approach the Court now typically applies when reviewing legislation affecting property rights should apply, as well, in the intellectual property realm. 